Discussion

Papers

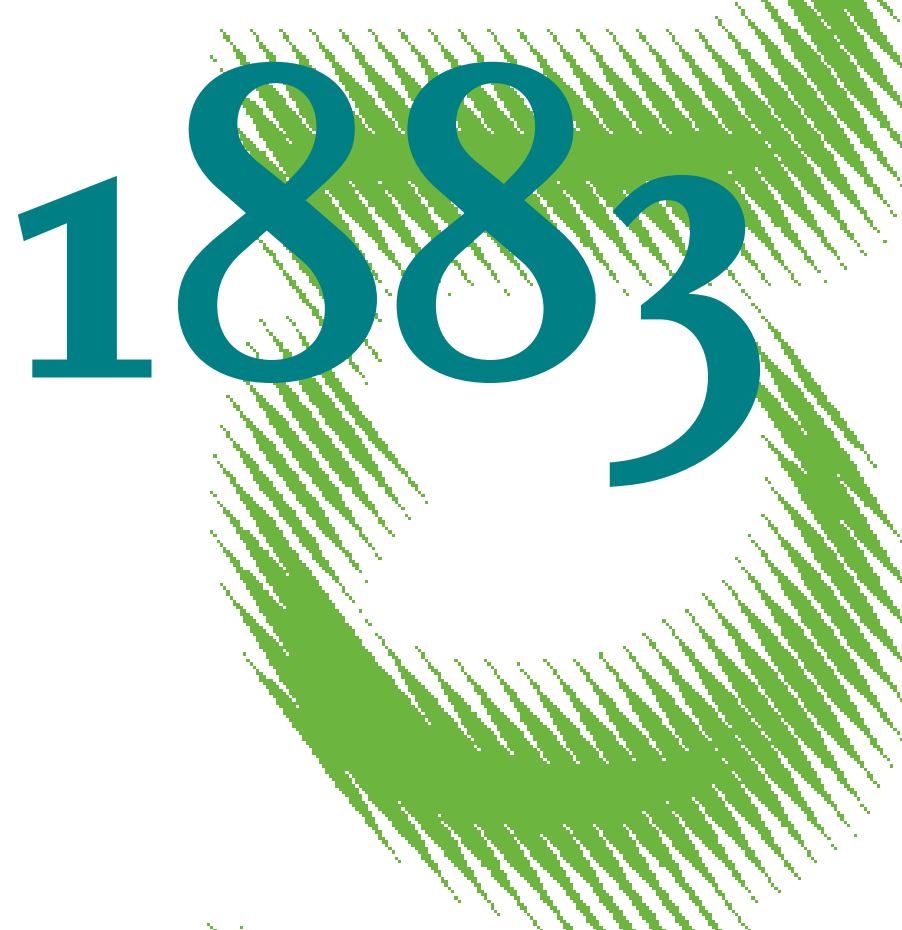

Nuclear Power as a System Good Organizational Models for Production along the Value-Added Chain 
Opinions expressed in this paper are those of the author(s) and do not necessarily reflect views of the institute.

IMPRESSUM

(C) DIW Berlin, 2020

DIW Berlin

German Institute for Economic Research

Mohrenstr. 58

10117 Berlin

Tel. +49 (30) $89789-0$

Fax +49 (30) $89789-200$

http://www.diw.de

ISSN electronic edition 1619-4535

Papers can be downloaded free of charge from the DIW Berlin website:

http://www.diw.de/discussionpapers

Discussion Papers of DIW Berlin are indexed in RePEc and SSRN:

http://ideas.repec.org/s/diw/diwwpp.html

http://www.ssrn.com/link/DIW-Berlin-German-Inst-Econ-Res.html 


\title{
Nuclear Power as a System Good Organizational Models for Production Along the Value- Added Chain
}

\author{
Ben Wealer $^{a, b^{*}}$ and Christian von Hirschhausen ${ }^{a, b}$ \\ ${ }^{a}$ Workgroup for Infrastructure Policy (WIP), Berlin Institute of Technology, Straße des 17. Juni 135, \\ 10623 Berlin, Germany \\ ${ }^{b}$ German Institute for Economic Research (DIW Berlin), Mohrenstraße 58, 10117 Berlin, Germany \\ *corresponding author: bw@wip.tu-berlin.de; bwealer@diw.de
}

\begin{abstract}
Due to its technical complexity, the co-production of electricity generation and nuclear weapons, and its high fixed costs, nuclear power is a particularly complex commodity, which poses unusual challenges for state economic (or industrial, defense, innovation etc.) policy. As in other sectors, the question arises here, too, of an adequate division of private and public responsibilities, in other words "competition and planning", taking into account knowledge aspects, incentive structures, transaction costs and a fair distribution of revenues and burdens. The nuclear sector requires an upstream system of a knowledge base, institutional and physical infrastructure (sites, transport, waste storage, etc.) and legal and institutional infrastructure. In this paper we apply the "system good analysis" developed by Beckers et al. (2012) and Gizzi (2016) to the nuclear power sector and identify ideal-typical organizational models for the value-added stages of the so-called nuclear front-end (mining, conversion, enrichment, fuel fabrication), constructing nuclear power plants, decommissioning and long-term storage as well as the respective interfaces between these stages. The main purpose of this overview paper is to assign tasks, rights and duties to organizations ("stakeholders") at the various stages of the value chain and to define the interface problems. We use an institutional economics approach, which focusses on the provisioning decisions and production between public authorities and private actors. In addition to a general overview, we focus on the back-end of the nuclear energy value chain, the decommissioning of facilities and the short- and long-term disposal of radioactive waste.
\end{abstract}

Keywords: nuclear power, organizational models, institutional economics, transaction cost, decommissioning, nuclear waste management 


\section{Content}

Abstract

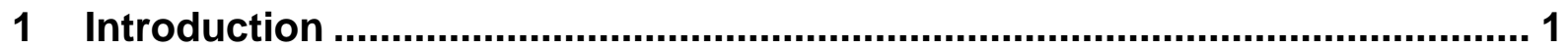

2 Methodological framework: Organization models for system

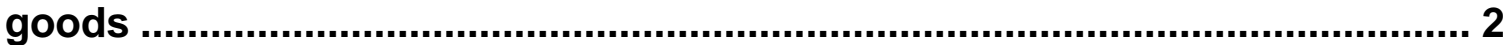

2.1 Institutional economic approach and overview............................................... 2

2.2 Key elements of the research framework.................................................. 5

2.3 Analysis, economic theories, and judgement values .......................................... 10

2.4 Provisioning - production - financing ..............................................................11

3 The system good nuclear power: A stylized description ........................... 12

3.1 The front-end: Mining and processing (A), enrichment $(B)$, and fuel

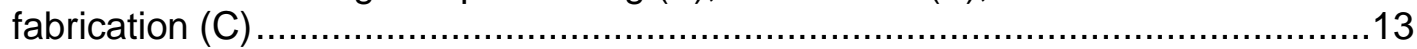

3.2 Nuclear power plant construction (D) ........................................................14

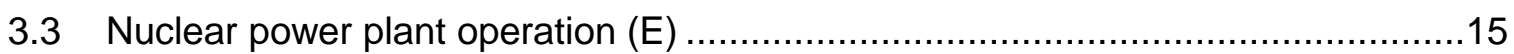

3.4 Decommissioning $(F)$.......................................................................

3.5 The back-end: Interim storage $(G)$, final disposal $(H)$, and reprocessing (I)

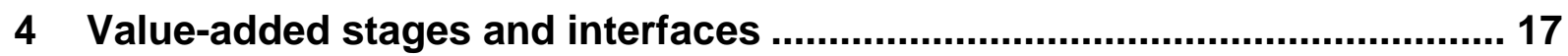

4.1 Nuclear front-end: From mining to fuel fabrication ..........................................17

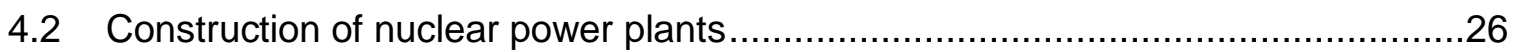

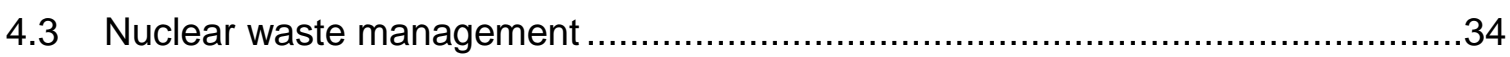

5 In-depth analysis: Reactor decommissioning .......................................... 40

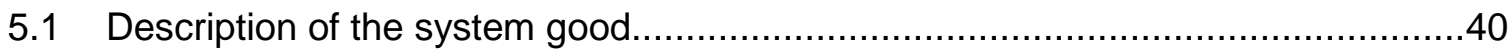

5.2 Mapping of the system good "decommissioning" in the analysis

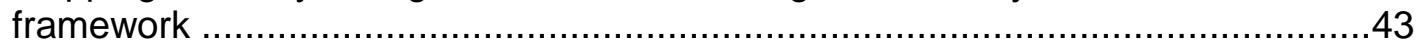

5.3 Three country cases studies and their organizational models ................................48

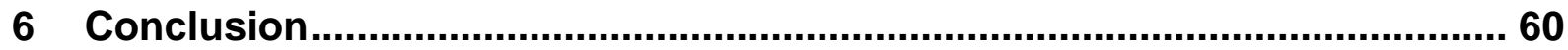

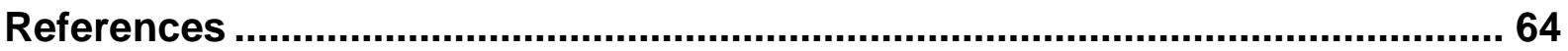




\section{Figures}

Figure 1: Central elements of the research framework ................................................................ 4

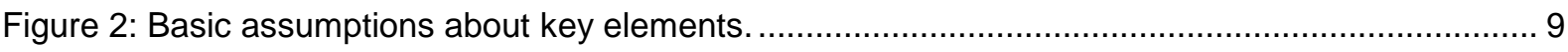

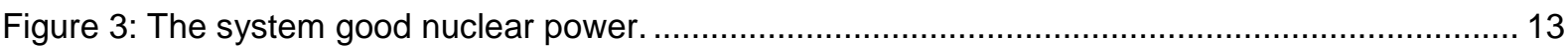

Figure 4: Technical system representation of the "front-end" for light water reactors......................... 17

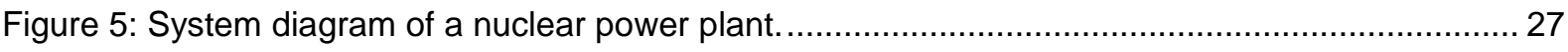

Figure 6: The nuclear fuel chain and generated wastes. ............................................................... 34

Figure 7: Overview of completed reactor decommissioning projects, 1953-2017. ............................. 43

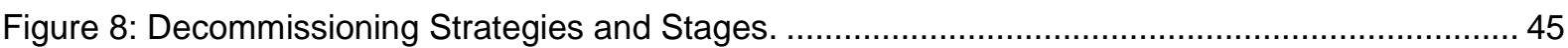

Figure 9: The Decommissioning Processes and the Interfaces to the Processes

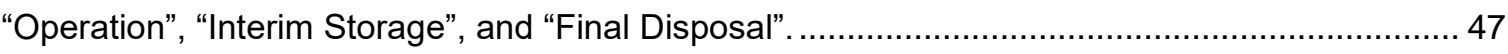

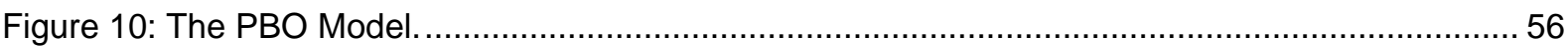




\section{Tables}

Table 1: Different categories of the economics of nuclear power: Time horizon and perspective.

Table 2: Processes and assets of the technical system "front-end".

Table 3: The ten biggest uranium mines, as of 2018.

Table 4: The top four uranium mining companies, as of 2018.

Table 5: Conversion plants and their capacity, as of 2018.

Table 6: Global enrichment capacity, operational and planned.

Table 7: Global LWR fuel fabrication companies and production capacity, ordered by capacity, in tons per year.

Table 8: Calculation of the $\mathrm{HHI}$ for construction projects by reactor vendor, as of late 2017.

Table 9: Calculation of the $\mathrm{HHI}$ for construction projects in late 2017, by supplier country.

Table 10: Forging companies for reactor pressure vessel production and their production capacity.

Table 11: Processes and Assets of the Technical System "Storage" and "Disposal". 37

Table 12: Decommissioned reactors worldwide, as of July, 2019. 42

Table 13: Processes and Assets of the Technical System "Decommissioning". 46

Table 14: Current Status of Reactor Decommissioning in the U.S. (as of May 2019). 49

Table 15: Decommissioned Reactors in the U.S. (as of 2019). 52

Table 16: Current Status of Reactor Decommissioning in Germany (as of May 2018). 58 


\section{Introduction}

Nuclear power, i.e. the energy released during the division (fission) or fusion (fusion) of atomic nuclei, is one of the fascinating phenomena of the technical and social sciences. In the $19^{\text {th }}$ century and at the beginning of the $20^{\text {th }}$ century, the focus was on basic scientific research (forces, radiation, etc.) and, since the 1930s, on applied engineering research (nuclear weapons, nuclear electricity). With the worldwide spread of nuclear power starting in the 1950s, social science issues were added, such as geopolitical applications of non-cooperative game theory (Nash 1950; Schelling 1960; Aumann 1972), political science issues of the governance of nuclear policy, as well as questions of locating sites for power plants and waste storage facilities (Brunnengräber et al. 2015).

Nuclear power also lends itself to a variety of original economic and institutional economic questions and has been researched from various sub-disciplines. However, the relatively small amount of economic literature is disproportionate to its complexity and social significance. With regard to the decision on the provision of nuclear power plants, there is consensus on a centrally planned, state decision, since decentralized, private actors have no economic interest in such a plant (Davis 2012; Joskow and Parsons 2012; D'haeseleer 2013; Wealer, Bauer, Göke, Christian von Hirschhausen, et al. 2019); production can then be carried out by the state (integrated) or by awarding contracts to private actors in connection with regulatory agreements (Barkatullah and Ahmad 2017). A detailed study on all aspects of decommissioning was developed by the Wuppertal Institute (2007). Since then, attempts were made to introduce competitive tendering in the decommissioning sector, e.g. in the UK, in the U.S. (Schneider et al. 2018, 2019) or Germany (Wealer et al. 2015; Volk et al. 2019). As of today, these approaches have not succeeded. In final disposal or long-term storage of nuclear wastes, too, a division of labor is emerging between central, state provision decisions and private participation in production (with full state responsibility for financing) (Brunnengräber et al. 2015, 2018; Wealer, Seidel, and von Hirschhausen 2019; Besnard et al. 2019).

In this paper, the organizational models for private or state-public action are classified along the valueadded chain of the nuclear industry. Organizational models in the sense of this contribution are institutional solutions for the production or provisioning of the complex good "nuclear power" or of individual subsystems of the value-added chain, which will be described in more detail in the following. However, the aim of this contribution is not to evaluate organizational models based on analysis parameters from economic theories (e.g. from New Institutional Economics: transaction costs, principalagent theory), but rather to perform a positive analysis of the organizational and supply models for the value creation stages of the nuclear sector. Of special interest in this paper is the question of competition in the different value-added stages. For this, we look at the governance structure of the involved companies (state, private, semi-private), their degree of vertical integration (Coase 1937; Williamson 1985), the market shares as well as the form of transaction, which can be done e.g. through the market or hierarchies, e.g. long-term contracts or vertical integration.

The remainder of this paper is organized as follows. Section 2 provides the methodological background, which leads to a comparison of alternative organizational models of system goods. Section 3 describes the system good "nuclear power" in general and provides thus a stylized representation of the sector and highlights the interfaces between the different stages as well as to the military sector. Building on 
this Section 4 then provides a positive analysis of the value-added stages "front-end" (from mining to fuel fabrication), "construction of nuclear power plants", and "back-end" (nuclear waste management) with respect to competition, the division of tasks between state and private actors, and the degree of vertical integration. In Section 5 an in-depth analysis of the decommissioning process, using three country cases studies (U.S., U.K., and Germany) is provided. Section 6 concludes. ${ }^{1}$

\section{Methodological framework: Organization models for system goods}

\subsection{Institutional economic approach and overview}

The nuclear power industry can be analyzed from different perspectives. Following Lévêque (2014, Chapter 1), Hirschhausen (2017, Chapter 3) has suggested to differentiate the analysis of nuclear power by $\mathrm{i} /$ the time horizon, and ii/ by the actor's perspective (see Table 1). With respect to time horizons, the very long-run external costs of nuclear power raises interesting economic and ethical issues, in particular with respect to the discount rate applied or whether a society should be allowed to produce nuclear power at all and leave the negative externalities (radioactive waste) to later generations (Schulze, Brookshire, and Sandler 1981). The long-run perspective mainly deals with the external costs in the case of an accident, e.g. the expected damages, the implied social costs thereof (i.a. Diekmann 2011; Meyer 2012; Kåberger 2019). The national perspective is helpful in analyzing the costs and potential benefits of developing nuclear power in a specific country but also for dealing with decommissioning nuclear power plants and nuclear waste management. The national costs also depend heavily on how responsibilities are divided up and framed along the value-added chain-in particular the downstream part, where issues of decommissioning and long-term storage of radioactive waste arise (Wealer, Seidel, and von Hirschhausen 2019; Besnard et al. 2019; Irrek 2019). The perspective of an operator or investor (box VII-IX) corresponds to a "private costs" approach, which the majority of the literature adopts. Social costs as well as costs for in the down-stream value-added stages are ignored and the only interest is if an investor can recover the investment expenses in the long-run (Rothwell 2016; D'haeseleer 2013). The short-run perspective asks whether a profit-oriented operator would want to continue to produce if, for instance, the price were higher than the short-run costs. The loss of operational competitiveness of nuclear power plants is gaining ground (Lovins 2013; Bradford 2013; Wealer et al. 2017; Clemmer et al. 2018).

Clearly, any analysis of the sector must focus on specific aspects of the possible options. In this context, this paper focusses on the national system cost perspective, analyzed through the lens of comparative institutional economics. We are mainly interested in different governance structures of the industry, i.e. "how it works" in reality, and thus provide a positive analysis of organizational models along the valueadded chain.

\footnotetext{
1 This paper is an output of a research program on nuclear power, carried out jointly between University of Technology (TU Berlin) and the German Institute for Economic Research (DIW Berlin). Different sections of the paper have been discussed previously in the contest of the World Nuclear Industry Status Report and the World Nuclear Waste Report, and thanks go to a large number of colleagues for commenting and providing suggestions. The usual disclaimer applies.
} 


\begin{tabular}{|l|l|l|l|}
\hline & $\begin{array}{l}\text { Very long-run (million } \\
\text { years, "eternity" costs) }\end{array}$ & $\begin{array}{l}\text { Long-run (investment } \\
\text { possible, } \sim 30-50 \text { years) }\end{array}$ & $\begin{array}{l}\text { Short-run (capacities fix, } \\
\sim 1-5 \text { years) }\end{array}$ \\
\hline (1) External costs & I: CE-VLR & II: $C_{E-L R}$ & III: CE-SR \\
\hline $\begin{array}{l}\text { (2) National system costs } \\
\text { IV: CN-VLR }\end{array}$ & V: CN-LR & VI: C N-SR \\
\hline $\begin{array}{l}\text { (3) Private costs for } \\
\text { operator/investor }\end{array}$ & VII: Co-VLR & VIII: Co-LR & IX: Co-SR \\
\hline $\begin{array}{l}\text { (4) Total (e.g. (1) }+(2) \\
\text { or: (1) }+(3)\end{array}$ & $\ldots$ & $\ldots$ & $\ldots$ \\
\hline
\end{tabular}

Table 1: Different categories of the economics of nuclear power: Time horizon and perspective.

Source: Hirschhausen $(2017,15)$.

The framework of "organizational models" was developed by the team around our colleague Beckers (Beckers, Kühling, and Klatt 2011) and the team on institutional economics and infrastructure management. The organizational models analyze governance structures of e.g. firms, state agencies, or non-profit organizations from an institutional perspective and hence emphasize the role of institutions as well as the importance of their design as a key determinant of economic development, implementation, and economic performance (North 1990). The framework was developed for the implementation or the supply of so-called "system goods". A system good is a complex good or service, which often includes the supply of a variety of services, which must be produced upstream or offered in parallel. This complex web of goods and services involves a variety of actors, which results in the need for coordination between these actors (Beckers, Gizzi, and Jäkel 2012, 1). 


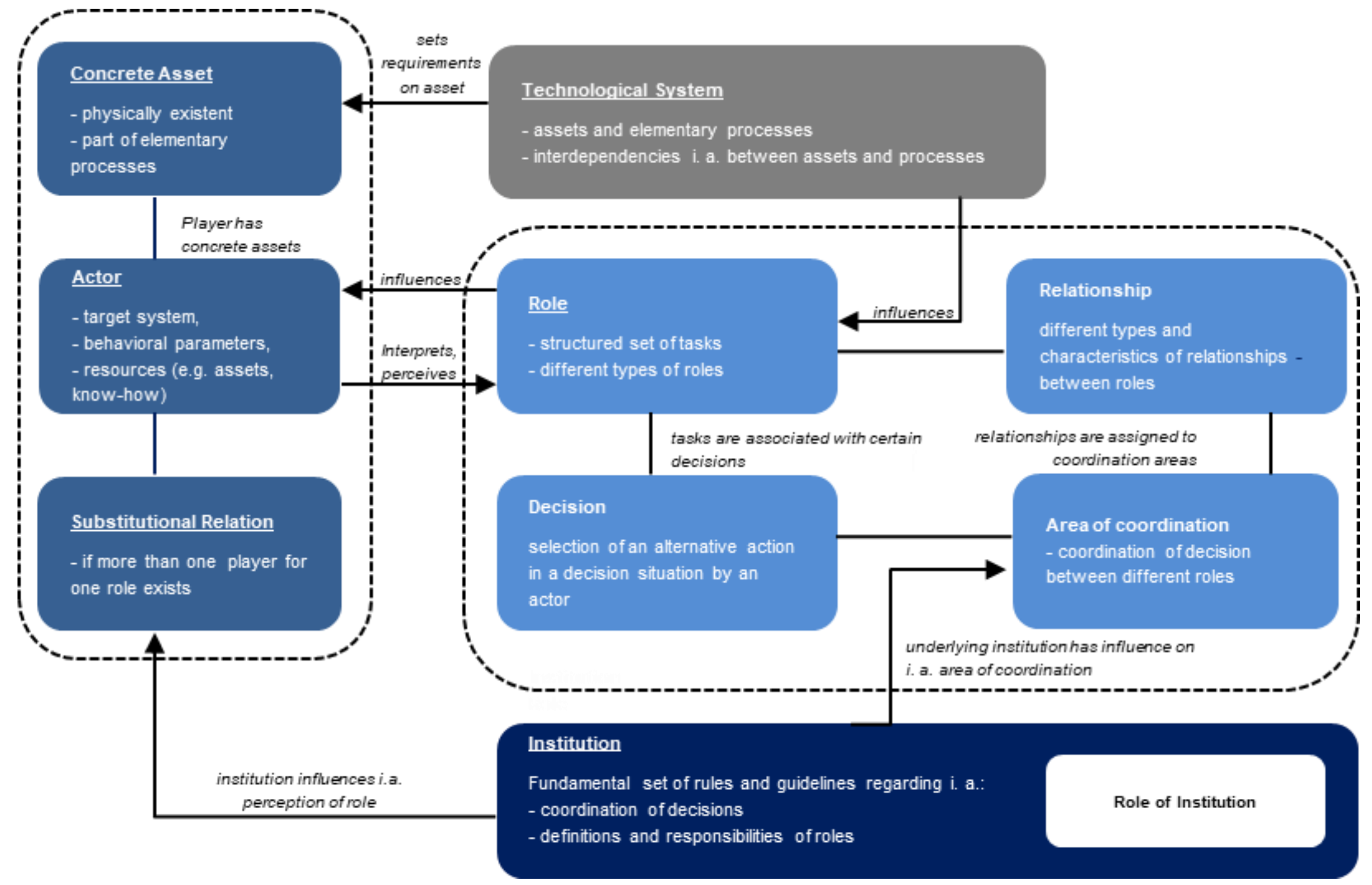

Figure 1: Central elements of the research framework.

Source: Beckers, Gizzi, and Jäkel (2012, 3). 
With this framework, different organizational models for system goods can be designed, analyzed and evaluated. This framework can be used for the positive analysis of existing organizational models and for the normative analysis of the design of organizational models. Key elements are the technical system, roles, tasks, actors, and institutions, which will be described in more detail below. Figure 1 gives an overview of the different elements of the research framework as well as the most important interlinkages. The technical system sets the requirements for the concrete assets and influences the roles, which are perceived by different actors, which all have different individual target systems, behavioral parameters, and resources. If different actors can fulfil the same role, a substitutional relationship emerges. Each role has a structured set of tasks, which are associated with certain decisions. Different roles can be connected through relationships, which are assigned to coordination areas, where decisions between different actors are coordinated. ${ }^{2}$

An important aspect of the framework is the identification of critical coordination needs; therefore, institutions play a major role in the framework, as they can influence not only role perceptions and the number of players but also the areas of coordination. As part of the analysis of specific organizational models, the values analysis parameters for an organizational model are determined. For the determination of these values, suitable economic theories, which allow statements about the value of the considered parameters, are to be used. To compare different organizational models with the aim of creating a ranking, a comparative evaluation of organizational models must also be carried out. This includes evaluations (i.e. subjective statements about the advantageousness of states) with respect to certain evaluation criteria. Such a comparative assessment can, for example for cost-based criteria, be relatively undisputed (lower costs are better than higher costs). However, for instance in the case of criteria relating to distributive effects, it may differ due to heterogeneous preferences (under which circumstances is one distribution "better" than another?).

\subsection{Key elements of the research framework}

\subsubsection{Technical system}

Central technical characteristics of the system good are represented in the technical system consisting of the two technical elements: elementary processes and assets. Both technical elements are needed in order to offer the system good. "An (elementary) process is always accompanied by a change of matter, information or energy in a material, spatial or temporal dimension" (Beckers, Gizzi, and Jäkel 2012, 4 (our translation)).

In general, it is useful to distinguish between the following processes in these three dimensions: transformation processes (i.e., material and temporal change, as in production processes), transfer processes (spatial and temporal change, as in transport or handling processes), and storage processes (temporal change). These elementary processes are carried out with the help of assets or other technical goods, which can be subdivided into short-lived consumer goods or durable commodities. An important aspect of describing both elements of the technical system in detail is first the identification and second the description of interdependencies between the different elements. If interdependencies exist, the

\footnotetext{
2 This sub-section is taken from the German text by (Beckers, Gizzi, and Jäkel 2012).
} 
interfaces of the corresponding assets must be designed. The following characteristics and details may be relevant: complementarity, compatibility, interoperability, substitution, specificity (for further details, see Gizzi 2016, 13-14). Gizzi $(2016,13)$ assigns the technical system to the sector model, which includes some information on the demand for this good as a second element. The demand allows a differentiation from the following roles and actors involved in the supply.

\subsubsection{Tasks, roles, and relationships}

In order for the system good to be offered, tasks must be fulfilled. A structured bundle of tasks can be assigned to different categories of roles. Gizzi $(2016,14)$ assigns the roles and tasks to the decision model. The offer of a service or good goes along with the securing of a continuous availability of this service or good and thus does not represent the one-time offer of a single piece, but the offer of several sequentially or parallel created "single pieces". To offer a good or service, certain phases must be undergone; it is therefore advisable for the implantation of system goods, to distinguish between the research and development phase, the planning phase, the construction phase, and the actual offer phase of a good or service (Beckers, Gizzi, and Jäkel 2012, 5-6). Either the bundle of tasks of a role can be assigned to the mentioned phases, or tasks can be assigned to different task complexes. Different types of roles can be defined based on the service offered by a role, which is associated with a certain bundle of tasks:

- The role type offering of a material good includes the responsibility for the offer (especially for production) of a material good (e.g., the offer of waste disposal casks).

- This good can be an asset that must in turn be made available for permanent use. The tasks associated with the provision of an asset are assigned to the role category provision of asset (for example, provision of road network).

- The role type offer of elementary process primarily comprises the combined use of assets to perform elementary processes (e.g. offer transport or offer handling).

- The offer of service role type primarily comprises the coordination of various elementary processes in order to assemble processes that are more extensive from these (for example, offer multimodal forwarding services).

If there is an interdependence between the services offered by two roles, a relationship between the two roles exists. Based on ideal-typical constellations in which services can be related to each other, Beckers et al. (2012) identify the following relationship categories:

- An ordering relationship exists between a role that requires a service and a role that offers this service.

- A time-complementary relationship exists between roles that are connected by sequentially linked (transport or transformation) processes.

- Material-complementary relationships exist between roles whose services must be utilized simultaneously from the user's point of view.

- A spatially complementary relationship exists between roles if they offer the same materially defined service in different areas and if the services offered in the different areas are required sequentially or in parallel. 


\subsubsection{Decisions and areas of coordination}

The tasks assigned to a role go hand in hand with certain decision-making situations and the concrete decisions that arise from them. Complex decision-making situations are often characterized by a large number of decision alternatives as well as by decision-theoretical uncertainty, i.e. by more than one possible future state of the environment. In addition, a complex decision-making situation can be characterized by interdependencies between individual decisions. In this case, the result of a decision depends on at least one other decision. Interdependent decisions can on the one hand be assigned to two different roles, resulting in a coordination area. The coordination areas existing between two roles can be assigned to the relationship existing between these two roles. On the other hand, interdependent decisions can also exist within roles, for example in the form of interdependencies between strategic decisions in the planning phase and operational decisions in the offering phase of a service. Coordination areas and their structuring, but also the coordination of interdependent decisions within a role, constitute the core of the research approach.

\subsubsection{Actors, substitute relationships, and concrete assets}

Actors carry out actions and make decisions regarding these actions. Players can take different forms, they can be an individual or an organizational unit; they can be described using different degrees of abstraction. ${ }^{3}$ Players take over one or more roles and make the decisions associated with the tasks assigned to these roles. All players are characterized by an individual target system; a private company operates in a different manner than a public agency, the former has profit-oriented targets, while the latter has more public economic oriented target systems; they also have different behavioral parameters (e.g. risk attitude). Both, the target system and the behavioral parameters, have a strong influence on decision-making and the willingness to cooperate in various areas of coordination.

Actors are also equipped with certain resources, which can be generally divided into asset resources (in the form of concrete assets) and other resources (e.g. know-how). If an actor wants to fulfill a certain role, his available resources must meet the requirements of the role. If an actor ex ante does not yet have the required resources, they can also be built up in the course of performing a role. In addition, the available resources held by a specific actor must meet the requirements of the technical system.

A role can be performed by several actors at the same time, in this case a service is offered in parallel by several actors. The number of which can be a result of market processes (monopoly, competition) or can be influenced by external specifications. In the case of multiple possible players, substitutive relationships arise between these actors. Contrary to the other relationships, described above, this relationship is structurally different, as it cannot exist between roles but only between players. Substitutive relationships can be accompanied by a coordination of decisions between the actors with regard to certain areas of coordination. For example, players linked by substitutive relationships could agree on the use of a uniform standard or on the pricing of services.

\footnotetext{
3 For instance, a concrete company that assumes the role of a nuclear reactor supplier (such as GE or Westinghouse) could be described more abstractly as nuclear reactor vendor, or even more abstractly as an industrial company.
} 
In addition to the number of actors, information can also be provided on the quantities of services offered by each actor (in terms of quantity). The information can refer either to relative (market) shares or additionally to absolute quantities. Such an indication, for example, can make it possible to take account of the distribution of power between actors. It is often the case that the number of actors who are generally suitable for the performance of roles is of particular importance because of their resources, as this can, for example, reflect aspects of potential competitive pressure.

\subsubsection{Institutions}

There is currently no basic definition of the term "institution" in economics (Furubotn and Richter 2005) but a broad consensus: Ostrom (2005) describes institutions as "prescriptions that humans use to organize all forms of repetitive and structured interactions". North (1990) defines institutions as "the rules of the game in a society" and as "humanly devised constraints that shape human interaction". Williamson (2000) sketches four levels of social analysis for institutions: The first level is the social embeddedness level, here institutions are represented by informal institutions (e.g., customs, traditions, norms, or religion). The second level is referred to the institutional environment with formal rules (e.g., property rights, constitutions, laws); this is what Williamson calls the "formal rules of the game", where economics of property rights and the positive political theory are the used tools for analysis. The institutions of governance are located at the third level and represent "the play of the game", here contract law, and as all contracts are unavoidably incomplete (Hayek 1945). Transaction cost economics and the general governance structures (e.g., markets, firms, hybrid, regulation etc.) play the major role at this level. The fourth and final level deals with resource allocation and employment, here prices, quantities, and incentive alignments play the central role, this level corresponds to neoclassical economies and agency theory (Williamson 2000, 597-600).

Beckers, Gizzi, and Jäkel $(2012,11-12)$ classify rules according to the following characteristics: i/ formal (e.g., laws, ordinances) and informal (e.g., customs, traditions) rules; ii/ according to the scope of application (e.g., local, (inter)national, supranational, or even company-internal rules) or iii/ according to the level of regulation (e.g., constitution, overarching laws such as the civil law or special laws). In the following, institutions are predominantly discussed in the form of rules, which correspond to the level two and level three institutions described by Williamson (2000). Rules structure and limit the actors' scope of action. Furthermore, role perception rules and coordination rules play an important role, especially in the analysis of system goods. The former can define, among other things, which actor is allowed to perform a certain role or which requirements an actor has to meet in order to perform the role. ${ }^{4}$ Role perception rules can also define the number of possible actors per role. Coordination rules can come into play if there is an interdependence between two decision-making situations. Thus, a coordination or harmonization of decisions between roles can be addressed. With regard to the supply of system goods, so-called role performance rules play an important role. A role performance rule can on the one hand define which prerequisites an actor has to fulfil in order to be allowed to perform a certain role. Licenses or permits can check the fulfilment of such prerequisites. On the other hand, role

\footnotetext{
${ }^{4}$ Compliance can be verified, for example, through approvals or certification.
} 
performance rules can determine the permitted number of actors per role, which is often determined within the framework of licensing.

If there is an interdependence between (at least) two decision-making situations, coordination of the decisions made with respect to these decision-making situations may be advantageous or even necessary. Coordination can be achieved through rules of coordination that address the coordination or harmonization of decisions between roles. Ideally, a distinction can be made between fully centralized coordination rules (e.g. through laws such as the Transport Services Act) and fully decentralized coordination rules (e.g. through individual negotiations between private companies and any resulting long-term contracts). Coordination rules are often at the forefront of investigations into the supply of complex system goods.

\subsubsection{Concluding overview and procedure for applying the framework}

Key elements of the research framework are the technical system, the actors (e.g. persons, organizations), their assets and roles, and the institutions. The actors have their own goals and characteristics and are expected to assume roles; the latter are bundled tasks or subtasks within the transformation process. Roles can be organized according to their bundle of tasks or according to the particular transformation phase into which they fit. The nature of all these elements, their abilities and goals, and the complexity of the technical system create mutual interdependencies, which need coordination. An important part of the framework are the institutions; they take on the role of coordinating bodies. Institutions are formal or informal norms that frame the interaction between the elements, the actors and their roles and limit the scope of action of these actors. Altogether, they provide a toolbox for the normative design or positive description of concrete organization models.

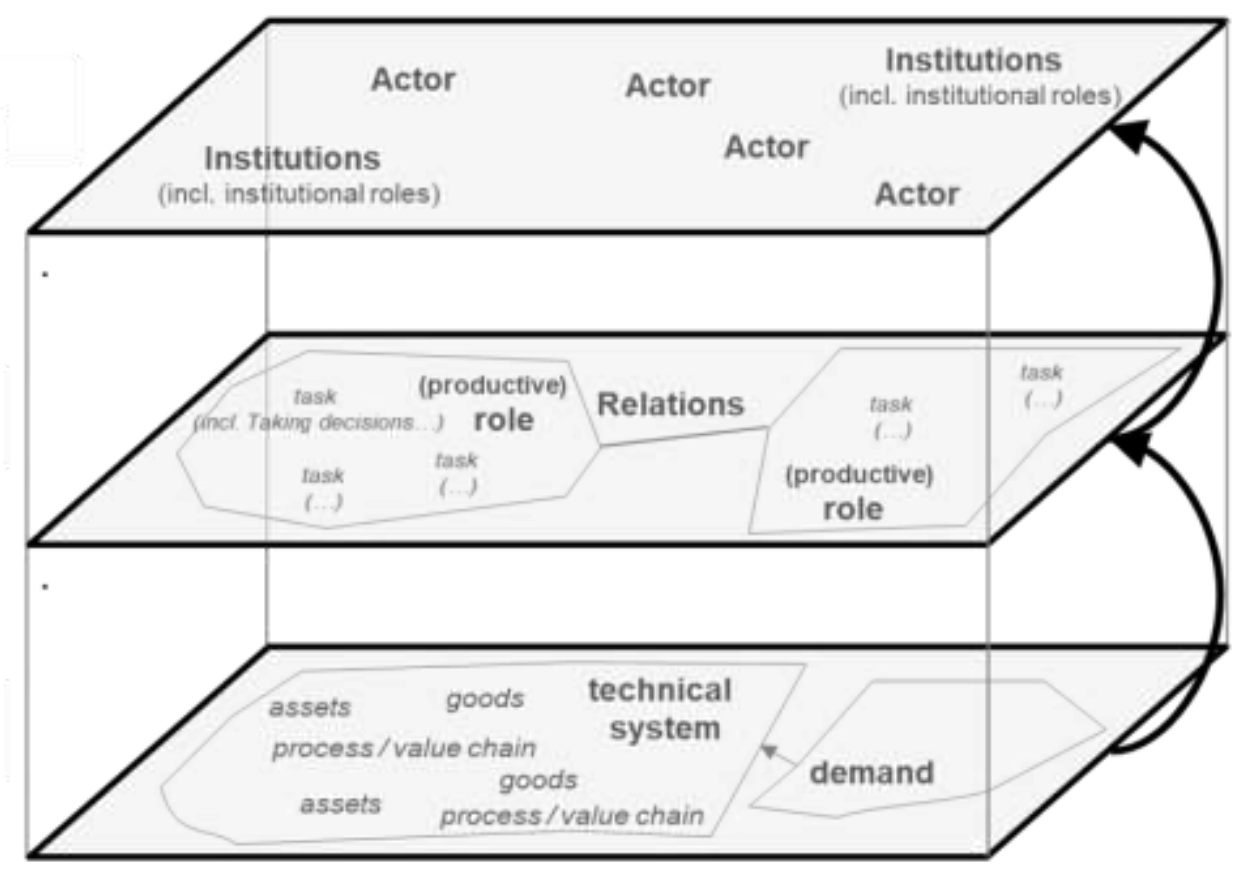

Figure 2: Basic assumptions about key elements.

Source: Gizzi $(2016,10)$. 
For the creation of organizational models, it is recommended to work through the elements of the analysis framework sequentially in the following order, whereby an iterative procedure is also often advisable (Gizzi 2016).

\section{(I) DESCRIPTION OF THE SYSTEM GOOD:}

The starting point for applying the framework is a system good, which must be described with regard to central properties such as technical aspects or quantities.

\section{(II) MAPPING OF THE SySTEM GOOD IN THE ANAL YSIS FRAMEWORK}

1) First, the system good considered should be mapped in the technical system. All relevant (elementary) processes and assets as well as the interdependencies between these technical elements have to be identified.

2) Subsequently, a so-called model of roles can be set up, which forms the basis for the design of organizational models. This contains all roles required for the analysis, as well as the relationships between these roles. Each role should be designed in a way that it is plausible that a single player can perform it. In order not to make the analysis too complex, as few roles as possible should be created.

3) Based on the model of roles, it is possible to identify and structure coordination needs and the associated coordination areas for the defined model of roles.

\section{CREATION Of ORGANIZATIONAL MODELS}

Based on the previous work, various organizational models can finally be created. These include the following elements:

- On the one hand, assumptions have to be made about role performance and thus about which actors are involved in the offer and which role(s) these actors perform in each case. A specific set of such assumptions is called actor model. It makes sense to use one's own terms to describe frequently occurring (ideal-typical) constellations in player models. If, for example, roles linked by spatial-complementary relationships are perceived by different players, these players are referred to as area-complementaries. If in a field one player only perceives a certain role, this player is called a territory monopolist.

- On the other hand, organizational models contain assumptions about the institutions that affect the (decisions of) players.

\subsection{Analysis, economic theories, and judgement values}

In order to analyze the organizational models, economic theories enter the stage. The following established economic theories are compatible with the economic research framework and have already been successfully used in the analysis of organizational models. New Institutional Economics (NIE) to which transaction cost theory is attributed, deal with the analysis of the suitability of alternative institutional mechanisms for the design of coordination areas. In this context, NIE can be used both for the positive analysis of the results of existing organizational models (upon which we will focus) and for the normative analysis of the design of organizational models. Industrial economics deals primarily with the interaction between companies in markets, the effects of strategic behavior of actors in substitutive 
relationships can be estimated. Network economics in particular allow additional statements to be made regarding the interplay of similar interacting elements, which is important, for example, in the presence of network effects.

Theories should enable a value-free and objective determination of parameter values. If, however, an additional comparison (e.g. of different organizational models) is to be made with the aim of establishing a ranking, an additional evaluation, containing a judgement value (i.e., positive or negative assessment), must be carried out. Evaluation criteria must always be traced back to analysis parameters, since the values of the evaluation criteria can only be determined within the framework of an analysis. If more than one evaluation criterion is to be used to create a ranking, a procedure must be defined for determining an overall evaluation from the individual criteria (e.g., by standardization or weighting the criteria).

When the framework is used to design organization models, the analysis parameters should be selected for, which it is expected that the design of the organizational model will have a significant influence on their characteristics; these analysis parameters must be taken into account in the analysis as well as possible interdependencies between them. Beckers et al. (2012) name among other things, the following analysis parameters, that can be used: costs associated with a particular organizational model for offering a system (production and transaction costs); the prices for the system goods as well as for individual services and the associated quantities offered; various distribution indicators can be used as analysis parameters; indicators for the robustness of the offering against disturbances; the flexibility of the offer with regard to adjustments in the event of changes in environmental conditions; in order to take into account the incentives of actors to perform roles, in individual cases it may be expedient to use microeconomic analysis parameters such as expected revenues or something of the kind.

When the framework is used to analyze the implementation of a system good, the analysis should take into account the different phases that an organizational model has to go through (e.g., the utilization phase, the implementation phase) as well as taking into account the interdependencies between these two phases. The analysis parameter transaction costs, for example, can be divided into two analysis parameters on the basis of these phases: On the one hand the ex post transaction costs, which develop with the use of institutions, and on the other hand the ex-ante transaction costs, which result in connection with the mechanism of institutions, can be consulted as analysis parameters. ${ }^{5}$

\subsection{Provisioning - production - financing}

The framework poses that several fields of action need to be considered, analyzed, and combined. Fields of interest are especially the production and financing; and in some cases it is essential to include "provisioning", especially when talking about public goods, common-pool resources, or e.g. in the case of nuclear wastes a "public bad". Ostrom, Schroeder, and Wynne (1993, 73-110), therefore, suggest to differentiate between provisioning and production.

\footnotetext{
5 The ex ante transaction costs include, for example, costs for initiating, drafting, negotiating and concluding a contractual agreement. Examples of ex post transaction costs are costs for the subsequent concretization, amendment or adjustment of an original contract.
} 
$\sim$ The term provision refers to decisions made through collective- choice mechanisms about inter alia, the kinds of goods/services; quantity and quality; how to arrange for the production; how to finance the provision; or how to monitor the performance of those who produce these goods or services (Ostrom, Schroeder, and Wynne 1993, 74).

$\sim$ The term production refers to "the more technical process of transforming inputs into outputs-making a product, or, in many cases, rendering a service" (acir 1987, 7). More generally, one may speak of the "doing" of the process".

$\sim$ As financing is a critical part of provisioning and in some cases, especially for complex goods, provisioning can have high interdependencies with the financing responsibility, therefore Klatt (2011) and Wealer, Seidel, and von Hirschhausen (2019) treat financing issues and responsibilities separately from provisioning and production.

The framework was already applied to different sectors, e.g. the organization of the German motorway system (Klatt 2011) or on the organization of traffic information systems in the digitalization age (Gizzi 2016), or on decommissioning of nuclear power plants and storing radioactive wastes (Seidel and Wealer 2016; Wealer, Seidel, and von Hirschhausen 2019). The presented framework allows to analyze and organizing the mutual dependencies between these categories with production, financing, provision, or hybrid organization models.

\section{The system good nuclear power: A stylized description}

In this section, we translate the system good analysis to the concrete case of the nuclear power industry. Nuclear power is probably one of the most complex system goods imaginable, with a multitude of overlapping and interdependent value-added stages. Our hypothesis is that nuclear power is the "child of scientific research and the military" (Lévêque 2014, 212), the development of which follows an "economies-of-scope"-logic, with a joint production of military and civil products and services (von Hirschhausen 2017). As early as 1947, the Acheson-Lilienthal Report (1946, 10) stated: "the development of nuclear energy for peaceful purposes and the development of nuclear energy for bombs are to a large extent interchangeable and interdependent". The military and civil use of nuclear power are intrinsically linked to one another like Siamese twins (Mez 2012, 62). We follow this approach because "[...] the spread of nuclear power has embodied the illusion that we can split the atom as easily and irrevocably into two roles as we can split it in two - forgetting that nuclear energy is a-tomic and indivisible" (Lovins, Lovins, and Ross 1980, 1144).

However, for the sake of clarity in this paper, we do not describe the system good "nuclear weapon" in detail but rather illuminate the interfaces between the civil and military sectors. Nuclear energy (both military and civil) requires an upstream system of a knowledge base, a physical infrastructure, and a legal and institutional infrastructure; it is a "system good" that cannot be produced without this complex web (von Hirschhausen 2017, 17). Figure 3 shows the technical system of the system good nuclear power, its subsystems (which in themselves are system goods) and the interactions. In Section 4, the individual stages of the value chain are then examined in more detail, while in Section 5 a more in-depth analysis of reactor decommissioning is provided. 


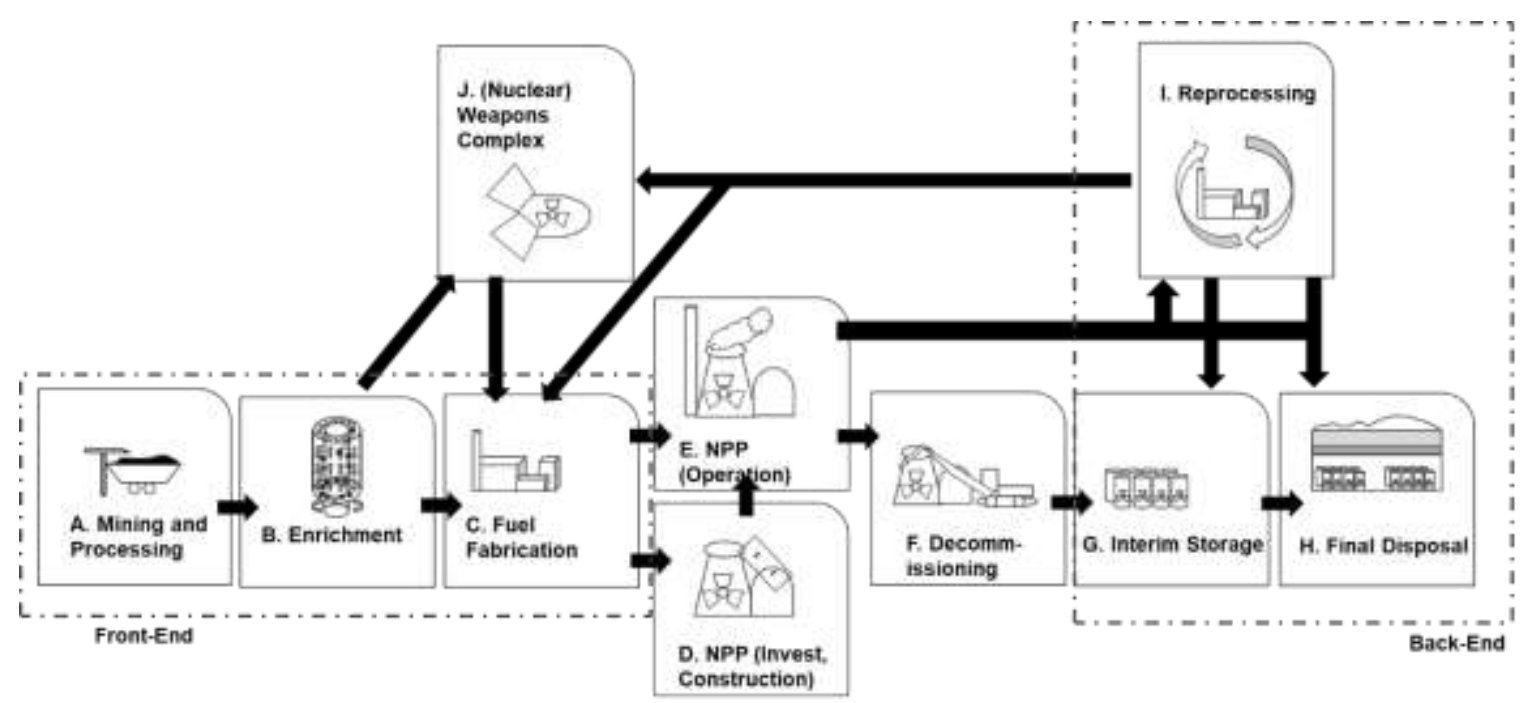

Figure 3: The system good nuclear power.

Source: Own depiction.

\subsection{The front-end: Mining and processing (A), enrichment (B), and fuel fabrication (C)}

In order for uranium ore (or thorium) to be used as a fuel for electricity generation (or for military applications), the natural resource must undergo several processes. The complex value-added chain begins with the mining process - the extraction of the uranium ore (or thorium) from the ground. The mined natural uranium $\left(\mathrm{U}_{238}\right)$ is then grounded and washed and leaves this value-added stage as a socalled "yellow cake". The commercial nuclear power plant fleet consists mainly of light water reactors, which require low enriched uranium (LEU). Today, only a few commercial reactors work with natural uranium (e.g. the Canadian CANDU reactors in operation in Canada, India, and Romania). Light water reactors were not originally part of the technical portfolio in the late 1940s and early 1950s, as enriched uranium was complicated and very expensive to produce. During the Manhattan Project, the United States developed the first large enrichment plant in Oak Ridge, Tennessee. ${ }^{6}$ The enrichment technology is a so-called "dual-use asset", i.e. the technology is in principle applicable to specific civil and military assets. For example, $U_{238}$ is generally enriched with 3 to 5 percent of $U_{235}$ for usage in light water reactors; however, the technology can also be used to enrich uranium to a higher degree and thus produce fissile material that can be used in weapons. A by-product of this enrichment is depleted uranium (DU), which also partially used for military purposes. ${ }^{7}$

\footnotetext{
${ }^{6}$ See Rhodes (2012) for a historical review of the development of the first nuclear weapon.

${ }^{7}$ The military services of the U.S. and Great Britain use depleted uranium in ammunition and projectiles as well as in the armoring of vehicles. One of the main reasons is that this "waste product" is cheap and available in large quantities, and uranium is a very dense and hard metal with a high penetrating power, i.e. armor-piercing. DU ammunition was first used on a large scale in the 1991 Gulf War, in Bosnia and Herzegovina in 1995 and in Kosovo in 1999. For more information also regarding the harmful consequences and risks, see Fairlie (2009), Bleise, Danesi, and Burkart (2003) and Giannardi and Dominici (2003).
} 
Once the uranium has been enriched, the value-added stage "fuel element production" follows, in which the fuel element is produced for subsequent use in the power plant. The production of fuel elements has a high degree of specificity because these high-tech products have to be built according to the individual specifications of the reactor type. This interface represents a coordination area, which is why some fuel element manufacturers are also reactor manufacturers. This value-added stage also has an interface to the nuclear weapons sector. In the USA, for example, plutonium from the weapons arsenal was used to manufacture so-called MOX fuel elements (Hyatt 2017). This overall process (sub-processes A to $C$ in Figure 3 ) is also known as the "front end" of the fuel chain.

\subsection{Nuclear power plant construction (D)}

The next step in the complex value chain is the actual construction of the nuclear power plant. The construction in turn consists of various upstream and simultaneous processes. Particularly noteworthy are the upstream processes of research and development (Cohn 1990), this may relate to the feasibility of the technology or, if the technology is not from the country in question, to the development of an understanding of the design logic. This is followed by the process of designing and manufacturing (or procuring) the nuclear steam supply system, which is performed by the seller, and the design and procurement of the remaining equipment and its integration with the nuclear steam supply system into the overall station design. The actual process of constructing the plant and monitoring it completes the construction process (Thomas 1988, 14sq.).

A historical survey of all nuclear power plant constructions between 1945 and 2017 allows a distinction to be made between four main phases in the development and spread of nuclear power plants (Wealer et al. 2018). The early phase of the use of nuclear power in the post-war period was marked by the looming Cold War between the U.S. and its partner countries on the one hand and the Soviet Union including satellite states on the other. The focus was on the further development of nuclear weapons and other military uses, in particular the production of plutonium. During this period, development was a purely national affair and the countries themselves invented nuclear power and developed technologies, so there was little international cooperation. In the second phase of diffusion, from the 1950s onwards, the geopolitics of the Cold War continued to play a major role and a race between the two nuclear powers began to spread their respective technologies to the states in their own camp. The US approach was much more "liberal", by selling technology and licenses, whereas the USSR kept the technology and only gave away turnkey reactors to satellite states. In parallel, non-aligned states developed their own nuclear programs, such as India, Pakistan and Israel.

In the 1980s and 1990s, the third phase took place with China developed its nuclear sector, to become the third nuclear superpower and the transition from a bipolar to a global, multipolar "second nuclear age" (Bracken 2012). In this phase, at least ten countries came into possession of technology and knowledge about nuclear weapons. In addition to the U.S., the United Kingdom, France and the Soviet Union, China, India, Pakistan, North Korea, Israel and South Africa were or are still in possession of nuclear weapons. The current Post-Fukushima phase is characterized by the implosion of nuclear power in Western Economies, the closure of nuclear power plants due to economic reasons, and abandonment of newbuild projects but also by the rhetoric of the "renaissance of nuclear power" (Sorge et al. 2020). 
However, other countries, especially non-market systems, continue to maintain or enter nuclear power, whether for political, military strategic or other reasons.

Economic history shows that, in the first phase, electricity from nuclear power plants was mainly used as a by-product. ${ }^{8}$ The driving force was military developments and interests, above all the production of weapons-grade plutonium as well the interoperable asset pressurized water reactor, which was only later used for power generation. The current phase is also characterized by an alternative approach: "outsourcing" the entire national innovation system and buying only the "service" of nuclear power and/or nuclear weapons. In the military sector, this may be a strategy of successor states such as Egypt or Sudan, which have been offered the entire chain by Russia or China. ${ }^{9}$ This is also true in the civil sector, where Russia now offers a total package that covers all stages of the value-added chain including a financing package to interested new entrants (Drupady 2019).

\subsection{Nuclear power plant operation (E)}

Once the construction of the power plant is completed, the reactor core loaded and the operating license available, the actual operating phase of the nuclear power plant begins. Originally, the current power plant fleet (second generation) was generally designed for operating years between 30 and 40 years (Jacobson 2019). In the value-added stage "operation of nuclear power plants", the following technical processes are in the foreground: maintenance and repair of technical equipment, loading and unloading of fuel elements, disposal or interim storage of operational waste, and management of spent and highly radioactive fuel elements. The operation has interfaces with other stages of the value chain: fuel elements must be procured, and high-level radioactive waste must be disposed of or temporarily stored or transported to reprocessing. In the following, the interface between operation and decommissioning will also be considered in more detail.

The operational stage of the value-added chain also has interfaces to the military and security sector. For example, nuclear weapon states tend to stick to nuclear power and investing in lifetime extensions (or new power plants), such as the U.S., France and the United Kingdom. Edward Moniz, former US Secretary of Energy under US President Obama (2013-2017), for example, emphasizes that it is essential that policymakers recognize that the civil nuclear sector and the associated supply chains are closely linked and important factors for US national security (Energy Futures Initiative 2017). A recent study by the Atlantic Council estimated the value that the civilian nuclear power sector contributes to the US national security apparatus to around $\$ 42.4$ billion; in other words, the authors argue that the lack of a civilian nuclear sector would present an immediate and significant economic shock (and impact on the labor force) (Ichord and Oosterveld 2019). At present, the UK governments also seem to be committed to nuclear power and one possible reason for continuing to operate nuclear power plants is

\footnotetext{
${ }^{8}$ Nuclear power plants were primarily designed as "plutonium factories with attached electricity production", see Radkau $(1983,53)$ on the development of the first nuclear reactor in the United Kingdom at Calder Hall Nuclear Power Station in 1956.

9 "In order to find original technical solutions, the "second movers" do not need to stand up to a huge R\&D company; they just need clever people and a reasonable, competent group of scientific and technical institutions." See Bracken $(2012,119)$.
} 
to maintain national capabilities to build and operate nuclear powered submarines (Cox, Johnstone, and Stirling 2016).

\subsection{Decommissioning (F)}

Decommissioning has an essential interface to "operation", since the closure of the reactor is a necessary condition for decommissioning the plant. During operations, the licensee of the power plant has to prepare and plan the decommissioning process, which can be characterized by lengthy regulatory processes. The so-called post-operational phase of a nuclear power plant, in which the reactor is unloaded, for example, is often still under the operating license. The operator or the organization responsible for dismantling must also be able to access information, personnel or operating facilities during dismantling. During dismantling, large quantities of low- and intermediate-level radioactive waste as well as high-level radioactive waste are produced which must be disposed of or stored temporarily. The interfaces between "decommissioning" and "interim storage" and final disposal" are considered in the in-depth analysis in Section 5. With only nineteen decommissioned nuclear power plants worldwide and increasing grid decoupling of nuclear power plants, the process of decommissioning is moving more into focus.

\subsection{The back-end: Interim storage (G), final disposal $(H)$, and reprocessing (I)}

Nearly all processes in the different value-added stages generate nuclear wastes. The first wastes that emerge are the tailings (excavated rocks to access the uranium ore) at the uranium mine; all the subsequent processes in the front-end also create nuclear waste. The operation of nuclear power plants produces large quantities of nuclear waste. According to the recent World Nuclear Waste Report, the European commercial nuclear power plants have, for instance, generated around 2.5 million $\mathrm{m}^{3}$ of lowand intermediate-level waste (LILW) (excluding Slovakia, and Russia), of which 20 percent are currently in interim storage. Over 60,000 tons of spent nuclear fuel (excluding Slovakia, and Russia) are in interim storage, of which 81 percent are in wet storage, which comes with its own safety risks. The process of decommissioning may produce another 1.4 million $\mathrm{m}^{3}$ of LILW. Over its (currently estimated) lifetime, the European nuclear reactors may produce around 6.6 million $\mathrm{m}^{3}$ of nuclear waste, which all needs to disposal below ground (Besnard et al. 2019).

The most difficult task is the final disposal of high-level waste (HLW). Concerning what constitutes HLW exactly depends on the national policy and on the nature of the fuel chain. The most widely used strategy for HLW is to store the spent fuel in interim storage facilities, while constructing a deep geological disposal repository for final disposal. Although, more than seven decades after the construction of the first nuclear reactors, still no deep geological repository is in operation (Brunnengräber and Di Nucci 2019).

Another option is the reprocessing of spent nuclear fuel with the idea of extracting uranium and plutonium but only a small part of the reprocessed material will reenter the fuel chain as fresh fuel. Only some of the separated plutonium is reintroduced into the fuel cycle through the fabrication of mixed oxide fuel rods (MOX) while the depleted uranium is in most cases stored and constitutes significant stockpiles. In addition, reprocessing spent nuclear fuel creates large quantities of LILW, meaning that 
the total volume of waste to be managed is much greater than if the spent fuel is treated directly as a waste (Besnard et al. 2019, 23). After reprocessing, the residual fission products and actinides in liquid form are then evaporated and converted to solids by a vitrification process prior to intended further disposal. Reprocessing has also an interface to the military sector and raises proliferation concerns. The plutonium in the spent fuel becomes a proliferation risk if it is extracted by reprocessing (Lovins, Lovins, and Ross 1980, 1140). ${ }^{10}$

\section{Value-added stages and interfaces}

In this section, the value-added stages "nuclear front-end" (A, B, C in Figure 3), "construction of NPPs" (D in Figure 3), and "waste management" (G, H, I in Figure 3) are mapped in the analysis framework. First, the technical system is described in detail; which allows deriving possible tasks, roles, and actors, as well as the relationships between these roles and actors. This allows identifying coordination needs as well as important interfaces. In a third step, organizational models for the production of the good of this value-added stage are described with respect to the involved companies, their governance structure and competition.

\subsection{Nuclear front-end: From mining to fuel fabrication}

\subsubsection{Mapping of the system good "front-end" in the analysis framework}

\subsubsection{Description of the technical system}

In order to use uranium (or thorium) as a fuel for electricity generation (or for military applications), the natural resource uranium ore must undergo several processes. In this section, we describe the necessary processes in order to supply the system good nuclear fuel. These processes are generally attributed to the so-called "front end" of the nuclear fuel chain. Before the end product nuclear fuel can be provided, different production processes need to be carried out, which require in some cases highly specific assets. In addition, some of these processes are interlinked, which leads to the identification of interfaces between corresponding assets. Figure 4 presents this segment of the technical system of the front-end, which is going to described more in detail below.

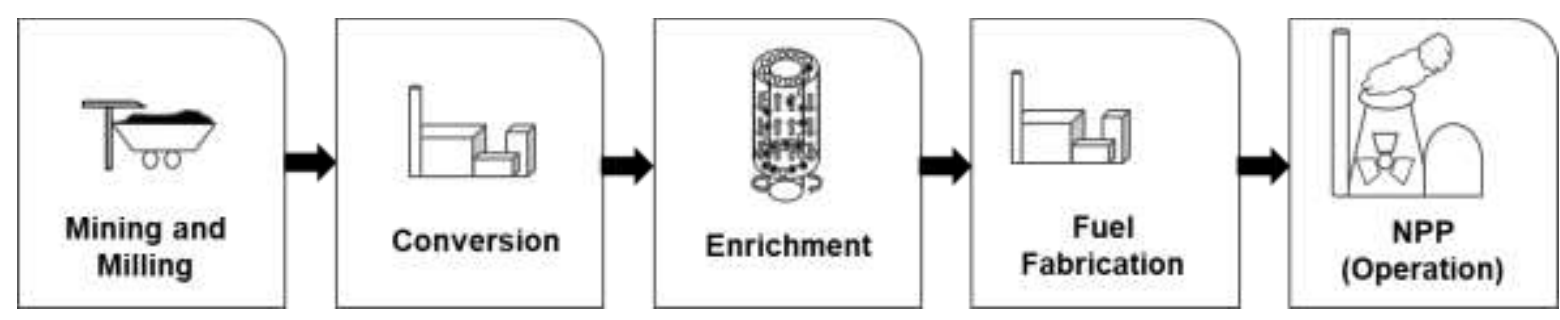

Figure 4: Technical system representation of the "front-end" for light water reactors.

Source: Own depiction.

${ }^{10}$ As explained above, the nuclear weapon complex $(\mathrm{J})$ is not ealth with here. 


\section{MINING AND MILLING}

The first step in the "front-end" is the mining of the uranium ore, so the first asset is the resource uranium itself. In order to explore and mine uranium ore, the uranium ore deposits must first be discovered and classified; a specific technical asset for this is, for instance, air gamma spectrometry tools for resource exploration. Depending on the specific deposit, different mining processes can be used: Open pit and underground mining are the conventional mining processes, while in some cases leaching (in-situ, inplace or heap leaching) is performed. Depending on the exploitation technique, required assets are, e.g., chemicals or pumps for leaching or trucks and conveyors for open pit or underground mining. The most common production method is in-situ leaching (48.1\%), followed by underground mining (31.9\%) (NEA and IAEA 2018, 62).

The next process after mining is the extraction process of $\mathrm{U}_{3} \mathrm{O}_{8}$ of the uranium ore by milling and leaching with acid; the solution is then cleaned, the uranium precipitated and dried. The end product is concentrated triuranium octoxide $\left(\mathrm{U}_{3} \mathrm{O}_{8}\right)$ also called "yellow cake" (Bodansky 2004, 197). ${ }^{11}$ Mining and milling are, both, transformation and transfer processes. Conventional mines have in most cases a mill on their production site, so the transfer is mainly between the intermediary good "yellow cake" and the transport to the conversion service provider. There is a very low degree of substitution for uranium.

\section{CONVERSION AND ENRICHMENT}

The mined uranium consists to $99.28 \%$ of $U_{238}$ and only $0.72 \%$ of $U_{235}$ (relevant for nuclear fission). For normal reactor operation, $\bigcup_{238}$ has to be enriched to about 3-5\% with $\bigcup_{235}$. The majority $(\sim 90 \%)$ of operational commercial power plants are light water reactors and thus use enriched fuel, only a fraction of power plants, e.g. the Canadian CANDU reactors, use natural uranium as a fuel and do not need this step of the nuclear fuel chain. The intermediate process before uranium can be enriched, is the conversion of the $\mathrm{U}_{3} \mathrm{O}_{8}$ cake into uranium hexafluoride $\left(\mathrm{UF}_{6}\right)$, an extremely corrosive gas that converts to hydrofluoric acid when it comes into contact with water, so handling is technically very complex (Neles and Schmidt 2012, 150).

Currently, the most widely used enrichment process is the still diffusion process, which is gradually replaced by the technically superior centrifuge separation process. In the latter, the gaseous $U_{6}$ is fed into a centrifuge and the heavier $\mathrm{U}_{238}$ atoms are separated from the $\mathrm{U}_{235}$ atoms. ${ }^{12}$ This process must be repeated about ten times or more to achieve the desired enrichment level of $U_{235}$ (Neles and Schmidt 2012). What remains is depleted uranium. The technology ${ }^{13}$ used in the uranium enrichment process is highly specific and very sensitive, and therefore always under international control because of the proliferation risks of weapons-grade uranium. Both, conversion and enrichment are transformation processes, while especially the enrichment stage needs a highly specific asset. There is also a transfer process involved, between conversion and enrichment, as well as between enrichment and the next value-added stage, fuel fabrication

\footnotetext{
${ }^{11}$ Mining produces a lot of external effects, like radon exposure of the workers and environmental damages in form of mining residues, the so-called tailings (Bodansky 2004).

12 See Bodansky (2004, 200-201) for more details and a representation of further enrichment technologies.

${ }^{13}$ The performance of a uranium enrichment plant is measured in separative work units (SWU).
} 


\section{FUEL FABRICATION}

The last elementary process consists of the fuel fabrication. In a first step, the enriched $\mathrm{UF}_{6}$ is converted through a chemical process into uranium dioxide $\left(\mathrm{UO}_{2}\right)$, which is then transformed into ceramic $\mathrm{UO}_{2}$ pellets. The last step is the fabrication of the metal framework for the fuel assembly, followed by loading the fuel pellets into the fuel rods, sealing the rods and assembling the rods into the final fuel assembly structure. The resulting fuel elements are high-tech products, which are built according to the individual specifications of each reactor type. ${ }^{14}$ Fuel fabrication is a transformation process, which has interdependencies to the value-added stage "nuclear power plant", more specifically to the nuclear power utility. With fuel elements being high-tech products designed for specific reactors, a strong need for coordination arises between the supplier of fuel elements and the nuclear utilities on the other side. This interface needs to be designed especially in reference to compatibility.

The analysis of the technical system leads to a picture of interdependent processes, which are mostly characterized by a high degree of specifity, a low degree of substitution, and some compatibility. Table 2 gives an overview of the processes and assets needed in the nuclear front-end.

\begin{tabular}{|c|c|c|}
\hline $\begin{array}{l}\text { Elementary } \\
\text { Process }\end{array}$ & Processes & Assets \\
\hline Mining \& Milling & 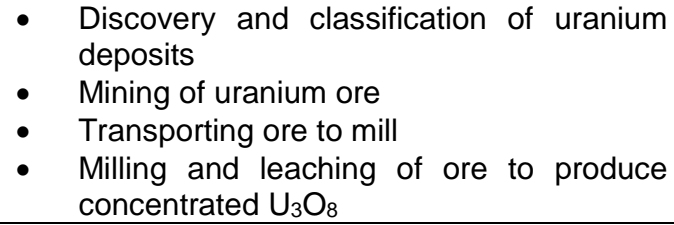 & $\begin{array}{ll}\text { - } & \text { Uranium mines (or ore) } \\
\text { - } & \text { Mining infrastructure } \\
\text { - } & \text { Transport logistic }\end{array}$ \\
\hline Conversion & - $\quad$ Conversion of $\mathrm{U}_{3} \mathrm{O}_{8}$ into $\mathrm{UF}_{6}$ & - $\quad$ Conversion plant \\
\hline Enrichment & - $\quad$ Enrichment of $\mathrm{UF}_{6}$ & $\begin{array}{llll}\text { - } & \begin{array}{l}\text { Enrichment plant } \\
\text { centrifuge) }\end{array} & \text { (e.g., } \\
\end{array}$ \\
\hline Fuel Fabrication & $\begin{array}{ll}\text { - } & \text { Chemical conversion of } \mathrm{UF}_{6} \text { into uranium } \\
\text { dioxide }\left(\mathrm{UO}_{2}\right) \text {, } \\
\text { - } & \text { Transformation into ceramic } \mathrm{UO}_{2} \text { pellets. } \\
\text { - } & \text { Fabrication of the metal framework for the } \\
\text { - } & \text { fuel assembly } \\
\text { Finalizing final fuel assembly }\end{array}$ & $\begin{array}{ll} & \text { Fuel fabrication plant } \\
\text { - } & \text { Decontamination tools) }\end{array}$ \\
\hline
\end{tabular}

Table 2: Processes and assets of the technical system "front-end".

Source: Own depiction.

\subsubsection{Tasks, roles, and actors}

In this step of the analysis, a role model can be set up, in which the major roles required for the analysis, as well as the relationships between these roles are included. We focus here on the role type offer of elementary process, which primarily comprises the combined use of assets to perform elementary processes. All the tasks needed for the elementary processes of "mining and milling", "conversion", "enrichment" as well as "fuel fabrication" could be provided by one specific role respectively. Between each of the roles an ordering relationship would exist, for instance the role "conversion" would order from the role "mining and milling", who would provide concentrated $\mathrm{U}_{3} \mathrm{O}_{8}$. In addition, time-

\footnotetext{
${ }^{14}$ World Nuclear Association. 2020. "Nuclear Fuel and its Fabrication". Accessed April, 14, 2020. https://www.worldnuclear.org/information-library/nuclear-fuel-cycle/conversion-enrichment-and-fabrication/fuel-fabrication.aspx
} 
complementary relationships are traceable between the roles, as the different processes need be carried out in a certain order. Possible areas of coordination are between the enrichment plant and the provision of the conversion service; between the nuclear utility and fuel fabrication, especially towards fuel element structure and reactor specifics.

Actors involved in the nuclear front-end are inter alias the countries in which the uranium deposits are located. The elementary processes of "mining and milling", "conversion", "enrichment", and "fuel fabrication" can be provided by private companies, state companies, or a mixture of both. The second actor is the mining company, which owns the mine and exploits it. Another actor is the provider of conversion services. The specific asset for this process is a commercial conversion plant. Another actor is the provider of enrichment services. The specific asset for this process is an enrichment conversion plant. The last actor in the nuclear front-end, at least from a point of view of production is the provider of the conversion, pelletizing, and final fuel assembly construction services.

\subsubsection{Organizational models for the production of ...}

\subsubsection{1 ... uranium}

Since mid-2011, spending on uranium exploration and mine development is in a steady decline and has again decreased from over $\$ 2$ billion in 2014 by to only $\$ 663,678$ million in 2016 (NEA and IAEA 2018), a reduction by nearly three quarters. In 2017, the "Red Book" of the NEA and IAEA (2018) estimated recoverable uranium deposits ${ }^{15}$ to around 6 million tons, which was apparently equivalent to approximately 130 years of operation of the current global nuclear power plant fleet. Australia has the largest share of identified resources with about one third, followed by Kazakhstan. In total, 95 percent of the identified global resource base is spread across 15 countries, with only three countries (Australia, Kazakhstan, and Canada) controlling more than half of the identified resources. ${ }^{16}$ It is interesting to note that of the three countries, only Canada operates commercial nuclear power plants; while a total of seven (of the 15 countries) also operate nuclear power plants. The major nuclear country France does not operate own French mines, but is exploring "non-local" mines in Canada, Gabon, Kazakhstan, Mongolia, Namibia, and Niger.

The key players in uranium mining are the mining companies that extract the uranium. It should be noted that it typically takes many years for a uranium mining project to move from discovery to production (OECD/NEA 2008, 45). In 2018, nearly 27,000 tons of uranium, or about 50 percent of the world's uranium production, came from only ten mines in five countries. Overall, the most of the uranium was mined in Kazakhstan in 2018 ( $16 \%$ or 8,255 tons). The mine with the largest share of the world production is currently located in Canada. In 2018, about 7,000 tons were mined in the Cigar Lake Mine, which corresponds to 13 percent of the world production. The Cigar Lake in Canada, is operated under a joint venture between Canadian Cameco and French Orano. Several mines are operated under joint

\footnotetext{
15 "Reasonably assured" und "inferred resources"; the former category refers to uranium reserves for which the quantities and concentrations can already be estimated very precisely and reliably; the second category refers to deposits for which less precise information is available (Neles and Schmidt 2012, 147).

${ }^{16}$ Global distribution of the identified resources (as of January 1, 2017): Australia 30\%, Kazakhstan 14\%, Canada $8 \%$, Russia $8 \%$, Namibia 7\%, Brazil 5\%, South Africa 5\%, China 5\%, Niger 5\%, Mongolia 2\%, Uzbekistan $2 \%$, Ukraine $2 \%$, Tanzania $1 \%$, Botswana $1 \%$, United States of America $1 \%$
} 
ventures, wherein in some cases, the mine output is shared between the partners or one of the partners may be responsible for selling all the uranium produced (OECD/NEA 2008, 51). Table 3 provides an overview of the ten largest mines, their production and the main mine owners, ordered by production and Table 4 shows the top four mining companies.

\begin{tabular}{|l|l|c|c|}
\hline \multicolumn{1}{|c|}{ Mine (country) } & \multicolumn{1}{|c|}{ Main Owner } & $\begin{array}{c}\text { Production } \\
\text { [tons] }\end{array}$ & $\begin{array}{c}\text { Share } \\
\text { worldwide }\end{array}$ \\
\hline Cigar Lake (Canada) & Cameco/Orano & 6,924 & $13 \%$ \\
\hline Olympic Dam (Australia) & BHP Billiton & 3,159 & $6 \%$ \\
\hline Husab (Namibia) & Swakop Uranium (CGN) & 3,028 & $6 \%$ \\
\hline Inkai, sites 1-3 (Kazakhstan) & Kazaktomprom/Cameco & 2,643 & $5 \%$ \\
\hline Rössing (Namibia) & Rio Tinto & 2,102 & $4 \%$ \\
\hline Budenovskoye 2 (Kazakhstan) & Uranium One/Kazatomprom & 2,081 & $4 \%$ \\
\hline Tortkuduk (Kazakhstan) & Orano/Kazatomprom & 1,900 & $4 \%$ \\
\hline SOMAIR (Niger) & Orano & 1,783 & $3 \%$ \\
\hline Ranger (Australia) & Rio Tinto/ERA & 1,695 & $3 \%$ \\
\hline Kharasan 2 (Kazakhstan) & Kazatomprom & 1,631 & $3 \%$ \\
\hline Top 10 total & & $\mathbf{2 6 , 9 4 6}$ & $\mathbf{5 1 \%}$ \\
\hline
\end{tabular}

Table 3: The ten biggest uranium mines, as of 2018.

Source: Own depiction based on World Nuclear Association (2019). ${ }^{17}$

\begin{tabular}{|l|l|c|c|}
\hline \multicolumn{1}{|c|}{ Company } & \multicolumn{1}{|c|}{ Main Owner } & $\begin{array}{c}\text { Production } \\
\text { [tons] }\end{array}$ & $\begin{array}{c}\text { Share } \\
\text { worldwide }\end{array}$ \\
\hline Kazatomprom & $\begin{array}{l}\text { The Kazakh National Wealth Fund Samruk- } \\
\text { Kazyna JSC owns 81.28\% of the share capital } \\
\text { of NAC Kazatomprom JSC, 18.72\% is in free } \\
\text { float on the Astana International Exchange and } \\
\text { the London Stock Exchange. }\end{array}$ & 11,074 & $22 \%$ \\
\hline Orano & $\begin{array}{l}\text { The French State directly or indirectly controls } \\
86,52 \% \text { of the capital. }\end{array}$ & 5,809 & $11 \%$ \\
\hline Cameco & Canadian State & 4,613 & $9 \%$ \\
\hline Uranium One & Rosatom & 4,385 & $8 \%$ \\
\hline
\end{tabular}

Table 4: The top four uranium mining companies, as of $2018 .^{19}$

Source: Owen depiction based on World Nuclear Association (2019) ${ }^{20}$, and various sources, compiled by the author.

17 World Nuclear Association. 2019. Accessed June 6, 2020. https://www.world-nuclear.org/informationlibrary/nuclear-fuel-cycle/mining-of-uranium/world-uranium-mining-production.aspx.

18 The shares in Cameco are subject to restrictions on foreign (non-Canadian) ownership (OECD/NEA 2008, 46).

${ }^{19}$ Other mining companies are: CGN Mining Company Ltd from China, BHP, ARMZ (part of Rosatom), Rio Tinto, Navoi Mining from Uzbekistan, Energy Asia (40\% owned by Kazatomprom), CNNC from China, General Atomics/Quasar, VostGok, Sopamin, and others.

${ }^{20}$ World Nuclear Association. 2019. https://www.world-nuclear.org/information-library/nuclear-fuel-cycle/mining-ofuranium/world-uranium-mining-production.aspx. 
The supply side of the uranium market is highly concentrated, with the top four producing mining companies serving about $50 \%$ of the uranium market (Table 4). Kazakhstan continuously increased its production year after year and overtook Canada and Australia in 2009 and has since then been the market leader with a market share of $22 \%$ in 2018 (Vestergaard 2015, 22). ${ }^{21}$ The other three major mining companies Orano, Cameco, and Uranium One have roughly half of the market share (between 8-11\% each). With the acquisition of the Canadian Uranium One company in 2013, Russia, through the Rosatom conglomerate, increased its market share to 13 percent. What these four companies (as well as the majority of the other players) have in common is that they are majority-owned by national states, in this case, the Kazakh, French, Canadian or Russian state. The uranium market is recently changing and new suppliers such as Malawi and emerging suppliers such as Tanzania are entering the market (Vestergaard 2015, 22). One country that is surprisingly missing in this value-added stage of the fuel chain is the U.S. Currently about 93 percent of US uranium is imported, which leads US companies to demand uranium import quotas (Considine 2019).

Vestergaard $(2015,36)$ reports that uranium deals are made under long-term contracts, which are executed several years in advance of the first delivery, and purchased through a bidding process. Only about 20 percent of all uranium was sold on the spot market, and the remaining 80 percent under longterm contracts (Auzans et al. 2014), typically lasting for five years or in some cases ten years or more (Trieu, Savage, and Dwyer 1994). Vestergaard $(2015,36)$ lays out, that buyers tend to diversify their uranium supply as well as the conversion, enrichment, and fuel fabrication services. Power companies are able to tell mining companies how much uranium to deliver to which converter and when to which enrichment service provider. ${ }^{22}$ According to Mendelevitch and Thien Dang (2016), the prices in the longterm contracts can be either fixed or variable during the term of the contract, in the latter the price is based on the spot market price. The demand for uranium is inelastic (Owen 1983), the fact that there is no real substitute for uranium reinforces the singularity of the uranium market (Mendelevitch and Thien Dang 2016). Another aspect of the uranium market that was not treated in this analysis but needs nonetheless mentioning as it effects the uranium market is the interface to the military sector. One of the largest secondary sources of uranium stems from the nuclear weapons programs. For instance, under an intergovernmental agreement (in force between 1993 and 2013) between Russia and the U.S., military high enriched uranium was delivered from Russia to the U.S., which was divided under four companies (then AREVA (30\%), Cameco (30\%), TENEX (30\%), and NUKEM ${ }^{23}$ (10\%) (OECD/NEA $2008,43)$. This is roughly the equivalent of approximately 9,000 tons per year in the form of low enriched uranium, which also had an effect on the demand. ${ }^{24}$

\footnotetext{
${ }^{21}$ In 2018, Kazatomprom acquired $40.5 \%$ of the shares of Energy Asia (4\% market share).

${ }^{22}$ See Vestergaard $(2015,36)$ for a comprehensive analyze of the governance structures of the worldwide uranium market.

${ }^{23}$ Nukem is global nuclear trading company. For reasons of simplification, traders were excluded from this analysis. ${ }^{24}$ For further information on the uranium market, see i.a. Monnet, Gabriel, and Percebois (2017), Rooney, Nuttall, and Kazantzis (2015).
} 


\subsubsection{2 ... for conversion and enrichment}

The only commercial conversion plants in operation, in 2019, are in the U.S., Canada, France, Russia, and China and thus, with the exception of Canada, almost exclusively in nuclear weapons states. Except for ConverDyn, the multinational US company, all conversion plants are in state ownership; although the US conversion plant has stopped its production since 2017 due to a current worldwide oversupply of $\mathrm{UF}_{6}$. The company states, that the decrease in demand from Japan and Germany following the Fukushima accident in 2011 continue to create an oversupplied market for the uranium fuel cycle and a downward trend in uranium markets. ${ }^{25}$

Looking at the actors involved in the conversion services market, the four active companies are also involved in the mining business. The largest conversion plant is operated by Orano in France and by CNNC in China, the latter also has uranium mining in its portfolio. This vertical integration makes sense, as these companies are solely involved in the nuclear sector, while other major mining companies like BHP or Rio Tinto have uranium mining only as a part of their mining portfolio. UF 6 conversion services can be bought on the spot market, but the majority of conversion supply is bought under long-term contracts between the nuclear utilities. ${ }^{26}$ Table 5 provides an overview of the commercial conversion plants, their production capacity, as well as the rate of capacity utilization.

\begin{tabular}{|l|l|c|c|}
\hline \multicolumn{1}{|c|}{ Company } & \multicolumn{1}{|c|}{ Location (Country) } & $\begin{array}{c}\text { Capacity } \\
{[\text { [Tons] }}\end{array}$ & Capacity Utilization \\
\hline Orano & Pierrelatte and Malvesi (France) & 15,000 & $2,500(17 \%)$ \\
\hline CNNC & Lanzhou und Hengyang (China) & 15,000 & $10,000(67 \%)$ \\
\hline Cameco & Port Hope (Canada) & 12,500 & $10,000(80 \%)$ \\
\hline Rosatom & Seversk (Russia) & 12,500 & $12,0000(96 \%)$ \\
\hline ConverDyn & Metropolis (USA) & 7,000 & $0(0 \%)$ \\
\hline Top 10 total & & $\mathbf{6 , 0 0 0}$ & $\mathbf{3 4 . 5 0 0}$ \\
\hline
\end{tabular}

Table 5: Conversion plants and their capacity, as of 2018.

Source: Own depiction based on World Nuclear Association (2020). ${ }^{27}$

Until the 1980s, the "Western" market for enrichment services was monopolized by the U.S. with its diffusion process, while the USSR had the monopoly for the "Eastern" market. However, since the 1980s, companies with gas centrifuge technology, i.e. Russia and the British-Dutch-German company Urenco, have gained increasing market shares (Rothwell 2009). Now, the only operational large-scale

\footnotetext{
25 WNN. 2017. "US conversion plant suspends UF6 production". Accessed June 5, 2020. https://www.worldnuclear-news.org/UF-US-conversion-plant-suspends-UF6-production-2111177.html.

${ }^{26}$ A transaction on the spot market is usually in the form of a purchase of uranium and conversion together (i.e. $\mathrm{UF}_{6}$ ) but priced separately (OECD/NEA 2008, 56).

27 World Nuclear News. 2019. "Conversion and Deconversion ". Accessed June 5, 2020. https://www.worldnuclear.org/information-library/nuclear-fuel-cycle/conversion-enrichment-and-fabrication/conversion-anddeconversion.aspx
} 
commercial enrichment plants are located in the U.S., U.K., France, Russia, and China as well as in Japan, Germany and the Netherlands. Because of the inherent high risk of proliferation, only the nuclear weapon states have enrichment technologies on a commercial scale, with one exception, the Urenco Company. ${ }^{28}$ Urenco is owned one third by the German energy companies PreussenElektra and RWE, one third by the Dutch government and one third by the British government. The company is a specialized company and operates enrichment plants in Germany, the U.K., and the Netherlands. The Russian State owns Tenex, by far the largest enrichment capacity located at four enrichment plants, followed by the French state-controlled Orano. These two companies have also vertically integrated the enrichment services into their portfolio. Japanese JNFL, Chinese CNNC mainly serve the domestic market. Due to the dual-use nature and the complex institutional environment, the majority of supply is conducted under long-term contracts, often with a duration of five or more years (OECD/NEA 2008, 6465). Table 6 gives an overview of the global enrichment companies, their location, as well as their operational and planned capacity.

\begin{tabular}{|l|l|c|c|c|}
\hline Company & \multicolumn{1}{|c|}{ Location } & $\mathbf{2 0 1 3}$ & $\mathbf{2 0 1 5}$ & $\mathbf{2 0 2 0}$ \\
\hline Orano & Georges Besse I \& II (France) & 5,500 & 7,000 & 7,500 \\
\hline Urenco & $\begin{array}{l}\text { Urenco: Gronau (DE); Almelo (NL); } \\
\text { Capenhurst (UK). }\end{array}$ & 14,200 & 14,400 & 14,900 \\
\hline JNFL & Rokkaasho (Japan) & 75 & 75 & 75 \\
\hline Urenco & Urenco (New Mexico) & 3,500 & 4,700 & 4,700 \\
\hline Tenex & $\begin{array}{l}\text { (Angarsk, Novouralsk, Zelenogorsk, } \\
\text { Seversk; Russia) }\end{array}$ & 26,000 & 26,578 & 28,663 \\
\hline CNNC & CNNC (Hanzhun \& Lanzhou; China) & 2,200 & 5,760 & $10,700+$ \\
\hline Others & $\begin{array}{l}\text { Argentina, Brazil, India, Pakistan, } \\
\text { Iran }\end{array}$ & 75 & 100 & 170 \\
\hline & Total separative work units /year & $\mathbf{5 1 , 5 5 0}$ & $\mathbf{5 8 , 6 0 0}$ & $\mathbf{6 6 , 7 0 0}$ \\
\hline
\end{tabular}

Table 6: Global enrichment capacity, operational and planned.

Source: Own depiction based on World Nuclear Association (2019). ${ }^{29}$

\subsubsection{3 ... for fuel fabrication}

Nuclear fuel assemblies are highly engineered products that have to be adapted to the physical characteristics of the reactor. Due to this high specificity, a large part of the fuel fabrication companies are reactor vendors (or owned by them). This holds true for the top three suppliers; Westinghouse and Framatome are major reactor vendors, while the Russian company TVEL, which produces the fuel for the Russian PWRs (VVER), is part of the Rosatom conglomerate. The LWR market can be looked as

28 Urenco is regulated by the $1971 \quad$ Treaty of
https://www.government.nl/documents/publications/2017/06/14/treaty-of-almelo-implementing-act.
29 World Nuclear Association. 2020. "Uranium enrichment". Accessed June 5, 2020. https://www.world-
nuclear.org/information-library/nuclear-fuel-cycle/conversion-enrichment-and-fabrication/uranium-enrichment.aspx 
three single markets (OECD/NEA 2008, 72): a market for boiling water reactors (BWR, dominated by GNF), a market for pressurized water reactor (PWR, dominated by Orano), and the VVER market completely dominated by TVEL, who has a share of almost $100 \%$. However, the market for LWR fuel has become more competitive lately, as several competing suppliers can now supply most fuel types; Russian TVEL is now able to manufacture Western PWR fuel, and Western companies can produce VVER fuel. ${ }^{30}$ In addition, there has been some rationalization in the LWR fuel fabrication industry. The Japanese company Toshiba bought major supplier Westinghouse Electric and purchased Nuclear Fuel Industries (NFI), which it now wholly-owns. In addition, it formed a joint venture with General Electric, and Hitachi a joint venture (Global Nuclear Fuels). Orano (30\%) as well as Mitsubishi Heavy Industries acquired shares of Mitsubishi Nuclear Fuel and created a US fuel fabrication joint venture. Orano and Kazatomprom agreed to build a fuel fabrication plant (a $1200 \mathrm{t} / \mathrm{yr}$ ) in Kazakhstan. Kazatomprom plans to vertically integrate another elementary process of the fuel chain into its portfolio, with it being the current largest uranium producer, it plans to supply a third of the world fuel fabrication market by 2030 , with a possible major customer being China to be an early major customer. ${ }^{31}$

As nuclear fuel assemblies are highly engineered products, the supply of nuclear fuel is generally based on long-term contracts. Changing the nuclear fuel supplier can have costly and regulatory consequences. ${ }^{32}$ Some fuel fabrication companies do not possess the asset "conversion plant", this service has then to be provided by others, while others are even sellers of $\mathrm{UO}_{2}$ powder. Substitute relations between the different players can be expected to emerge as light water reactor fuel can be supplied by several companies. Table 7 informs about the LWR fuel fabrication companies, their respective production capacity in tons per year with respect to conversion, pelletizing, and fuel assemblies as well as production sites.

\footnotetext{
${ }^{30}$ Early in 2016, 41\% of Ukraine's VVER fuel came from Westinghouse in Sweden. In May 2016 Global Nuclear Fuel - Americas agreed with TVEL to produce its TVS-K fuel design in the USA for Westinghouse PWRs. TVEL also plans to market the fuel in Europe, and has been qualifying lead assemblies at Ringhals in Sweden. World Nuclear Association. 2020. "Nuclear Fuel and its Fabrication". Accessed June 5, 2020. https://www.worldnuclear.org/information-library/nuclear-fuel-cycle/conversion-enrichment-and-fabrication/fuel-fabrication.aspx.

$31 \mathrm{https}: / / \mathrm{www}$.world-nuclear.org/information-library/nuclear-fuel-cycle/conversion-enrichment-and-fabrication/fuelfabrication.aspx

32 "In order to change supplier, the NPP must operate for two or three years with a mixed core (i.e. both old and new fuel together), which can be complicated to license and can limit the coverage of fuel warranties from both fuel vendors. The alternative is to reload the whole core with new fuel, which is wasteful and expensive and thus would only be adopted in unusual circumstances. Other complications of changing fuel vendor include: the need to obtain regulatory approvals and make license amendments; differences in the methodologies used for reload safety analyses; and the need to introduce and license new or modified software for reload calculations. For such reasons, switches of fuel supplier are relatively rare, and ten-year contracts with an option for prolongation are not unusual" (OECD/NEA 2008, 73).
} 


\begin{tabular}{|c|c|c|c|c|}
\hline Company & Location & Conversion & Pelletizing & Rod/assembly \\
\hline Westinghouse $\mathrm{AB} / * * /$ & $\begin{array}{l}\text { AB: Västeras (Sweden); }{ }^{* *} \text { : } \\
\text { Springfields (UK); Columbia } \\
\text { (USA) }\end{array}$ & 3,337 & 2,794 & 3,614 \\
\hline $\begin{array}{l}\text { Framatome } \\
\text { FBFC/ANF/Inc. }\end{array}$ & $\begin{array}{l}\text { FBFC: Romans (France); } \\
\text { ANF: Lingen (Germany); Inc: } \\
\text { Richland (USA) }\end{array}$ & 3,800 & 3,250 & 3,250 \\
\hline TVEL MSZ*/NCCP & $\begin{array}{l}\text { MSZ: } \quad \text { Elektrostal (Russia); } \\
\text { NCCP: Novosibirsk (Russia) }\end{array}$ & 1,950 & 2,700 & 2,760 \\
\hline $\begin{array}{l}\text { Global Nuclear } \quad \text { Fuel } \\
\text { Japan/Americas }\end{array}$ & $\begin{array}{ll}\text { Kurihama } & \text { (Japan); } \\
\text { Wilmington (USA) } & \end{array}$ & 1,200 & 1,620 & 1,630 \\
\hline CJNF Jianzhong & Yibin (China) & 800 & 800 & 800 \\
\hline KNFC & Daejeon (Korea) & 700 & 700 & 700 \\
\hline NFI & $\begin{array}{l}\text { PWR: Kumatori (Japan); } \\
\text { BWR: Tokai-Mura (Japan) }\end{array}$ & 0 & 633 & 534 \\
\hline ENUSA & Juzbado (Spain) & 0 & 500 & 500 \\
\hline Mitsubishi Nuclear Fuel & Tokai-Mura (Japan) & 450 & 440 & 440 \\
\hline INB & Resende (Brazil) & 160 & 120 & 400 \\
\hline CBNF & Baotou (China) & 0 & 0 & 400 \\
\hline CNNFC & Baotou (China) & 200 & 200 & 200 \\
\hline DAE Nuclear Fuel Complex & Hyderabad (India) & 48 & 48 & 48 \\
\hline \multirow[t]{2}{*}{ Ulba } & $\begin{array}{ll}\text { Ust } & \text { Kamenogorsk } \\
\text { (Kazakhstan) } & \\
\end{array}$ & 0 & 108 & 0 \\
\hline & & 12,645 & 13,913 & 15,276 \\
\hline
\end{tabular}

Table 7: Global LWR fuel fabrication companies and production capacity, ordered by capacity, in tons per year.

Source: Own depiction based on World Nuclear Association (2020).

\subsection{Construction of nuclear power plants}

\subsubsection{Mapping of the system good "nuclear power plant" in the analysis framework}

\subsubsection{Description of the technical system}

In this section, we look at the central technical characteristics of the system good "nuclear power plant". In general, the technical system "nuclear power plant" can be divided into five subsystems with three input and three output variables (Rothwell 2016). Figure 5 gives an overview of the individual subsystems. Subsystem 1 contains the reactor itself, an apparatus used to maintain nuclear fission in a self-sustaining chain reaction. The reactor is part of the nuclear steam supply system (NSSS) consisting of the reactor core, the reactor coolant system, and auxiliary systems. The nuclear steam supply system produces steam or another hot gas and can include other different technical components depending on the reactor technology (e.g., heat exchanger and pressurizer in a pressurized water reactor). The steam is transported to the turbine building (subsystem 3), where the steam is expanded in the turbine and converted into electrical energy in the generator. The expanded wet steam is transported to the 
condenser (subsystem 5) where it is cooled and the water is transported back to the steam supply system, thus completing the water cycle. The balance of plant includes the other systems, i.e. components that are not included in the nuclear steam supply system (e.g. measurement and control systems, electrical engineering). The transformer (subsystem 4) transmits the electrical power to the transmission grid connection at the busbar.

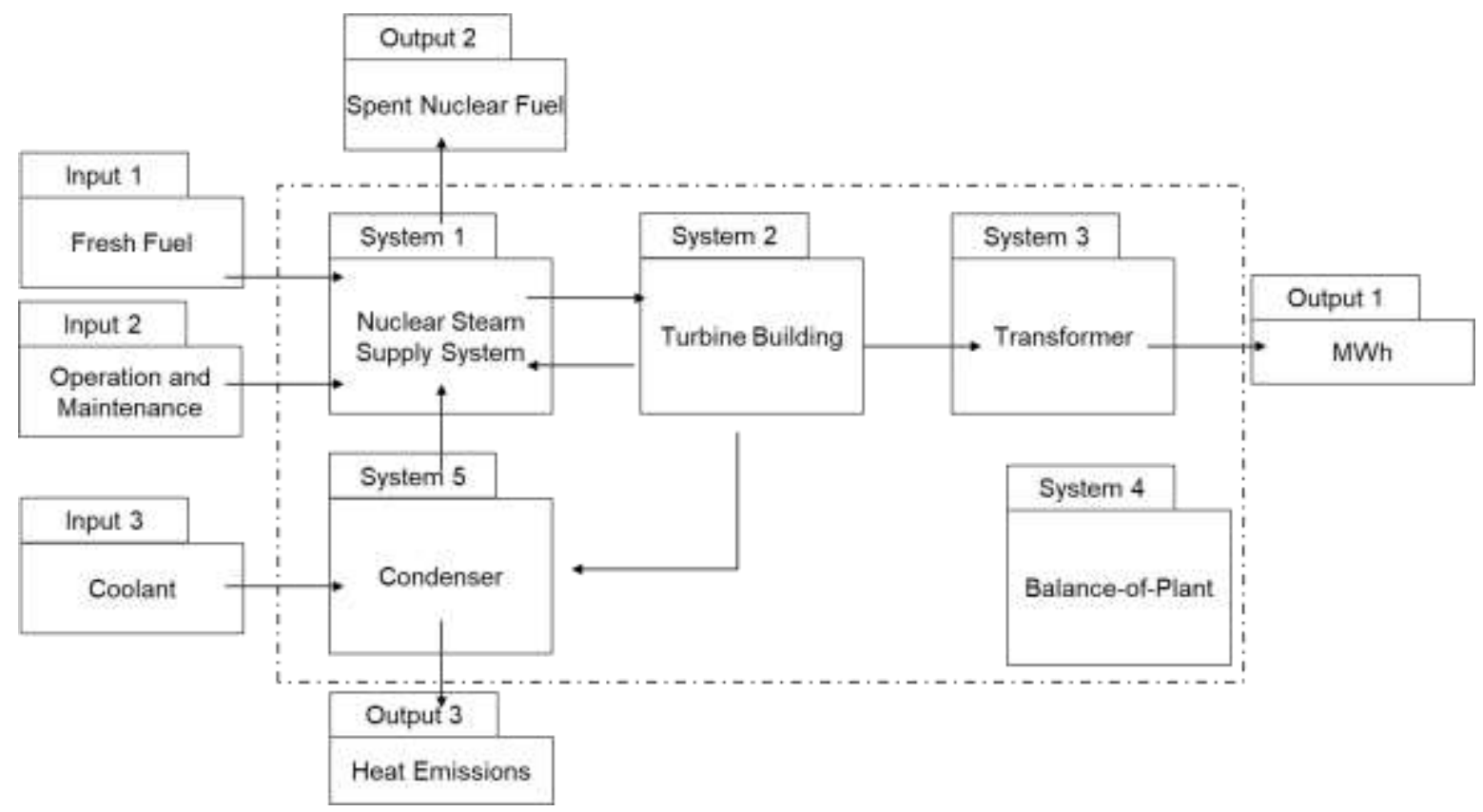

Figure 5: System diagram of a nuclear power plant.

Source: Own depiction based on Rothwell $(2016,3)$ und NRC 10 CFR §170.3.

This division into five subsystems with in- and output variables is also helpful for identifying the needed elementary processes and assets for providing a nuclear power plant. In this analysis we distinguish between the nuclear steam supply system (or nuclear island) and the rest of the plant. The construction of a nuclear power plant consists of several processes, not all of which can be listed here. Thomas (1988, 14-15) distinguishes the following elementary processes from the construction of a nuclear power plant from a conventional power plant: Research and development in the field of technology to determine its viability or to develop an understanding of the logic of the design if the technology does not originate in the respective country; design and manufacture (or procurement) of the nuclear steam supply system; design and procurement of the remaining equipment and its integration with the NSSS into the overall station design; the construction of the plant.

In this analysis, we leave aside the necessary processes for constructing the turbine building, transformer, balance-of-plant, and condenser, for which we assume a more or less competitive market exists, as they are also needed for conventional power plants. Instead, we focus on the provision of the nuclear island and the needed construction and engineering services in order to construct the overall station, which can normally only be supplied by specialist nuclear vendors. Therefore, it makes sense, 
from a production point of view, to distinguish the "nuclear island" from the rest of the power plant. ${ }^{33}$ The nuclear steam supply system is often manufactured specifically for a particular reactor design. Parts of this system are the most critical components, as they require heavy forgings. For example, the containment vessel, reactor pressure vessel, and steam generators of a third generation nuclear power plant are made from nearly 200 forgings comprising over 4,000 tons of steel, with some ingots weighing 500-600 tons each (WNA 2016). There are only a limited number of forging presses in the world able to handle such large blocks.

The analysis suggests several interdependent processes, which can be of a high degree of specificity, especially the construction of the nuclear island. The construction of a nuclear power plant consists mainly of a high number of transformation and transfer processes, some of which are interlinked. From a project management view, the supply and construction of the nuclear island is with a high degree of certainty on the critical path of the project as the "heart of the power station" and thus interlinked to all other construction processes. All of these processes are complementary to the overall well functioning of the power plant. Especially, the process of construction the nuclear island is highly specific. Figure 5 helps to identify some other interfaces: Another important technical interface (Input 1), as described in Section 4.1.1.1, exists to the fuel fabrication company with fuel elements being high-tech products designed for specific reactors. Another important interface is towards the value-added stage "storage" or "disposal", as spent nuclear fuel (output 2) needs to be evacuated from the reactor and consequently stored.

\subsubsection{Tasks, roles, and actors}

Between the different roles that need to be fulfilled for constructing a nuclear power plant, various relationships exist. There are ordering relationships, for instance between the constructor and the reactor vendor or between the reactor vendor and a forging company. During such a construction project, various time-complementary relationships exist and need to be managed, e.g., between the forging company for reactor pressure vessels and the reactor vendor. We focus here on the role type offer of elementary process, which primarily comprises the combined use of assets to perform elementary processes. Of focus are the elementary processes provision of "the nuclear seam supply system" and the provision of the "reactor pressure vessel". While in some cases both processes can be fulfilled by one role, for instance by the reactor vendor, in some cases the vendor has to subcontract this task to a specialized forging company. Of course, a time-complementary relationship exists between these two roles. In the following, the emphasis will be on the two roles of rector vendor, and forging company.

The design and manufacturing (or procurement) of the nuclear steam supply system is usually provided by reactor vendors. The design and procurement of the remaining equipment and its integration with the NSSS into the overall station design can be carried out for instance by the role of architect-engineer, as it is the case in the U.S (Thomas 1988). The process of supervising the construction is carried out by the constructor role.

\footnotetext{
${ }^{33}$ It also makes sense from a cost perspective, because the reactor equipment alone can account for between 20 (University of Chicago 2004) and 40\% (Rothwell 2016) of direct costs.
} 
Of course, different institutional settings influence the roles in a NPP construction project. OECD/NEA $(2008,25-26)$ provides an overview of the three main contracting approaches for constructing nuclear power plants: turnkey approach, split-package, and multi-contract approach. In the turnkey approach, one large contract between the reactor vendor (or consortium) and the customer covering the supply of the entire plant is drawn up. This includes everything from the design and licensing work to the moment, where the vendor hands over the "key of a working plant" over to the costumer (e.g., supply of all equipment and components, all on-site and off-site fabrication, assembly and construction work, testing and commissioning). The vendor can sub-contract work, which he is not able to supply herself. The customer can also opt for the split-package approach, here the project is divided into a few major systems, each contracted to a different supplier, like for instance the systems described in Figure 5. ${ }^{34}$ The multi-contract approach gives the customer the maximum control over the design and construction of the plant, but on the other hand, she has in this approach also the most responsibility for the overall project. As only a few large nuclear utilities have the necessary resource (i.e. nuclear in-house expertise) to carry out this role, an architect-engineer will usually be contracted as the overall project manager. The architect-engineer is responsible for i.e. the overall design, licensing, contractor selection for each of the plant's systems, for managing the actual construction work, and finally, for plant testing and commissioning (OECD/NEA 2008, 25-26).

We focus our analysis on two key actors necessary for the production, which can be private companies, state companies, or a mixture of both: First, the reactor vendor, who provides the "reactor island construction" and the actor who provides the necessary forging capacities, which requires a highly specific investment into large-scale forging capacities. Other possible actors, which are not part of this analysis but need nonetheless mentioning, are the regulator who authorizes and supervises the construction, the financier who provides the capital for the investment, and the state or government. Especially, the roles of financier and the state play an important part in constructing nuclear power plants, as not only can the state be either the financier, or incentivize the construction through various form (e.g. production tax credits, loan guarantees).

\subsubsection{Organizational models for the production of nuclear power plants}

The nuclear industry as a child of science and warfare (Lévêque 2014, 212) has never been an object of private, competitively organized investment, but is subject to collective planning decisions. The early phase of the commercial use of nuclear power in the post-war period (1945 to the 1950s) was marked by the looming Cold War between the USA and its partner countries on the one hand and the Soviet Union including satellite states on the other. ${ }^{35}$ The focus was on the further development of nuclear weapons and other military uses and was, of course, firmly in state hands. The first private companies entered the nascent reactor market at the end of the 1950s and beginning of the 1960s.

\footnotetext{
${ }^{34}$ In a split-package approach it is necessary to allocate responsibility for design and licensing for the overall power plant, an important elementary process is the "integration of the various packages to ensure that the power plant's systems work together correctly". This role can be filled by e.g. by the plant's owner.

${ }^{35}$ See Wealer et al. (2018) for a world-wide historical analysis of the diffusion of 647 built reactors
} 
The first and second-generation reactors were mainly built by companies such as Westinghouse Electric Co. in the U.S., Kraftwerk Union (KWU) in West Germany, or Toshiba Corp. in Japan. This first expansion was also marked by the fact that these companies mainly served the domestic market - they were indigenous or "home suppliers" (Thomas 2010). The large number of companies involved in the early days of nuclear power was first reduced through industrial restructuring in the 1970s, as the nuclear construction market was not large enough; while the decline in construction in the 1980s encouraged further industry consolidation, leaving today only a handful of consolidated nuclear reactor vendors (WNA 2016, 70-71). Among them are, the traditional reactor vendors Westinghouse and Framatome, which are currently in financial turmoil and struggling to survive. ${ }^{36}$ Since the turn of the century, Russia became the emerging nuclear vendor (Thomas 2018; Drupady 2019; Nakano 2020; Sorge et al. 2020) and dominates the reactor market with more technology agreements than the four next largest suppliers (France, USA, China, Korea) combined (Jewell, Vetier, and Garcia-Cabrera 2019). Other players are the state-owned companies from China (CGN, CNNC) (Thomas 2017, 2019) and Korea (KEPCO).

The majority of the current new-build projects is situated in Asia and in the former USSR and is still done by home suppliers, e.g. in China by majority-owned Chinese companies, in Korea by the state-owned monopolist KEPCO, or in Russia by state-owned Rosatom. Since the 1980s, there has been a trend of transferring the reactor license, e.g., the French PWR fleet is based on a Westinghouse license, and the Chinese fleet is partially based on the technology transfer from the "West", e.g. the AP-1000 and the EPR license was also transferred to China. Table 8 shows the reactor vendors and the number of their construction projects.

\begin{tabular}{|l|c|c|c|}
\hline \multicolumn{1}{|c|}{ Reactor Vendor } & $\begin{array}{c}\text { Number of } \\
\text { construction projects }\end{array}$ & Share [\%] & HHI \\
\hline Rosatom (incl. Atomstroyexport) & 17 & 31,48 & 991 \\
\hline CGN & 8 & 14,81 & 219 \\
\hline KEPCO & 9 & 16,67 & 278 \\
\hline Westinghouse & 6 & 11,11 & 123 \\
\hline Framatome & 4 & 7,41 & 55 \\
\hline Nuclear Power Corp. Of India & 4 & 7,41 & 55 \\
\hline CNNC & 2 & 3,70 & 14 \\
\hline CNNC-CGN & 2 & 3,70 & 14 \\
\hline GE-Hitachi & 2 & 3,70 & 14 \\
\hline \multicolumn{1}{|c|}{ Total } & $\mathbf{5 4}$ & $\mathbf{1 0 0}$ & $\mathbf{1 , 7 6 3}$ \\
\hline
\end{tabular}

Table 8: Calculation of the HHI for construction projects by reactor vendor, as of late 2017.

Source: Own depiction based on Wealer et al. (2018) and World Nuclear Association (2016).

\footnotetext{
${ }^{36}$ Westinghouse went into bankruptcy in 2017, and Framatome (then Areva) was bailed out by the French State with 4-5 billion Euros.
} 
The World Nuclear Association counts 11 reactor vendors and considers the reactor market, despite its high degree of consolidation, to be a competitive marketplace with moderate concentration. A calculation of the market concentration of 154 NPP planned construction projects (in 2017) sees Rosatom (including AtomStroyExport) as the main reactor supplier with 41 units. The Herfindahl-Hirschman Overall Index $(\mathrm{HHI})$ is 1,358 , i.e. the market is still below the threshold of over-concentration $(\mathrm{HHI}$ equal to or greater than 1,500); followed by CGN with 25, KEPCO with 16 and Westinghouse with 14 projects (see Table 4.2 in the World Nuclear Association 2016 for more details). However, of these 154 projects, only 54 were actually underway at the end of 2017 , while the majority of projects existed only on paper and will probably never be implemented.

Therefore, we have updated this analysis with the actual construction projects worldwide (in 2017). Table 8 shows that Rosatom still strongly dominates the reactor market with a market share of about 32 percent and that the market is indeed over-concentrated with a HHI of more than $1,500(1,763)$. Table 9 shows the same exercise but this time the vendors a clustered by the supplier country, which raises the over-concentration even more. The top three reactor vendor countries are Russia, China, and Korea, which share over 70 percent of the world market. The U.S. and Japan are the only two countries where "privately-owned" companies construct reactors. The three top installers are in fact state-owned companies with a more "centralized planning" and less market oriented economic system with a close utility-regulatory agency connection. The close connection and cooperation between the reactor vendor and the state facilitates the export of reactors too, especially through Export Credit Agencies. In addition, Russia and China provide a strong government backed package including financing as a policy tool (Thomas 2019).

\begin{tabular}{|l|c|c|c|}
\hline \multicolumn{1}{|c|}{ Country } & $\begin{array}{c}\text { Number of NPP } \\
\text { construction projects }\end{array}$ & $\begin{array}{c}\text { Share } \\
{[\%]}\end{array}$ & HHI \\
\hline Russia & 17 & 31,48 & 991 \\
\hline China & 12 & 22,22 & 494 \\
\hline Korea & 9 & 16,67 & 278 \\
\hline USA & 6 & 11,11 & 123 \\
\hline India & 4 & 7,41 & 55 \\
\hline France & 4 & 7,41 & 55 \\
\hline Japan & 2 & 3,70 & 14 \\
\hline \multicolumn{1}{|c|}{ Total } & $\mathbf{5 4}$ & $\mathbf{1 0 0 , 0 0}$ & $\mathbf{2 . 0 1 0}$ \\
\hline
\end{tabular}

Table 9: Calculation of the HHI for construction projects in late 2017 , by supplier country.

For the construction of nuclear power plants, the degree of integration is of interest, especially the degree of horizontal integration (Coase 1937; Williamson 1985). This gives a reactor vendor more control over production capacity and prices, i.e. a higher degree of self-sufficiency, as he would be able to supply a high proportion of the needed components for reactor construction from its own factories (Thomas 1988). A classic horizontally integrated supplier is for example Framatome (former Areva), 
which owns the forge site Le Creusot, where e.g. reactor pressure vessels are produced. Westinghouse, on the other hand, had already in the 1960s the two reactor pressure vessels for the Prairie station in Minnesota forged by Le Creusot (WNA 2016, 76). Today, production of large components will generally be subcontracted to specialist companies and built on a one-off basis, presumably at higher costs in countries such as Japan and China (Thomas 2010, 19-20). A concept similar to horizontal integration but from a national and not a corporate point of view is the degree of localization, i.e. the existence of a self-reliant domestic nuclear supply chain. A high degree of localization can be observed in France, Japan, Korea, China, and Russia, while the U.K. and the U.S. have more or less abandoned localization and are dependent on imports for a large number of components, especially the reactor pressure vessel. The degree of localization can also influence the production costs and give the company a competitive edge..$^{37}$

The most critical components of a nuclear power plant are the ones attributed to the nuclear steam supply system, as they require heavy forgings. The containment vessel, the reactor pressure vessel, and steam generators of a third generation nuclear power plant are made from nearly 200 forgings, amounting to over 4,000 tons of steel, with some ingots weighing 500-600t tons each. Worldwide, only a limited amount of forging presses exist that can except such large ingots. The WNA estimates the annual worldwide production capacity of RPVs to be sufficient for 30 large reactors (WNA 2016, 98). Table 10 shows the very large forging companies in operation (in 2016), their heavy forging presses capacity, and the number of RPVs (or other large components) they can produce in one year (no data given on Le Creusot).

\begin{tabular}{|l|c|c|c|}
\hline \multicolumn{1}{|c|}{ Company } & Country & $\begin{array}{c}\text { Heavy Forging Presses } \\
{[\text { Tons] }}\end{array}$ & $\begin{array}{c}\text { Reactor Pressure } \\
\text { Vessels Per Year }\end{array}$ \\
\hline Japan Steel Works & Japan & $14,000 \times 2$ & 12 \\
\hline China First Heavy Industry & China & 15,000 and 12,500 & 5 \\
\hline China Erzhong \& Dongfang & China & $16,000 \& 12,700$ & 5 \\
\hline Shanghai Electric Group & China & 16,500 and 12,000 & 6 \\
\hline OMZ Izhora & Russia & 15,000 & 4 \\
\hline Le Creusot, Areva & France & 11,300 and 9,000 & - \\
\hline
\end{tabular}

Table 10: Forging companies for reactor pressure vessel production and their production capacity.

Source: World Nuclear Association (2016).

Apparently, the main very heavy forging capacities are located in Asia, the main actor being Japan Steel Works (JSW), which accounts for 80 percent of the world market for large forged components for NPPs

\footnotetext{
${ }^{37}$ Localization can also be a part of a deal: In 2016, Russia and Egypt concluded a financial deal for four VVER1200 units. The deal foresees also a localization level of around $20 \%$ for the first unit, to be increased for the remaining units.

${ }^{38}$ Or other major component.
} 
and is also contracted to supply Framatome. In 2009, Westinghouse was already constrained as the RPV covers and steam generator parts for the AP1000 could only be supplied by JSW. Another leading reactor pressure vessel supplier is Mitsubishi Heavy Industries (MHI), which together with JSW supplied the reactor pressure vessel to Olkiluoto-3. Other companies are China First Heavy Industry in China, OMZ Izhora in Russia and Le Creusot in France (World Nuclear Association 2016, 96-105). Le Creusot in France, which has been part of the Framatome Group since 2006, has recently been in hot water and is currently under investigation for irregularities in quality control documentation and manufacturing defects in the forgings produced for the EPR for Flamanville-2 and in the reactors in operation, which led to several shutdowns in 2016. The RPV for the Chinese EPR Taishan-1 was supplied by MHI, while the RPV of Taishan-2 was manufactured by Dongfang Electric Corporation; however, the vessel bottoms and lids are not specifically mentioned (Schneider et al. 2017, 48). The supply chain for components for the nuclear island seems to be prone to constraints.

With regard to the decision to provide nuclear power plants, there is consensus on a centrally planned, state decision, since decentralized, private actors have no economic interest in such a plant (Davis 2012; Joskow and Parsons 2012; D'haeseleer 2013; Wealer, Bauer, Göke, Christian von Hirschhausen, et al. 2019). Production can then be carried out by the state (integrated) or by awarding contracts to private actors in connection with regulatory agreements. Traditionally, governments can use public sector funds (especially for the introduction of nuclear ${ }^{39}$ ) or have equity interests (Barkatullah and Ahmad 2017). Examples of this are the state-owned companies Framatome and EDF in France, KEPCO in Korea, or equity interests in joint venture agreements, e.g. the joint venture between China General Nuclear (CGN) and Electricite de France (EDF) for the construction of the Taishan EPR in China or EDF/CGN for Hinkley Point $C$ in the United Kingdom. Other forms of government financing mechanisms include additional cost recovery rates or surcharges on electricity sales (e.g., Vogtle project in Georgia, USA), the use of national funds, the creation of a government-led private bank, banks to finance infrastructure and asset pooling. Support and incentives for nuclear projects can also be provided by governments in the form of loan guarantees (e.g. Vogtle project), guaranteed long-term electricity contract agreements (e.g. Hinkley Point C) or with export credit agencies (e.g. the France Coface loan to the Finnish energy utility TVO for Olkiluto-3 in Finland) (Wealer, Bauer, Göke, Hirschhausen, et al. 2019).

In general, the complex nature of a nuclear power plant requires a considerable degree of "after sales" service from the vendor (OECD/NEA 2008, 31). In most cases, the vendor also supplies fuel services, as the majority of the major vendors (e.g. Westinghouse, Rosatom, Framatome) have vertically integrated fuel companies into their firm structure. Most reactor vendors also provide maintenance and replacement services during the reactor's lifetime.

\footnotetext{
39 Pittman $(1961,1566)$ reports annual expenditures of around 200.000.000 USD for the US civil reactor program, e.g. the Power Reactor Demonstration Program in the U.S.
} 


\subsection{Nuclear waste management}

\subsubsection{Mapping of the system good "waste management" in the analysis framework}

\subsubsection{Description of the technical system}

Nearly all processes in the different value-added stages generate nuclear wastes. ${ }^{40}$ The first kind of waste that emerges is the tailings (excavated rocks to access the uranium ore) at the uranium mine; all the subsequent processes in the front-end create nuclear waste. Figure 6 gives an overview of the nuclear fuel chain and the different generated waste forms along this chain. We focus in this section on operational (dark blue in Figure 6), decommissioning (purple Figure 6), and high-level wastes in the form of spent nuclear fuel (SNF) and vitrified waste from reprocessing (both brown in Figure 6).

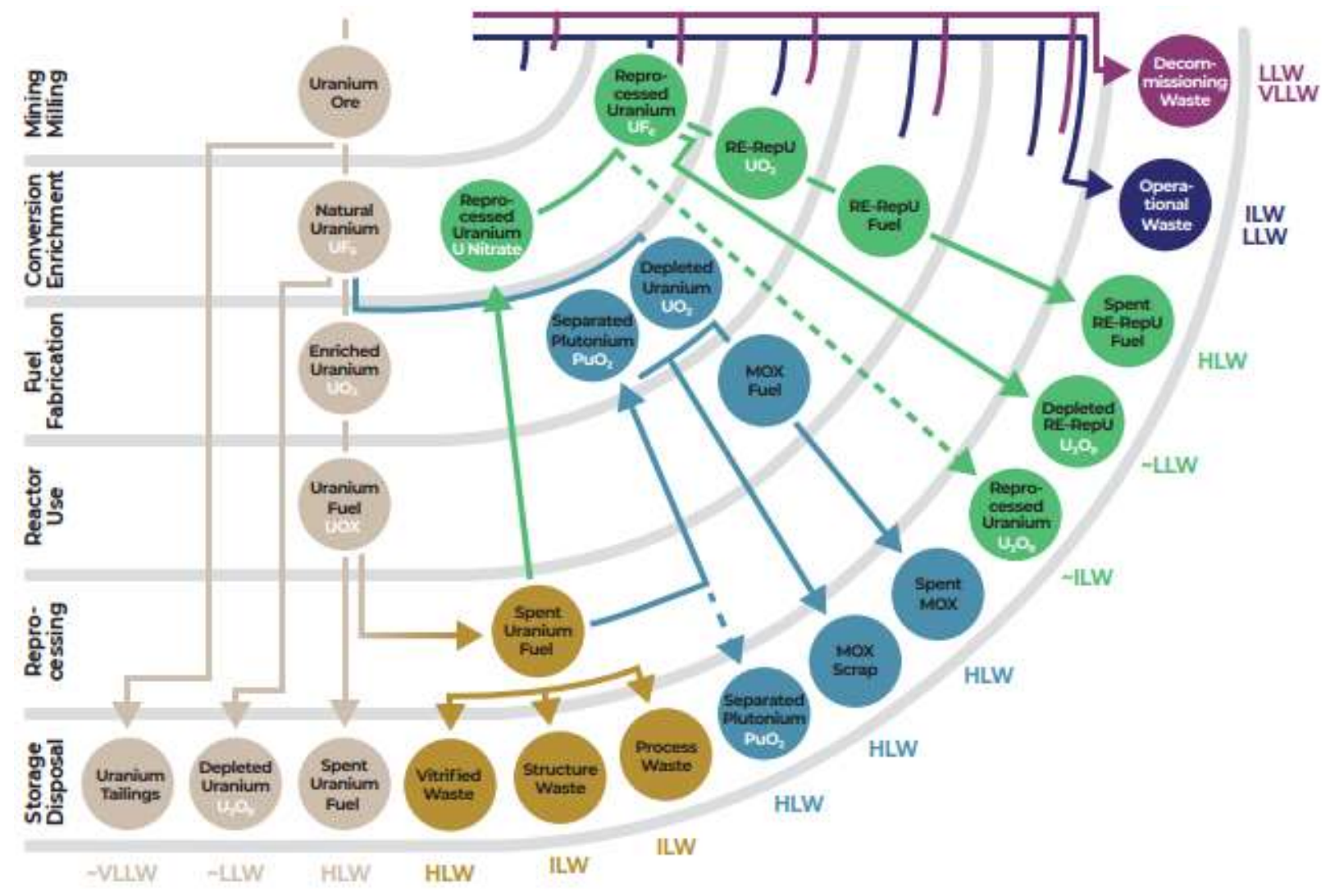

Figure 6: The nuclear fuel chain and generated wastes.

Source: WISE-Paris in Besnard et al. (2019).

\section{WASTE CLASSIFICATION AND MANAGEMENT APPROACHES}

The IAEA (2009) safety guide classifies nuclear waste according to its activity concentration into: Exempt waste, very short-lived waste (VSLW), very low-level waste (VLLW,) low-level waste (LLW,)

\footnotetext{
40 This section is largely based on own publications; i.a. Chapter "Quantities of Nuclear Waste" published in the World Nuclear Waste Report (Besnard et al. 2019), and Wealer, Seidel, and Hirschhausen (2019).
} 
intermediate-level waste, and high-level waste (HWL). ${ }^{41}$ We focus in this section on LLW, ILW, and HLW as these wastes require the most sophisticated waste management infrastructure. LLW is above clearance levels, but with limited amounts of long-lived radionuclides that require robust isolation and containment for periods of up to a few hundred years. ILW consists particularly of long-lived radionuclides, in particular alpha-emitting radionuclides - and requires a greater degree of containment. ILW needs no - or limited - provision for heat dissipation during its storage and disposal. Because ILW consists mainly of long-lived radionuclides that will not decay to a level of activity concentration acceptable for near surface disposal, ILW requires disposal at greater depths, of the order of tens of meters to a few hundred meters. High-level Waste (HLW) has levels of activity concentration high enough to generate significant quantities of heat by the radioactive decay process or waste with large amounts of long-lived radionuclides that need to be considered in the design of a disposal facility.

For each of these waste classes, the IAEA (2009) recommends a possible disposal route. VLLW can be disposed in a specific landfill disposal site, similar to conventional landfills. LLW is most suited to be disposed of in near-surface disposal facilities; these are engineered trenches or vaults on the ground or tens of meters belowground level. ILW is to be disposed of "deeper in the ground" in belowground facilities, which consists of constructed caverns or vaults, or the building of mines in tens of meter up to hundreds of meters belowground. HLW is supposed to be disposed of in geological disposal facilities; this means siting of a facility deep underground in a stable geological setting (e.g. clay, salt, granite). In addition, the waste is supposed to be surrounded with engineered barriers that protect the waste and limit the movement of radionuclides if they were released from the waste packages (IAEA 2009).

\section{OPERATIONAL AND DECOMMISSIONING WASTE}

The operation of a nuclear power plant produces different types of nuclear waste in different physical states, the lion's share of which is LILW. The generation rate of operational waste depends on many factors, such as the deployed reactor technology and the age of the reactor. The IAEA gives an overview of LILW generation of unconditioned LILW per 1-Gigawatt (GW) of capacity by nuclear reactor technology; a light water reactor produces between 250-600 $\mathrm{m}^{3}$ (IAEA 2007b). For unconditioned operational waste, it is important to indicate the state of aggregation, e.g. liquid or solid. Solid waste is for example protective clothing, replaced plant components, or insulation material. Liquid waste is for example cooling water contamination, oils, vaporizer concentrates, filter substances, or sludge, which forms when solid matter collects as sediment at the bottom of pumps (IAEA 2007a). There are various transformation processes in waste management (e.g., pre-treatment, compactation, incineration). We focus here on the main elementary processes; among them is the transformation process conditioning; where waste is brought into a stable and immobilized form, which makes it suitable for transportation,

\footnotetext{
${ }^{41}$ Exempt waste is waste that meets the criteria for clearance, exemption or exclusion from regulatory control. Very short-lived Waste (VSLW) has radionuclides with very short half-lives; VSLW can be stored up to a few years to profit from the radiological decay. After this period, it can either be cleared from regulatory control for uncontrolled disposal, use or discharge, depending on the arrangements with the regulatory body. VSLW consists primarily often used for research and medical purposes. Very low-level Waste (VLLW) does not need a high level of containment and isolation and is suitable for disposal in near surface landfill type facilities - that may contain other hazardous wastes - with limited regulatory control. Typical VLLW is for example soil and rubble with low levels of activity concentration; concentrations of longer-lived radionuclides are generally very limited.
} 
storage, and eventually disposal. ${ }^{42}$ After conditioning, the waste is either stored in drums, storage, transport, or disposal casks (storage process), for which a necessary asset is either an interim storage facility; or the waste is disposed of, for which an indispensable asset is a disposal facility for LILW. During the decommissioning of a nuclear facility, significant quantities of mainly LILW are produced. The implementation of a well-functioning radioactive waste management program during the decommissioning of the facility depends primarily on the availability of enough storage space for the empty drums, casks, and other containers needed for the disposal or unconditional release of material (Laraia, 2012, p. 375). The IAEA estimates the mass of the decommissioning waste: a light-water reactor with $1 \mathrm{GW}_{\mathrm{e}}$ can be expected to produce 5,000 to 6,000 tons of LILW and 1,000 tons of long-lived LILW and HLW (IAEA 2007b). This estimate has to be taken with caution as only one reactor as big as $1 \mathrm{GW}$ e has been decommissioned worldwide yet but this reactor (Trojan in the US) was only operational for 17 years (see Section 5). Similar to operational waste, the quantity of decommissioning waste again depends on i.e. the reactor technology, the clearance level of waste, the decommissioning strategy, and the operating time.

\section{HIGH-LEVEL WASTE: REPROCESSING AND SPENT NUCLEAR FUEL (SNF)}

Concerning what exactly constitutes HLW depends on the national policy and on the nature of the fuel chain. In general, there are three different strategies for dealing with nuclear waste: the "Open Cycle", the "Closed Cycle" and the "Wait and See option" (IAEA 2002, 34). However, the term "cycle" is misleading, instead the term "nuclear fuel chain" is more accurate, as on the contrary, only a small part of the reprocessed material will reenter the fuel chain as fresh fuel. Only some of the separated plutonium is reintroduced into the fuel cycle through the fabrication of mixed oxide fuel rods (MOX) while the depleted uranium is in most cases stored and constitutes significant stockpiles. In addition, reprocessing spent nuclear fuel creates large quantities of LILW, meaning that the total volume of waste to be managed is much greater than if the spent fuel is treated directly as a waste (Besnard et al. 2019, 23).

After reprocessing, the residual fission products and actinides in liquid form are then evaporated and converted to solids by a vitrification process prior to intended further disposal. When SNF is not reprocessed, it has to be stored for about 40 years to allow cooling, first in the spent fuel pools, after this in an interim storage facility. In the latter, the storage process can either be "wet" in spent fuel pools or "dry" in casks made of concrete or reinforced steel. For the final disposal, the SNF is, depending on the waste management strategy, again transferred into the final disposal casks. This process is usually done under water. Table 11 gives an overview of the elementary processes and needed assets.

\footnotetext{
42 Waste compaction is also applied in order to minimize the waste quantities; compaction can be a part of conditioning but does not have to be. An additional category is conditioned waste that has to be reconditioned for safety or acceptance reasons or both. For example, bituminized sludges from reprocessing that AREVA client countries refuse to take back and that turn out sub-spec for final disposal in France. For more details on the waste production techniques, see Homberg, Pavageau, and Schneider (1997).
} 


\begin{tabular}{|c|c|c|}
\hline Elementary Process & Processes & Asset \\
\hline $\begin{array}{l}\text { Treatment and } \\
\text { conditioning of LILW }\end{array}$ & $\begin{array}{l}\text { Depending on the waste: } \\
\text { - } \quad \text { compaction } \\
\text { - } \quad \text { solidification } \\
\text { - } \quad \text { incineration } \\
\text { - } \quad \text { conditioning }\end{array}$ & $\begin{array}{ll}\text { - } & \text { waste treatment tools and } \\
\text { infrastructure } & \\
\text { - } & \text { casks, drums }\end{array}$ \\
\hline Storage of LILW & $\begin{array}{ll}\text { - } & \text { transport to interim storage facility } \\
\text { - } & \text { storage }\end{array}$ & $\begin{array}{ll}\text { - } & \text { nuclear transport logistics } \\
\text { - } & \text { interim storage facility }\end{array}$ \\
\hline Treatment of SNF & $\begin{array}{ll}- & \text { loading fuel into spent fuel pools } \\
\text { (immediate cooling) } \\
\text { - } & \text { loading fuel into storage/transport casks } \\
\text { - } & \text { transport of casks to interim storage facility } \\
\text { or reprocessing facility }\end{array}$ & $\begin{array}{ll}\text { - } & \text { spent fuel pool } \\
\text { - } & \text { storage/transport casks } \\
\text { - } & \text { interim storage facility } \\
\text { - } & \text { nuclear transport logistics }\end{array}$ \\
\hline $\begin{array}{l}\text { Interim storage of } \\
\text { SNF/HLW }\end{array}$ & $\begin{array}{ll}\text { - } & \text { wet or dry storage of SNF } \\
\text { - } & \text { storage of HLW }\end{array}$ & $\begin{array}{ll}\text { - } & \text { storage/transport casks } \\
\text { - } & \text { wet or dry interim storage } \\
\text { facility }\end{array}$ \\
\hline Reprocessing SNF & $\begin{array}{ll}\text { - } & \text { loading fuel into storage/transport casks } \\
\text { - } & \text { transporting SNF to reprocessing facility } \\
\text { - } & \text { extracting plutonium and uranium } \\
\text { - } & \text { vitrifying waste } \\
\text { - } & \text { conditioning waste } \\
\text { - } & \text { transporting waste back to waste producer }\end{array}$ & $\begin{array}{ll}\text { - } & \text { reprocessing facility } \\
\text { - } & \text { storage/transport casks } \\
\text { - } & \text { nuclear transport logistic } \\
\text { - } & \text { vitrification plant }\end{array}$ \\
\hline Disposing LLW & $\begin{array}{ll} & \text { conditioning waste } \\
\text { - } & \text { transporting waste to facility } \\
\text { - } & \text { disposing of waste } \\
\end{array}$ & $\begin{array}{ll} & \text { near-surface disposal facility } \\
\text { - } & \text { transport and disposal casks } \\
\text { - } & \text { nuclear transport logistic } \\
\end{array}$ \\
\hline Disposing ILW & $\begin{array}{ll}- & \text { conditioning waste } \\
\text { - } & \text { transporting waste to facility } \\
\text { - } & \text { disposing of waste }\end{array}$ & $\begin{array}{ll} & \text { belowground disposal facility } \\
\text { - } & \text { transport and disposal casks } \\
\text { - } & \text { nuclear transport logistic }\end{array}$ \\
\hline Disposing HLW & $\begin{array}{l}\text { - } \quad \text { conditioning waste } \\
\text { - } \quad \text { transporting waste to facility } \\
\text { - } \quad \text { disposing of waste }\end{array}$ & $\begin{array}{ll}\text { - } & \text { deep geological disposa } \\
& \text { facility } \\
\text { - } & \text { transport and disposal casks } \\
\text { - } & \text { nuclear transport logistic } \\
\end{array}$ \\
\hline
\end{tabular}

Table 11: Processes and Assets of the Technical System "Storage" and "Disposal".

Source: Own depiction.

The analysis leads to a picture of interdependent processes, which can be of a high degree of specificity, especially the disposal of ILW and HLW (although the construction of a deep geological repository for $\mathrm{HLW}$ has not yet been realized anywhere in the world). The technical system of nuclear waste management consists mainly of a high number of transformation, storage, and transfer processes, some of which are of course interlinked. An important technical interface, which needs coordination, is between the treatment, storage, and disposal processes, especially about the used containers or casks. Their design needs to be adjusted to the storage/disposal methods (interface 4 in Figure 9 ). Figure 9 lets us identify some other interfaces. Interdependencies between waste management and operations exist, too, as with the start of the first reactor operational waste and spent fuel is generated, which needs to be treated and stored (interface 1). A "new" interface, that attracts more attention and requires more coordination is the interface between decommissioning and storage (Scherwath, Wealer, and Mendelevitch 2020). When decommissioning starts, large quantities of waste are generated in rather short time which need to be either stored (interface 2) or disposed of (interface 3). Missing disposal facilities (or storage) can also hinder the decommissioning process or even render the regulatory release of the site impossible (interface 4, 5, see Section 5). 


\subsubsection{Tasks, roles, and actors}

In this step of the analysis, a role model can be set up, in which the major roles required for the analysis as well as the relationships between these roles are included. We focus here on the role type offer of elementary process, which primarily comprises the combined use of assets to perform elementary processes. All the tasks needed for the elementary processes of "treatment" of SNF or LILW could be handled by the nuclear utility itself or a dedicated waste management organization; both could be public or privately owned. An important actor is the provider of casks/drums etc. for the transport, storage, or disposal of nuclear waste. The waste management organization could also take over the task of "disposal" of LILW or HLW. Between such a waste management organization and a nuclear utility exists an ordering relationship, as the utility would order the services of storage or disposal. The respective national governments could also provide disposal. This would also be the case for the provision of the service "treatment", if the nuclear utility would not take over this task. Another possible actor would be private companies providing the services of "treatment", "storage", or "reprocessing". If this were the case, a substitutive relationship would exist between these possible providers.

\subsubsection{Organization models for the production of ...}

\subsubsection{1 ... low- and intermediate-level waste storage}

According to the World Nuclear Waste Report, disposal facilities for low-level wastes have been implemented in some countries for decades; mainly specific landfill disposal and engineered trenches, near surface disposal and belowground facilities. Although the early US landfills showed, that they were leaking, as plutonium complexes could be found outside the landfill; incidents happened, too. After this, the protective functions of the disposal facilities were reinforced with additional protections in the form of concreted components and structures (e.g. in the U.S, or France). Although, dilution also happens at these facilities, as small radioactive substances can also be washed out from these facilities. Belowground facilities for LILW were constructed in e.g. Sweden, and France, while in Spain (EI Cabril) and the Czech Republic mines are used for disposal of LILW.

The majority of low- and intermediate-level waste disposal facilities are constructed and operated by state agencies or public companies (e.g., Andra in France; Enresa in Spain; BGE in Germany; Radioactive Waste Management Ltd (RWM), which is owned by the public body NDA, in the UK). In some cases, the waste management organization is a private company. In Sweden, for instance, the utilities have created the private company SKB, the Swedish Nuclear Fuel and Waste Management Company, to operate the disposal facilities. The situation in the U.S. is very complex, disposal of LLW has to be managed on a state-level, while managing HLW is a federal issue. In the U.S., some private companies are operating disposal facilities, among them EnergySolutions, a major nuclear waste management company (i.a. Sovacool and Funk 2013; Besnard et al. 2019).

\subsubsection{2 ... reprocessing}

As reprocessing means the extraction of plutonium, there is no real "civil" or "private", provider of reprocessing services and all reprocessing service providers are state-controlled. Western countries had to send or still send their SNF abroad for reprocessing to either France, or the UK, while Russia (and the USSR) provided this service to a few central European countries, which used Soviet-designed 
reactors for electricity generation. In 2018, the THORP facility in the UK ceased operations ${ }^{43}$, leaving La Hague in France as the last commercial reprocessing plant in Western Europe. Orano has a monopoly position and has thus with the exception of disposal of nuclear waste services fully integrated the nuclear front- and back-end in its firm. The same holds true for Atomenergoprom, part of Rosatom.

Reprocessing contracts are settled through long-term contracts. One reason is the long period from unloading of SNF from the reactor core, through reprocessing, MOX fuel fabrication, and return of vitrified waste; another is the high specificity and costs for commissioning of a reprocessing plant (OECD/NEA 2008, 84). In Europe, reprocessing is still done in France, the Netherlands, and Russia, although most countries have suspended or stopped it, mainly for economic reasons (Belgium, Bulgaria, Germany, Hungary, Sweden, Switzerland, UK) (Besnard et al. 2019). ${ }^{44}$

\subsubsection{3 ... high-level waste storage}

The final disposal of high-level waste is normally the responsibility of a special government agency or other approved body established for this purpose (OECD/NEA 2008, 91). There are exceptions to this, for instance, in Sweden and Finland the nuclear utilities created a private company for managing SNF (interim and disposal) (Brunnengräber et al. 2015). As there is still no disposal facility available worldwide, interim storage issues are coming to the fore. Interim storage is often the scope of the utilities, while the disposal is in the hands of the national governments. In the majority of the countries, SNF is stored in a decentralized way, mostly at the reactor site, either in casks (dry storage), or in spent fuel pools. As of 2016, 81 percent of Europe's SNF is still in wet storage; although it would be safer to transfer it into dry storage (Besnard et al. 2019). In Sweden and Finland, the private waste management companies operate a centralized wet storage facility. In Germany, the utilities have built interim storage facilities on the reactor site to store their SNF. The status of the latter was changed in 2016 with a new law, that transferred inter alias the ownership of the interim storage facilities to the federally owned company for interim storage (BGZ). ${ }^{45}$

An important actor in the waste management services are the cask producers. These casks are made of metal and are in use in the majority of European countries. The main actors are the German utilitiesowned GNS (Gesellschaft für Nuklear-Service $\mathrm{mbH}$ ), which produces the CASTOR casks, French Orano, and US Holtec International.

As disposing with nuclear waste is mostly a national matter and done by in the majority of the cases by state-controlled companies or public bodies, there is no real competition in this value-added stage. There is some competition with regard to specialized waste management companies providing casks or conditioning services. The forthcoming process of final disposal is dominated by the state worldwide and places special demands on regulators due to multiple principal-agent problems.

\footnotetext{
${ }^{43}$ Government of the UK. 2018. "End of reprocessing at Thorp signals new era for Sellafield." Accessed June 12, 2019. https://www.gov.uk/government/news/end-of-reprocessing-at-thorp-signals-new-era-for-sellafield.

44 The latest European country to show interest in reprocessing is Ukraine, which signed a contract for a feasibility study with France's Orano.

45 In the coming years, the LILW storage facilities on the reactor sites will also be transferred to the public company.
} 


\section{In-depth analysis: Reactor decommissioning}

In this section an in-depth analysis of the process, "decommissioning of nuclear power plants" with reference to the interfaces to the system good "waste management"; especially in respect to "interim storage" and "final disposal" of waste is carried out. Section 5.1 describes the system good of decommissioning nuclear power plants. In section 5.2 the system good of decommissioning nuclear power plants is mapped out in the framework. Section 5.3 introduces three case studies, where the organizational models for decommissioning in United Kingdom, United States of America, and Germany are described.

\subsection{Description of the system good}

The decommissioning of nuclear power plants is technically complex and poses major challenges for operators and regulation. ${ }^{46}$ The IAEA (2007) defines decommissioning as technical and administrative measures taken to allow the removal of some or all regulatory controls from an installation. These technical measures include all the necessary processes leading to the release of a nuclear installation. However, an installation can be decommissioned without being dismantled. In that case, the existing structures are subsequently put to another use. The term decommissioning implies that no further use of the installation (or part of it) is intended for the existing purpose (IAEA 2007c).

There are two basic strategies for the decommissioning of nuclear power plants: Immediate dismantling (ID) and long-term enclosure (LTE, sometimes called "safe enclosure"). ${ }^{47}$ In the case of immediate dismantling, the plant is disconnected from the grid, and decommissioning starts immediately after the end of the post-operational phase, which can last several years, on average three to five years. Both strategies have advantages and disadvantages. In case of immediate dismantling, the skills, specific (plant) knowledge and experience of the operating personnel can be used for the decommissioning process. After grid disconnection, there is still a clear line of responsibility and a certain public interest in the decommissioning process; a further advantage is that the plant can be removed from regulatory control relatively soon. A disadvantage of this approach is the radiation hazard involved in dismantling the contaminated or activated parts, which places special safety requirements on the personnel but also on the tools used.

The long-term enclosure of a nuclear power plant can extend over several decades, thus reducing the residual radioactivity caused by radiological decay. However, there is a risk that 40,60 (e.g. U.S.), or 85 (e.g. U.K.) years after the shutdown of the plant, most of the expertise about the site will be lost. Another potential advantage of this strategy is that technical improvements in the future may lead to a reduction in hazard and costs. On the other hand, experience has shown that the costs of monitoring and maintenance during long-term containment are not negligible. In practice, a hybrid dismantling

\footnotetext{
${ }^{46}$ This section is largely based on own publications by the authors, i.a. the chapter "Decommissioning Status Report" in the World Nuclear Industry Status Report (Schneider et al. 2018, 2019); Wealer, Seidel, and Hirschhausen (2019); Scherwath, Wealer, and Mendelevitch (2020), Wealer et al. (2015), and Seidel and Wealer (2016).

$47 \mathrm{~A}$ third, but rarely used strategy is "entombment", i.e. the "burial" of the nuclear power plant; here radioactive contaminants are permanently enclosed on site in materials such as concrete. In the U.S., this strategy has been used for three reactors.
} 
strategy is also encountered, as a hybrid of immediate dismantling and long-term enclosure; here, large components such as the activated reactor pressure vessel are transported to an interim storage facility for several decades to decay, while the rest of the plant is immediately dismantled.

In mid- 2019, 162 reactors worldwide were in the various decommissioning stages. However, only 19 reactors have completed the technical decommissioning process (Figure 7). Together, these 19 reactor have a combined capacity of only about $6 \mathrm{GW}_{\mathrm{e}}$, which is about 8 percent of the total of 78.1 $\mathrm{GW}_{\mathrm{e}}$ taken off the grid. Only one large power reactor above $1 \mathrm{GW}_{\mathrm{e}}$ of capacity has been decommissioned worldwide, but this reactor (Trojan in Oregon, USA) has only been in operation for 17 years. Of the 19 decommissioning projects closing, only ten have been completely released from regulatory control, while only ten reactors have been completely decommissioned to greenfield sites. The average duration of the decommissioning process, regardless of the decommissioning strategy chosen, is about 19 years with a very high variance: the minimum of six years for the $22 \mathrm{MW}_{\mathrm{e}}$ Elk River power plant and the maximum of 42 years for the $17 \mathrm{MW}$ CVTR (Carolinas-Virginia Tube Reactor), both in the U.S. ${ }^{48}$

The only countries that have completed the decommissioning process are the United States (13), Germany (5), and Japan (1). Some of the US reactors are among the fastest decommissioned, such as Fort St. Vrain, Shippingport, Elk River, Maine Yankee and Shoreham (where the reactor building was converted to house a gas turbine plant); however, the average duration was still 16 years and the process took over two decades for Pathfinder and CVTR (both of which were never commissioned) and over two decades for Saxton. In Germany, the HDR (superheated steam reactor) Großwelzheim was only on line for one year, but decommissioning took well over 20 years. Gundremmingen-A and Würgassen have de facto completed the technical decommissioning process, but cannot be released from nuclear regulatory control, as the buildings are used for the interim storage of waste or for conditioning work. In Japan, only a small research reactor has been decommissioned, while none of the commercial reactors has been dismantled to date. Table 12 gives an overview of the 19 (technically) decommissioned power plants.

\footnotetext{
${ }^{48}$ For more details see Schneider et al. $(2018,2019)$.
} 


\begin{tabular}{|c|c|c|c|c|}
\hline Country & Reactors & Capacity in $\mathrm{MW}_{\mathrm{e}}$ & $\begin{array}{c}\text { Decommissioning } \\
\text { End }\end{array}$ & $\begin{array}{l}\text { Operational } \\
\text { time in years }\end{array}$ \\
\hline \multirow[t]{6}{*}{ Germany } & 5 & 1,017 & & \\
\hline & Niederaichbach & 100 & 1995 & 1 \\
\hline & HDR Großwelzheim & 25 & 1998 & 2 \\
\hline & VAK Kahl & 15 & 2010 & 24 \\
\hline & Würgassen & 640 & 2014 & 23 \\
\hline & Gundremmingen- $\mathrm{A}$ & 237 & 2016 & 11 \\
\hline \multirow[t]{2}{*}{ Japan } & 1 & 12 & & \\
\hline & JPDR & 12 & 2002 & 13 \\
\hline \multirow[t]{14}{*}{ USA } & 13 & 4,992 & & \\
\hline & Elk River & 22 & 1974 & 5 \\
\hline & Shippingport & 60 & 1989 & 25 \\
\hline & Pathfinder & 59 & 1993 & 1 \\
\hline & Shoreham & 809 & 1995 & 0 \\
\hline & Fort St. Vrain & 330 & 1997 & 13 \\
\hline & Maine Yankee & 860 & 2005 & 24 \\
\hline & Saxton & 3 & 2005 & 5 \\
\hline & Trojan & 1,095 & 2005 & 17 \\
\hline & Yankee NPS & 167 & 2006 & 31 \\
\hline & Big Rock Point & 67 & 2006 & 35 \\
\hline & Haddam Neck & 560 & 2007 & 29 \\
\hline & Rancho Seco-1 & 873 & 2009 & 15 \\
\hline & CVTR & 17 & 2009 & 4 \\
\hline Total & & 5,951 & & \\
\hline
\end{tabular}

Table 12: Decommissioned reactors worldwide, as of July, 2019.

Source: Schneider et al. (2018), and Besnard et al. (2019).

In general, decommissioning takes much longer than expected, in some cases even longer than construction and operation combined (see Figure 7). The decommissioning work initially started with the simplest projects, since almost all of these reactors are more or less small prototype or demonstration reactors of low power (i.e. first generation reactor), which have not been operated for a long time and therefore have a smaller radiological inventory. The decommissioning of the oldest reactors has in most cases not even started and faces particular technical and organizational challenges. In particular, the graphite-moderated, gas-cooled reactors (GCRs) in the U.K. Britain and France are to be decommissioned for decades to come. Most nuclear countries are just only implementing organizational models for decommissioning, while experience with decommissioning reactors of the second generation of nuclear reactors, i.e. large-scale (over $1 \mathrm{GW}$ ) reactors that operated for 30 to 40 years does not yet exist. 


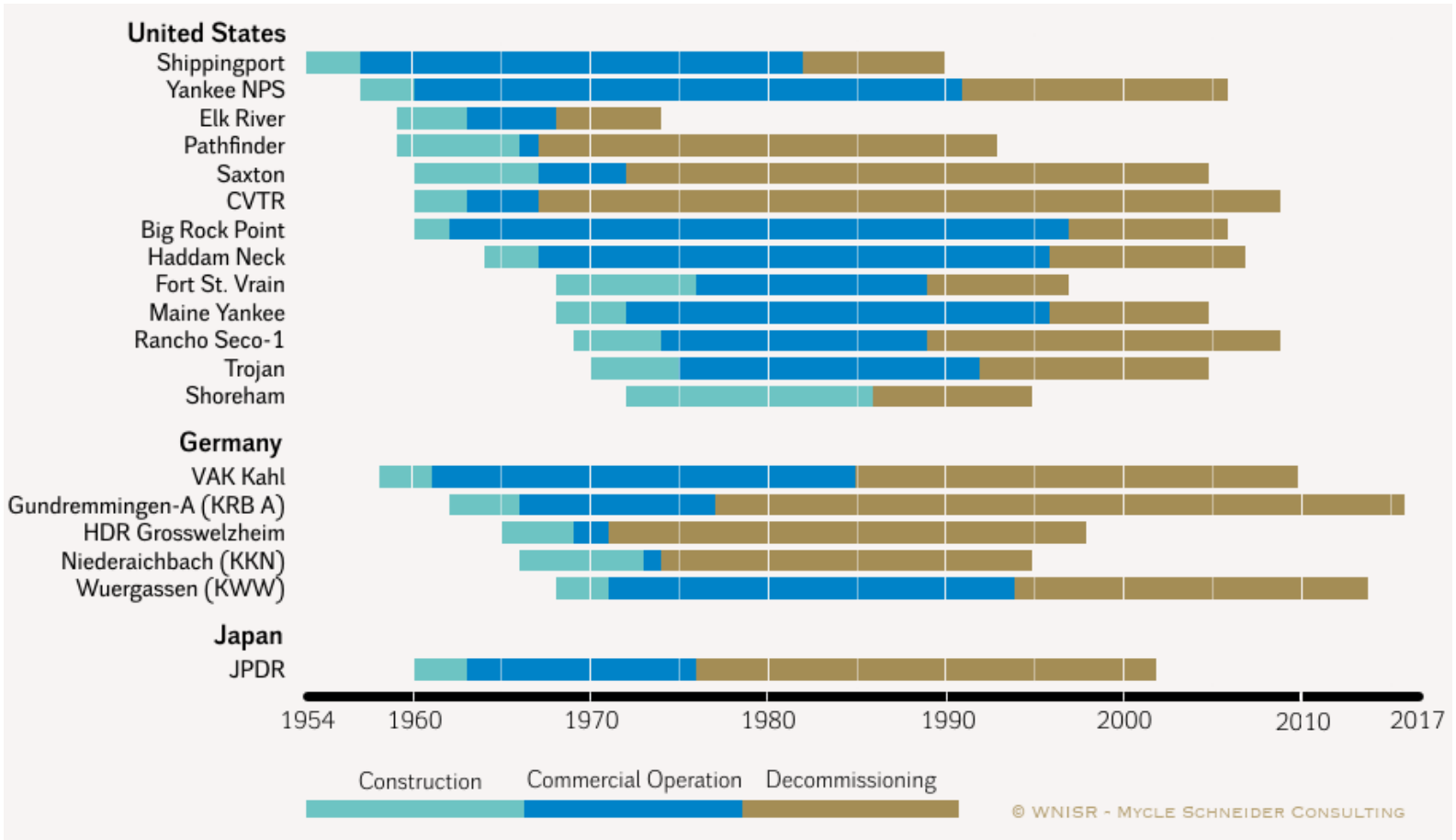

Figure 7: Overview of completed reactor decommissioning projects, 1953-2017.49

Source: Schneider et al. $(2018,135)$.

\subsection{Mapping of the system good "decommissioning" in the analysis framework}

\subsubsection{Description of the technical system}

\subsubsection{Three stages: Warm-up, hot-zone, and ease-off}

In general, the technical decommissioning process moves from the "outer" to the "inner" areas of the reactor and can be divided into three sequential and thus temporally complementary stages for simplification: the "warm-up stage", the "hot-zone stage" and the "ease-off stage" (Schneider et al. 2018):

- The warm-up stage includes the post-operational phase, which is the first phase of the decommissioning process and starts with the closure of the reactor. Here, the spent nuclear fuel (SNF) is unloaded from the reactor core and transferred to the spent fuel pools. SNF needs around three to five years to cool off before it can be transferred into storage and transportation casks and moved into an on-site (i.e. decentralized) or a centralized interim storage facility. The complete defueling of the reactor core and the spent fuel pools reduces the level of risk as the

\footnotetext{
49 Note: The green bars represent the construction period, blue bars commercial operation, and brown bars the post-operational phase with the end of the decommissioning process. In most cases, the decommissioning process (in brown) takes longer than construction (in green) and commercial operations (in blue) combined.
} 
radiological inventory decreases largely ${ }^{50}$ and is therefore an indicator for the progress of the warm-up stage, as this is crucial for the further efficient production of the dismantling work, although it is not a necessary condition for starting dismantling work. Depending on the regulatory framework, operational waste can also be removed in the post-operational phase, as well as the decontamination of systems and components. Since the post-operational phase can last several years and the transition from operation to the post-operational phase and then to decommissioning is not always clearly recognizable or regulated differently depending on the national institutions ${ }^{51}$, we assign the post-operational phase to the warm-up stage. ${ }^{52}$

- The hot-zone stage comprises the dismantling processes in the controlled area of the nuclear island, which means above all the dismantling of highly contaminated or activated parts, for example the reactor pressure vessel (RPV), the reactor vessel internals, or the biological shield. In addition, it is useful to distinguish between the possibilities of cutting up the pressure vessel on site or removing it in one piece from the reactor building and later dismantling it (hybrid strategy) or even disposing of it in one piece (see the following case study on the U.S.). This stage is the most demanding stage in terms of safety precautions but also in terms of specific assets required carrying out the dismantling work, e.g. remote-controlled manipulators can be used under water to dismantle the pressure vessel.

- The ease-off stage includes the removal of the operating systems and the decontamination of the buildings. This stage ideally ends with the demolition of the buildings and defines the end of the technical decommissioning process - actual technical decommissioning works were completed. Depending on the national institutions, buildings do not necessary need to be demolished, if the later release as a "brownfield" is allowed. When the technical process is completed, the reactor enters the "regulatory release" stage, where the site awaits the regulatory release. Again, depending on the national institutions, the site can be released as a greenfield, brown field or in some cases the license can be reduced, e.g. in the U.S., to a license covering the remaining spent fuel storage installations. Brownfield use is allowed in some countries, which means that the buildings can continue to be used for nuclear and other purposes. Figure 8 gives an overview of the decommissioning strategies and stages

\footnotetext{
${ }^{50}$ After closure of the reactor, the fuel elements have an activity of about $10^{20}$ to $10^{21} \mathrm{~Bq}$. In a large nuclear power plant, the following activity levels remain: about $10^{16} \mathrm{~Bq}$ in the form of activated material near the reactor core, about $10^{12} \mathrm{~Bq}$ in the form of contamination on the inner surfaces of circuits and about $10^{10}$ to $10^{11} \mathrm{~Bq}$ in the form of contamination on surfaces of components or buildings (Thierfeldt and Schartmann 2009, 4, own translation).

${ }^{51}$ In some countries the post-operational phase is covered by the operating license (e.g. Germany), while in others a specific license must be applied for.

52 The warm-up stage also includes the dismantling of systems that are not required for the actual dismantling process and the installation of logistics in the control area of the reactor. The dismantling of more highly contaminated plant components also begins, for example, steam generators or parts of the primary cooling circuit can already be dismantled.
} 


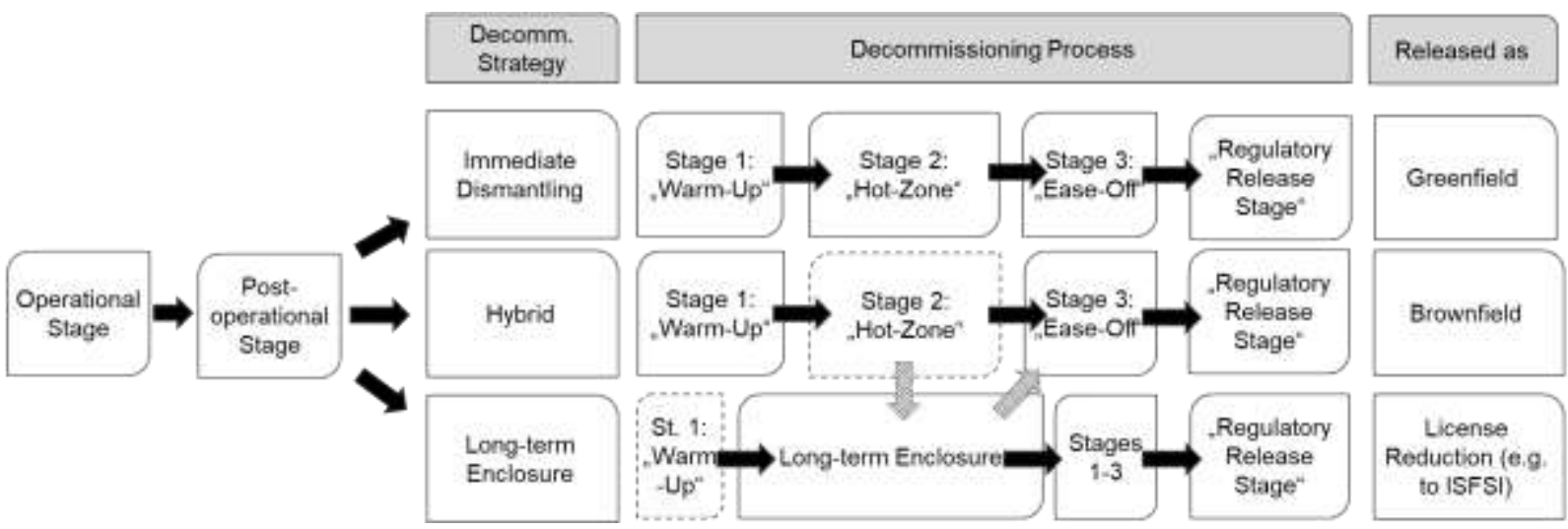

Figure 8: Decommissioning Strategies and Stages.

Source: Own depiction.

\subsubsection{Processes and assets}

Table 13 provides an overview of the main processes and the assets required for decommissioning. $\mathrm{A}$ crucial process during decommissioning is the dismantling of the reactor island, which requires highly specific resources in terms of assets for performing the process as well as reactor knowledge. Overall, the processes in the hot-zone stage are particularly demanding due to the highest requirements in radiation protection and the need of highly specific tools, e.g. as some of the works are executed under water or with the help of manipulators. For instance, during the decommissioning of the German nuclear power plant Stade (still on going), it turned out that nearly all tools used in the hot-zone stage had to be designed especially for this purpose..$^{53}$ Transport or storage containers or, more generally, a storage or disposal infrastructure is required in all stages of decommissioning. Thus, the lack of disposal facilities can impede the process of immediate dismantling and requires coordination beyond the value-added stages 53 Loeb, Andreas. 2011. "RDB Rückbau im Kernkraftwerk Stade: Innovative Umsetzung." atw - Internationale
Zeitschrift für Kernenergie 56 (3): 171-175. 


\begin{tabular}{|c|c|c|}
\hline Stage & Processes & Assets \\
\hline Stage 1: Warm-Up & $\begin{array}{l}\text { - } \quad \text { Defueling of the reactor core and the spent } \\
\text { fuel pools } \\
\text { - } \quad \text { Decontamination work } \\
\text { - } \quad \text { Dismantling of first redundant systems } \\
\text { - } \quad \text { Dismantling of higher contaminated plant } \\
\text { components (e.g. steam generator and } \\
\text { parts of the primary cooling circuit) } \\
\text { Conditioning work of operational wastes } \\
\text { and spent fuel (Loading the spent fuel into } \\
\text { storage casks) }\end{array}$ & $\begin{array}{ll}\text { - } & \text { Transport and storage casks } \\
\text { - } & \text { Decontamination tools } \\
\text { - } & \text { Transport logistic } \\
\text { - } & \text { Logistic for handling hot-zone } \\
\text { - } & \text { Inork } \\
\text { - } & \text { Disposal facility (or access to) }\end{array}$ \\
\hline Stage 2: Hot-Zone & $\begin{array}{l}\text { - Dismantling of the reactor pressure vessel } \\
\text { - Dismantling of the reactor pressure vessel } \\
\text { internals } \\
\text { - Dismantling of the biological shield } \\
\text { Dismantling of the cooling circuit }\end{array}$ & $\begin{array}{ll}\text { - } & \text { Transport and storage casks } \\
\text { - } & \text { Decontamination tools } \\
\text { - } & \text { Transport logistic } \\
\text { - } & \text { Logistic for handling hot-zone } \\
\text { - } & \text { Inork } \\
\text { - } & \text { Highly specific tools for reactor } \\
& \text { dismantling (e.g., under water } \\
& \text { manipulator) } \\
\end{array}$ \\
\hline Stage 3: Ease-Off & $\begin{array}{ll} & \text { Removal of operating systems } \\
\text { - } & \text { Decontamination of the buildings } \\
\text { - } & \text { (ideally) the demolition of the buildings } \\
\text { - } & \text { Conditioning works } \\
\text { - } & \text { Site remediation }\end{array}$ & $\begin{array}{ll}\text { - } & \text { Transport and storage casks } \\
\text { - } & \text { Decontamination tools } \\
\text { - } & \text { Transport logistic } \\
& \text { Logistic for handling hot-zone } \\
\text { - } & \text { Interk } \\
\text { - } & \text { Disposal facility (or access to) } \\
\end{array}$ \\
\hline
\end{tabular}

Table 13: Processes and Assets of the Technical System “Decommissioning”.

Source: Own depiction.

Figure 9 provides an overview of the interfaces between the value-added stage "decommissioning" and the value-added stages "operation", "interim storage" and "final disposal". Already during operation, the final decommissioning plan must be established and applications submitted to the respective regulatory authorities. A well-functioning nuclear waste management program or access to such a program is crucial asset of the decommissioning process and has interfaces to all decommissioning stages. The various types of waste from the operating and decommissioning phases of the NPP must be stored according to their radiological properties and their ability to dissipate heat. There is a significant need for coordination between decommissioning and waste management. During the decommissioning process, considerable amounts of radioactive waste are generated which have to be disposed or stored temporarily (interface 2 and 3 ). In order for a site to be completely released from regulatory control, the site must be free of waste, which means that there must be no interim storage at the site (interface 4). Disposal facilities for decommissioning wastes (low-and intermediate-level wastes) exist in some countries (e.g., France, Spain, the U.S.), which may facilitate an immediate dismantling of the reactor. However, other countries do not have waste disposal sites or are confronted with having to decommission reactor technologies, that are either complicated to dismantle or where decommissioning generates wastes, that have not yet a disposal solution. Here long-term enclosure is the preferred strategy. For instance, the gas cooled and graphite moderated reactors (GCRs) largely employed in France and the U.K., where the decommissioning process will last well into the $22^{\text {nd }}$ century. 


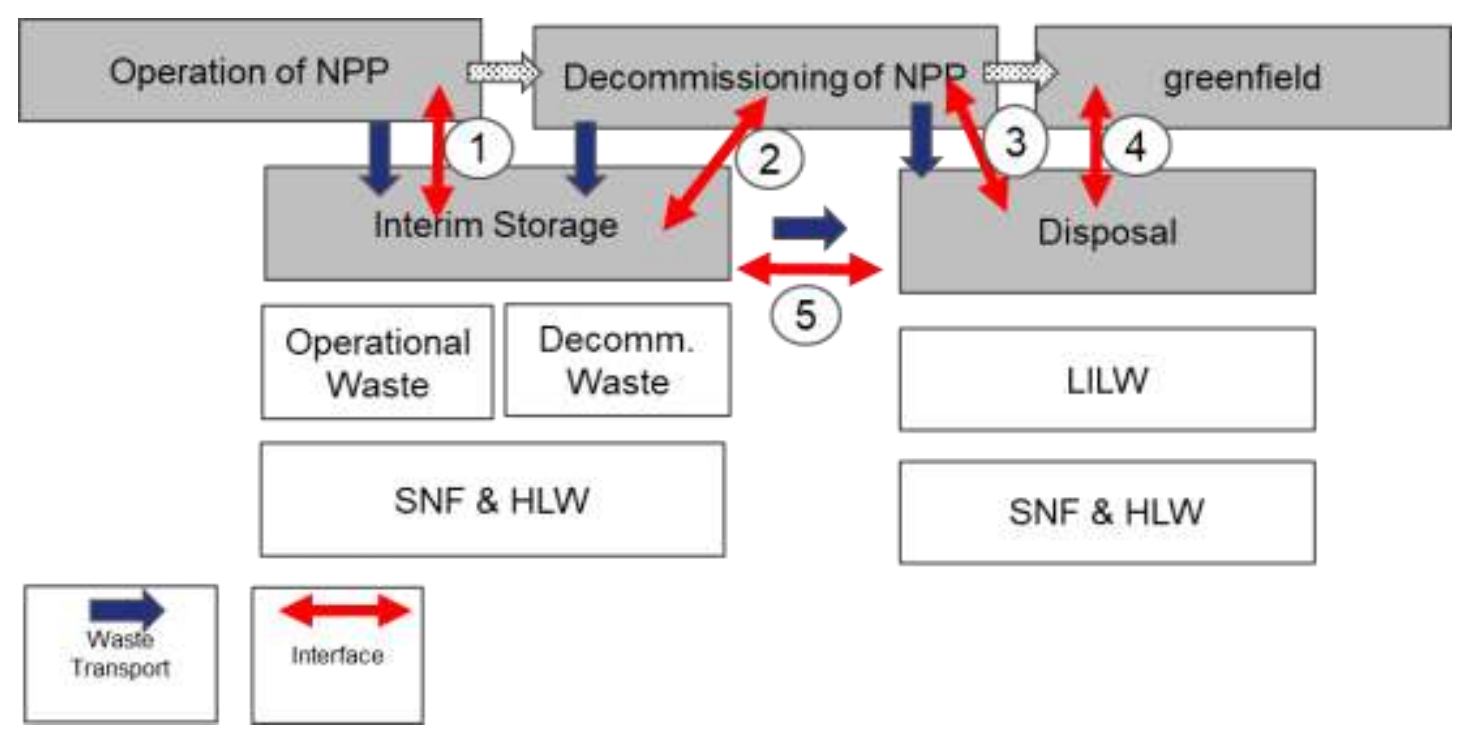

Figure 9: The Decommissioning Processes and the Interfaces to the Processes "Operation", "Interim Storage", and "Final Disposal".

Source: Own depiction.

\subsubsection{Tasks, roles, and actors}

Based on the description of the processes and assets needed for the technical system of "decommissioning" tasks, roles, and actors can be derived. As there are manifold tasks involved, we focus only on a few roles, which deserve further attention. The following actors as well as their tasks and interactions need further attention. This list is of course only tentative but nonetheless some roles and relationships can be identified.

To start with, the "easiest" one, where a substitutive relationship is expected is the role of providing "conventional demolishing works". As most parts of a nuclear installation never become radioactive during operation, they can be dismantled or removed by conventional methods (Laraia 2012b, 14). Overall, the actors in the decommissioning process can be public, private or a mixture of both. In general, the licensee (private or (semi-)public) is responsible for all aspects of decommissioning of a nuclear reactor. Although, the licensee may delegate some tasks to other organizations, especially tasks or processes, which require highly specialized tools and expertise, to private or public companies. Hence, one of the first strategic choices for the licensee, which has a significant impact on the project organization, is to decide on the scope of work to be carried out internally. Cacuci $(2010,3007)$ distinguishes between two approaches. Either decommissioning is carried out with internal resources, supplemented where necessary by specialist contractors; or the licensee concludes contracts with an experienced external organization to carry out the decommissioning activities and provide general supervision and support services. In some countries, the legal responsibility for decommissioning is also transferred to a specific organization after final closure. This may be a governmental organization (ENRESA in Spain) or a private company (decommissioning companies in the U.S). In these cases, this organization becomes the new licensee of the plant. 
As decommissioning poses possible hazards to the public and the environment, it is subject to specific relevant laws and policies. Therefore, an important actor is the regulatory authority, which has the task to i.e. assess the decommissioning proposals, to monitor compliance with all aspects of the implementation, to ensure that requirements relating to the safety (e.g., site personnel, public) are met at all stages of decommissioning. The regulatory authority may also impose a time limit on the decommissioning process. For instance, in France, where immediate dismantling is the defined decommissioning strategy, decommissioning works have to be carried out, as fast as possible.

\subsection{Three country cases studies and their organizational models}

This section introduces the organizational models for the decommissioning processes in the United Kingdom, United States of America, and Germany. These three countries have chosen very different organizational models in various forms. The respective national decommissioning strategies for production range from a specific national decommissioning strategy to a relatively free choice of strategy for the plant operators. The U.K. had tried to tender the dismantling of its Magnox reactors to a special purpose company, but this approach failed. Now production is the responsibility of a governmental agency. The U.S. uses various models, including private decommissioning companies that seek economies of scale by taking over several reactors. In general, there are major regulatory challenges to which the authorities must adhere and a high degree of information asymmetry with regard to the operating companies.

\subsubsection{United States of America}

\subsubsection{Decommissioning status}

The U.S. has both, the highest number of closed reactors (36 reactors, as of May 2019) as well as the most decommissioned reactors. In the near and medium future, dismantling in the U.S. is facing major challenges, with at least 100 reactors to be dismantled from 2050 onwards. This against the background of low electricity prices, which are further burdening the competitiveness of nuclear power plants, and low provisions for decommissioning and waste management by the companies (Wealer et al. 2017). Of the 36 reactors 13 units or $4.9 \mathrm{GW}_{\mathrm{e}}$ have been decommissioned (Table 14). 11 units, where decommissioning work is currently being performed, of which six reactors are in the warm-up stage and five reactors are in the ease-off stage (Schneider et al. 2019). The U.S. has also a large number of reactors in long-term enclosure ( 12 units or $3.6 \mathrm{GW}$, including three reactors in entombment). The LTE period is limited to 60 years, after which the reactor has to be decommissioned. 


\begin{tabular}{|c|c|c|}
\hline United States of America & May 2018 & May 2019 \\
\hline "Warm-up-stage" & 4 & 6 \\
\hline of which defueled & 1 & 1 \\
\hline "Hot-zone-stage" & 0 & 0 \\
\hline "Ease-off-stage" & 5 & 5 \\
\hline LTE & $12^{54}$ & 12 \\
\hline Finished & 13 & 13 \\
\hline of which greenfield & 6 & 6 \\
\hline Shut-down reactors & 34 & 36 \\
\hline
\end{tabular}

Table 14: Current Status of Reactor Decommissioning in the U.S. (as of May 2019).

Source: Schneider et al. $(2018,2019)$.

The earliest decommissioning project as well as the earliest application of underwater segmentation of reactor vessel internals was performed at Elk River. The reactor internals were segmented under water using a remotely controlled plasma arc torch system, developed by the Oak Ridge National Laboratory (LaGuardia 2012, 520). During the ease-off stage explosives were used for the demolition of concrete buildings (Delaney 1985, 32).

Fort St. Vrain, a $330 \mathrm{MW}$ e high temperature gas cooled reactor, located to the North of Denver, was shut down in 1989, after 13 years of operation. This constitutes the first decommissioning of a gas-cooled reactor. The operator, the Public Service Company of Colorado, chose to immediately dismantle the reactor. Reactor dismantling was done on a fixed-price contract between the owner, and a team of Westinghouse and Morrison-Knudsen. Fisher (1998), a member of the Public Service Company of Colorado, gives a detailed report on the decommissioning project. In order to defuel the reactor, an independent spent fuel installation (ISFSI) was built, where the graphite fuel elements are stored vertically in steel canisters. The reactor was dismantled underwater using among others diamond wire cutting cables. In addition, more than 5,000 graphite blocks needed to be removed from the reactor. The waste from the reactor dismantling as well as the graphite blocks were shipped of as low-level waste to the Richland disposal facility (Fisher 1998). In 1996, the plant was converted to a natural gas power plant using the old steam turbine; conversion as a strategy for decommissioning was at that time endorsed by then US AEC (now NRC) (Laraia 2012c, 496-497).

The second decommissioned reactor was the demonstration reactor Shippingport, a $60 \mathrm{MWe}$ pressurized water reactor. The reactor was closed in 1982 after 25 years of operation. The project was used by the DOE to demonstrate the "safe and cost-effective" dismantling of a "commercial scale" nuclear power plant (Cumo 2010, 3026) and to demonstrate the one-piece vessel removal concept. ${ }^{55} \mathrm{In}$ 1985 , defueling was completed and the DOE started with the actual dismantling of the plant. As a demonstration reactor constructed under the auspices of the AEC (predecessor to the DOE), this meant that the DOE was obligated to fund and carry out decommissioning (Murphie 1991, 120). The 1,000 ton reactor pressure vessel was taken out in one piece with the uncut internals placed into the vessel and shipped (using the vessel as shipping container) from Pennsylvania, down the Ohio and Mississippi

\footnotetext{
54 Of which 3 reactors are in "Entombment": the DOE-reactors Piqua (OH), Bonus (Puerto Rico), Hallam (NE).

55 https://www.osti.gov/servlets/purl/6021025
} 
rivers, through the Panama Canal, up the Pacific coast, and into the Columbia River to the Hanford site (Steele 1989). This was supposed to be the most cost effective method, as there is minimal cutting of components, minimal handling, and the lowest waste volume generation as well as the lowest personnel exposure (LaGuardia 2012, 539). As the DOE was responsible for carrying out decommissioning, the project had access to federal radioactive waste disposal facilities (Murphie 1991, 120). In 1989, seven years after shutdown, the reactor components and buildings were completely dismantled; except for the turbine-generator systems, all vestiges of the facility were removed and the site was returned to a greenfield status (LaGuardia and Murphy 2012, 54).

The first reactor to complete the technical decommissioning process with a longer operating period was Big Rock Point Point, a 67 MW GE BWR in Michigan. The reactor was closed in 1997, after 35 years of operation. During the hot-zone stage the reactor vessel was removed in one piece after the internals were segmented and stored on site as GTCC waste (Laraia 2012a, 519). The removal of the RPV was awarded to BNFL, who teamed up with Siempelkamp (then MOTA corporation) and Sargent \& Lundy (Papp, Milner, and Slimp 2002). The goal of the operator CE was to release the site for unrestricted use. All systems and structures not needed for the independent spent fuel storage installation (ISFSI), except the intake piping and sanitary drainfield, have been removed. All SNF was transferred to the ISFSI by 2003. Two years later, the turbine building was demolished and final survey occurred during summer, 2005. The containment shell was removed in mid-200656 and decommissioning ended in 2006 (OECD/NEA 2016, 27). The site is a greenfield (Tompkins 2006) but a dry fuel storage facility was installed on site and will remain until the DOE accepts spent fuel. The change of strategy towards a greenfield state changed during decommissioning, when the operator found out that the real estate value $^{57}$ of the land below the reactor was more valuable than originally anticipated (LaGuardia 2012, 555).

The first larger reactor (over $1 \mathrm{GW}$ ) to complete decommissioning was Trojan, a 1,095 $\mathrm{MW}_{\mathrm{e}} \mathrm{PWR}$, closed in 1992, after 17 years of operation by Portland General Electric Co., 23 years before its operating license expired. For the Trojan plant, dismantling was undertaken by the utility itself. Steam generators were removed, transported, and the reactor vessel was removed and transported to the Hanford disposal site (Cacuci 2010, 3026). The internals were segmented under water and stored on site as GTCC wastes along with the SNF (LaGuardia 2012, 518). Although, decommissioning ended in 2005, the turbine building and all turbine-generator equipment was abandoned on site until additional future funding could be accumulated. However, the newly constructed administration building was converted to office space, and rented to local companies (LaGuardia 2012, 555).

Rancho Seco, a 918 MWe Babcock and Wilcox PWR in California, was shut down in 1989 after 15 years of operation by the Sacramento Municipal Utility District, 25 years before its operating license expired. Until 2008, the reactor was in LTE, in order to make decommissioning funds available (Cacuci 2010, 3026). The reactor vessel was too large and heavy to transport it over the local roads, so the vessel was

\footnotetext{
${ }^{56}$ NRC. 2015. "Big Rock Point." Accessed June 15, 2020. https://www.nrc.gov/info-finder/decommissioning/powerreactor/big-rock-point.html.

57 The site was located on some of the highest value real estate adjacent to Lake Michigan (LaGuardia 2012, 555).
} 
segmented and shipped in sections for disposal; the reactor vessel components were segmented and the GTCC pieces stored in the ISFSI, while the majority of the LLRW generated during decommissioning has been disposed at EnergySolutions (See LaGuardia 2012, 519-529 for more details). The segmentation work was done by Siempelkamp (then MOTA corporation). ${ }^{58}$ Although, decommissioning was completed in 2009, 30 years after being disconnected from the grid, the site is not yet released a greenfield. A storage building for low-level radioactive waste and an ISFSI will remain under NRC license. Sacramento Municipal Utility District will remain responsible and liable for the waste management. Table 15 gives an overview of the 13 decommissioned reactors in the U.S and informs about the decommissioning duration, license status and how the works in the hot-zone stage were carried out.

For the 13 decommissioned reactors, dismantling was completed on average 14 years after the reactor was finally shut down. One reason for these short decommissioning times is that in most cases the pressure vessel was removed and disposed of intact (see Table 15). In some cases, this was also done for other large components such as the steam generators.

Finally, as in other countries exploring decommissioning, one of the largest hurdles is the disposal of used nuclear fuel and nuclear waste as facilities continue to host waste on-site preventing the release as a greenfield (Rosner and Lordan 2014). The U.S. case study clearly illustrates the need for coordination between decommissioning and waste management. Of the 13 reactors that finished the technical decommissioning process, only six have been released from regulatory control, while for seven sites the license was reduced to the ISFSI.

58 http://www.radjournal.com/news_releases/Mota/Rancho\%2006.pdf 


\begin{tabular}{|c|c|c|c|c|c|c|c|c|}
\hline $\begin{array}{l}\text { Reactor } \\
\text { Name }\end{array}$ & $\begin{array}{l}\text { Reacto } \\
\text { r Type }\end{array}$ & $\begin{array}{c}\text { Capacity } \\
{[\mathrm{MW}]}\end{array}$ & $\begin{array}{l}\text { Closur } \\
\text { e Year }\end{array}$ & $\begin{array}{l}\text { Operatin } \\
\text { g Years }\end{array}$ & $\begin{array}{l}\text { Decommissio } \\
\text { ning End }\end{array}$ & $\begin{array}{l}\text { Decommissio } \\
\text { ning Duration }\end{array}$ & License Status & Works in the "Hot-Zone" \\
\hline Elk River & BWR & 22 & 1968 & 5 & 1974 & 6 & terminated & Segmentation of RPV/RVI \\
\hline Pathfinder & BWR & 59 & 1967 & 1 & 1993 & 26 & terminated & Deferred dismantling of the nuclear steam supply system \\
\hline Shoreham & BWR & 809 & 1986 & 0 & 1995 & 9 & terminated & \\
\hline Big Rock Point & BWR & 67 & 1997 & 35 & 2006 & 9 & ISFSI only & $\begin{array}{l}\text { RPV was removed in one piece after the internals were } \\
\text { segmented and stored on site as GTCC waste (Laraia 2012a, } \\
519 \text { ) }\end{array}$ \\
\hline Fort St. Vrain & HTGR & 330 & 1989 & 13 & 1997 & 8 & ISFSI only & $\begin{array}{l}\text { Westinghouse dismantled the RPV/RVI underwater (Fisher } \\
\text { 1998) }\end{array}$ \\
\hline CVTR & PHWR & 17 & 1967 & 4 & 2009 & 42 & terminated & n.a. \\
\hline Shippingport & PWR & 60 & 1982 & 25 & 1989 & 7 & terminated & $\begin{array}{l}\text { the RPV was taken out in one piece with the uncut internals } \\
\text { placed into the vessel and shipped to Hanford (Steele 1989) }\end{array}$ \\
\hline Maine Yankee & PWR & 860 & 1996 & 24 & 2005 & 9 & ISFSI only & $\begin{array}{l}\text { the segmented internals were put into the RPV, which } \\
\text { shipped to a disposal site (LaGuardia 2012, 519-22) }\end{array}$ \\
\hline Saxton & PWR & 25 & 1972 & 5 & 2005 & 33 & terminated & $\begin{array}{l}\text { RPV, steam generator, and pressurizer were removed, } \\
\text { packaged, and shipped to Barnwell (Williams and Carmel } \\
\text { 2000) }\end{array}$ \\
\hline Trojan & PWR & 1,095 & 1992 & 17 & 2005 & 13 & ISFSI only & $\begin{array}{l}\text { the reactor vessel was removed and transported to the } \\
\text { Hanford disposal site in } 1999 \text { (Cacuci 2010, 3026) }\end{array}$ \\
\hline Yankee NPS & PWR & 167 & 1991 & 31 & 2006 & 15 & ISFSI only & $\begin{array}{l}\text { the segmented vessel internals were put into the reactor } \\
\text { vessel and send to the Barnwell disposal site (LaGuardia } \\
2012,526 \text { ) }\end{array}$ \\
\hline Haddam Neck & PWR & 560 & 1996 & 29 & 2007 & 11 & ISFSI only & $\begin{array}{l}\text { The segmented vessel internals were put into the reactor } \\
\text { vessel and transported to the disposal site }\end{array}$ \\
\hline $\begin{array}{l}\text { Rancho Seco- } \\
1\end{array}$ & PWR & 873 & 1989 & 15 & 2009 & 20 & ISFSI only & $\begin{array}{l}\text { the vessel was segmented and shipped in sections for } \\
\text { disposal; the reactor vessel components were segmented and } \\
\text { the GTCC pieces stored in the ISFSI (LaGuardia 2012, 519- } \\
529 \text { ) }\end{array}$ \\
\hline
\end{tabular}

Table 15: Decommissioned Reactors in the U.S. (as of 2019).

Source: Own depiction and compilation.

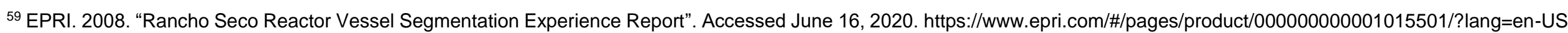




\subsubsection{Institutional system}

In the U.S., three federal bodies are involved in the process of decommissioning and radioactive waste management. The United States Department of Energy (DOE), the regulatory authority Nuclear Regulatory Commission (NRC), and the United States Environmental Protection Agency (EPA). The DOE was founded in 1977 with the goal to secure the economical and energy security of the US.; one of the main responsibilities of the DOE in regard of nuclear matters is the regulation of the handling of the radioactive inventory as well as spent nuclear fuel (OECD/NEA 2011). The mission of the NRC is to license and regulate the civilian use of byproduct, source, and special nuclear materials to ensure adequate protection of public health and safety, promote the common defense and security, and protect the environment. The mission of the EPA is to improve and preserve the quality of the environment by implementing and enforcing laws, setting environmental guidelines, monitoring pollution, performing research and promoting pollution prevention.

The licensees are responsible for decommissioning and can in general, choose between three different decommissioning strategies: immediate dismantling (called DECON), long-term enclosure (called SAFSTOR), and entombment of the reactor (called ENTOMB); a hybrid strategy is also allowed. The NRC imposes a time constraint on the decommissioning process, as decommissioning must be completed within 60 years of the plant ceasing operations. ${ }^{60}$

\subsubsection{Organizational models}

In general, decommissioning is the responsibility of the operators, who tender some of the work, especially in the hot-zone stage to specialized companies (e.g., Siempelkamp, Westinghouse). ${ }^{61} \mathrm{~A}$ new method that was recently used is the transfer of the decommissioning license from the operator to a waste management company with the goal to reap efficiency gains through the (co-)management of the decommissioning process by a company owning disposal facilities. This was done for the two Zion units in Illinois, where the operating license was transferred from Exelon to the waste management company EnergySolutions.

In December 2018, the Vermont Public Utility Commission approved the operating license transfer from Entergy to Northstar, mainly due to the accelerated decommissioning plan, as Northstar would start with decommissioning no later than 2021.62 The transfer also includes the dry storage facility. ${ }^{63}$ The deal includes the transfer of the decommissioning trust of US $\$ 571$ million as well as additional US $\$ 125$ million from Entergy. U.S. company Northstar has until now no large-scale decommissioning experience but has already signed a contract with Orano for the dismantling of the pressure vessel and

\footnotetext{
60 NRC. 2018. "Backgrounder on Decommissioning Nuclear Power Plants". Accessed June $16,2020$. https://www.nrc.gov/reading-rm/doc-collections/fact-sheets/decommissioning.html.

61 This section is largely based on the publications by the authors, mostly the annually updated chapter "Decommissioning Status Report" published in the World Nuclear Industry Status Report (Schneider et al. 2018, 2019).

62 John Dillon. 2018. "Vermont Yankee transfer approved, Northstar will decommission plant”. Accessed December 6, 2018. https://www.vpr.org/post/vermont-yankee-transfer-approved-northstar-will-decommission-plant.

63 U.S.NRC, "NRC Approves License Transfer for Vermont Yankee". Accessed October 12, 2018. https://www.nrc.gov/reading-rm/doc-collections/news/2018/18-047.pdf.
} 
internal structures. ${ }^{64}$ In June 2019, Duke Energy announced that it plans to sell the operating license for Crystal River-3, which is currently in LTE, to the Northstar and Orano joint venture. ${ }^{65}$

Another new actor on the US decommissioning market is the newly founded joint venture Comprehensive Decommissioning International, consisting of Holtec International (U.S. waste management company) and SNC-Lavalin (Canadian engineering company). The company plans to acquire licenses for additional plants in the coming years. The company plans the buy the first "commercial" reactor in the U.S., Oyster Creek, which was closed on September 17, 2018.

A total of six of the ten reactors currently being decommissioned have been sold to these new decommissioning companies (Schneider et al. 2019). At a first glance, the model seems to speed up decommissioning the process; efficiency gains through the (co-) management of the decommissioning process by a waste management company; especially in the case of EnergySolutions, which owns its own disposal facilities seem plausible, especially as this lowers the coordination needs. EnergySolutions can be considered as the first mover, when it integrated the role of general decommissioning manager in its portfolio. The company is close to complete the decommissioning of the Zion units on time. This organization model has since then drawn some attention and two new joint ventures have entered into direct competition and plan to buy several reactors.

However, none of these companies own disposal sites in the U.S. but Orano possesses specific knowhow and assets for hot-zone decommissioning works and Holtec is a major waste management company in the U.S. providing casks and building the independent spent fuel installations. On the other side of the coin, these models need to be examined more closely, as in most cases the decommissioning funds are also transferred to the new licensee. These developments are problematic because limited liability companies are only liable up to the value of their assets - in the event of an accident or other legal dispute. When the dismantling funds are exhausted, such a third party company could therefore declare bankruptcy and leave the bill for the taxpayer (Schlissel, Peterson, and Biewald 2002).

\subsubsection{United Kingdom}

\subsubsection{Decommissioning status}

Since 1977, 30 reactors or $4.7 \mathrm{GW}_{\mathrm{e}}$ have been shut down in the U.K., consisting for the larger part of the first generation of gas-cooled reactors (GCRs), the so-called Magnox line (26 reactors), but also the nuclear complex Sellafield. ${ }^{66}$ Up to today, the U.K. has not yet decommissioned one single reactor. On the contrary, the current strategy postpones the decommissioning end into the $22^{\text {nd }}$ century.

\subsubsection{Institutional system}

The first "nuclear" institution in the U.K. was the Nuclear Installations Act of 1965, which established the safety regulatory framework. In 2008, the Department of Energy and Climate Change (DECC) was

\footnotetext{
${ }^{64}$ McQuiston, Timothy. 2017. "French Firm Wins Vermont Yankee Reactor Dismantling Contract". Accessed August 18, 2018. https://vermontbiz.com/news/july/french-firm-wins-vermont-yankee-reactor-dismantling-contract.

65 WNN. "Accelerated decommissioning for Crystal River". Accessed May 31, 2019. http://world-nuclearnews.org/Articles/Accelerated-decommissioning-for-Crystal-River.

66 This section is largely based on publications by the authors, mainly Seidel and Wealer (2016), Wealer, Seidel, and Hirschhausen (2019), Schneider et al. (2018, 2019).
} 
formed and has ministerial responsibility for nuclear waste. In 2011, the ONR was established as an independent nuclear regulatory authority. In 2005, the Nuclear Decommissioning Authority (NDA) was established, the NDA sits beneath the DECC, to take over the planning and management of the UK's decommissioning of contaminated sites formerly operated by British Nuclear Fuels Plc. and the United Kingdom Atomic Energy Authority. The NDA is also responsible for implementing solutions for geological disposal and radioactive waste management (see MacKerron 2015 for more details on the institutions).

\subsubsection{Organizational model}

The Nuclear Decommissioning Authority is responsible for the decommissioning of the legacy fleet. The NDA's decommissioning strategy is long-term enclosure of the reactors: The biological shield is going to be sealed and the pressure vessel, the external pressure circuit, and steam generators stored within. Actual dismantling of the reactors will begin only 85 years after the initial closure (NDA 2016). Recent studies have shown, that the larger waste volumes stemming from decommissioning the reactor island will still not be suitable as disposal as LLW. In addition, the NDA has recognized that the reduction in decommissioning costs with the extension of the deferral period is largely offset by the increased costs of preparing and managing the long-term containment of the reactor (NDA 2016).

The 17 sites of the NDA estate were grouped into the following six Site License Companies (SLC): Magnox Limited, Sellafield Limited, Dounreay Site Restoration Limited (DSR), LLW Repository Limited, Springfield Fuels Limited, and Capenhurst Nuclear Services Limited. The NDA owns these sites and takes the role as the supervising and contracting authority and was turning the management over to contractors, the so-called Parent Body Organizations (PBO). The SLCs were the long-term shareholders of the sites. The idea was to periodically open the management of the SLCs to competition. These contracts were thought to be competitively tendered under EU public procurement law. The winner of these contracts acted as the Parent Body Organization (PBO). The PBO received the shares of the SLC, and organized the strategic management. The idea of opening up the work to private contractors was thought to increase the efficiency of the decommissioning process (MacKerron 2015). The task of the NDA was to define both the objective and the timing of the dismantling, so that the SLCs can determine how this outcome could best be achieved. Figure 10 gives an overview of the PBO model and the relationships between the NDA, PBO, SLC, and the regulatory authorities (ONR, Environment Agency (EA)). 


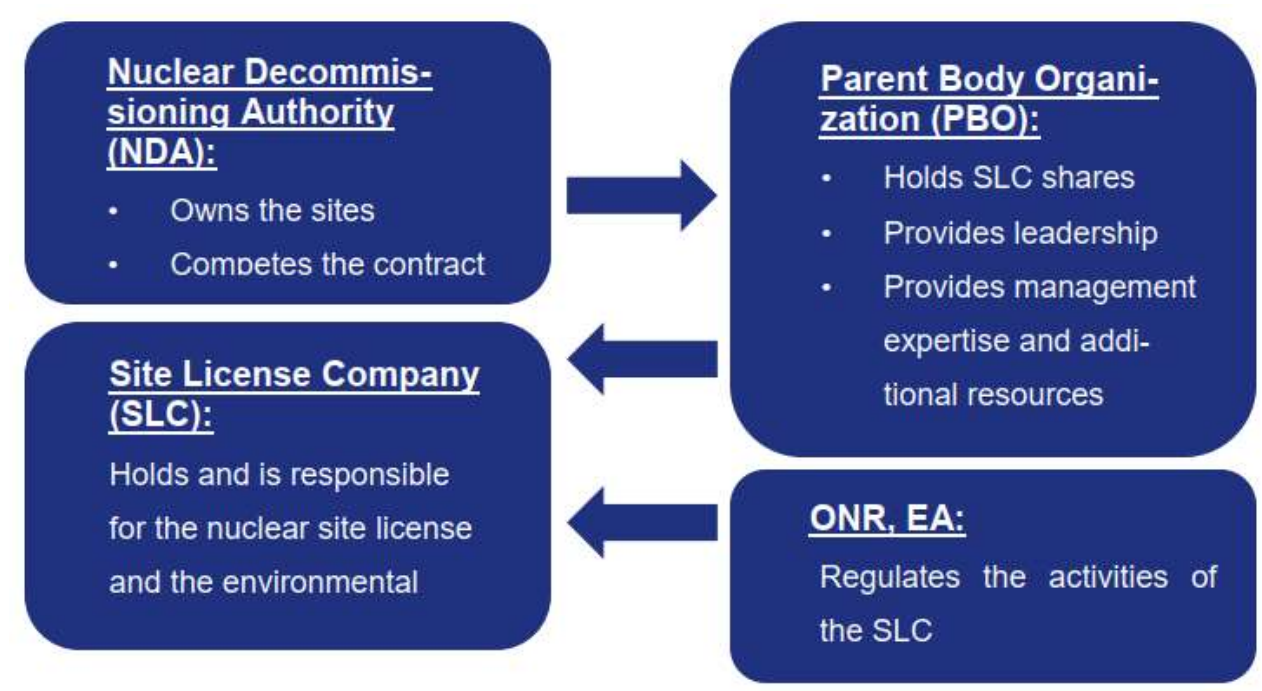

Figure 10: The PBO Model.

Source: Seidel and Wealer $(2016,88)$.

The Sellafield complex is operated by SLC Sellafield Ltd, which has been a wholly owned subsidiary of the NDA since 2016. An in-depth investigation revealed that the complex technical uncertainties at the Sellafield site are less suitable for the competitive PBO model. ${ }^{67}$ Their mission to retrieve nuclear waste from some of the oldest nuclear facilities in the world is expected to extend well into the $22^{\text {nd }}$ century, which requires long-term planning and not changing the strategic management every five years. Magnox Limited became the SLC of all the sites with Magnox reactors. The winner of the contract and PBO since 2014, was the Cavendish Fluor Partnership. The contract officially ended in 2019. Already in 2018, the NDA announced that it would drop the PBO model also for the Magnox sites and Magnox Ltd. became a subsidiary of the NDA, too. ${ }^{68}$ The House of Commons found that the NDA had completely failed in both procurement and management of the contract, which was one of the most important and valuable contracts awarded by the Government. The report concluded, that i.e. the procurement procedure was too complex and that the contract was awarded to the wrong bidder, which resulted in GBP 100 million in settlement of disputes. In addition, the amount of work was drastically underestimated. ${ }^{69}$

After trying to tender the decommissioning work of the legacy fleet competitively, decommissioning of the Magnox sites as well as Sellafield is now being handled by the NDA herself. Only the SLC Dounreay Site Restoration Limited is still wholly-owned by a private actor, the consortium Cavendish Dounreay Partnership consisting of Cavendish Nuclear, Jacobs and Amentum. Overall, introducing competition

67 NDA. "Explained: The New Model for Managing Sellafield". Accessed May 16, 2018. https://www.gov.uk/government/publications/new-model-for-managing-sellafield/explained-the-new-modelfor-managing-sellafield, accessed 16 May 2017.

68 NDA and Magnox Ltd. "Magnox Limited to Become a Nuclear Decommissioning Authority Subsidiary". Accessed July 8, 2018. https://www.gov.uk/government/news/magnox-limited-to-become-a-nuclear-decommissioningauthority-subsidiary.

69 Public Accounts Committee. "The Nuclear Decommissioning Authority's Magnox contract (Summary)." U.K. House Commons, https://publications.parliament.uk/pa/cm201719/cmselect/cmpubacc/461/46103.htm\#_idTextAnchor00 0 . 
into the decommissioning process has failed in the U.K.; for many reasons, such as the extreme complexity of the sites resulting from several decades of civil and (in the case of Sellafield) military nuclear activities and the very long timeframes. The NDA estimates that it will take another 110 years to complete the nuclear cleanup and disposal mission (NDA 2016).

\subsubsection{Germany}

\subsubsection{Decommissioning status}

The closure of Philipsburg at the end of 2019 increased the number of shutdown nuclear power plants to 30 reactors. ${ }^{70}$ Of these, only three were released from regulatory supervision (VAK Kahl, HDR Großwelzheim and Niederaichbach). Of these early prototype reactors, only the experimental nuclear power plant (VAK) Kahl was in operation for a longer period (24 years). Dismantling began immediately after the shutdown in 1988 and the site was released as a greenfield in 2010.

Of the commercial reactors only Würgassen and Gundremmingen-A have de facto completed the technical decommissioning process. Gundremmingen-A, which started decommissioning in 1983, has finished the "Ease-off-stage" in 2016. Both sites cannot be released from regulatory control as the buildings are used for further decommissioning works or interim storage of wastes (Wealer et al. 2015). Decommissioning of Stade (640 MW) was thought to be achieved by 2014, but ongoing difficulties due to unexpected contamination keeps delaying the project. The legacy fleet of the former German Democratic Republic (GDR) consisting of Rheinsberg and the five units of Greifswald are currently in the "Ease-Off-Stage". Although the hot-zone works were deferred for both sites: The six reactor pressure vessels, 17 steam generators and parts of the primary cooling system were transported to the "Interim Storage North", also operated by EWN. All plants shut down following the Fukushima accident in March 2011 have submitted their decommissioning proposal to the regulatory authority, but the German operators currently face several obstacles in order to be able to conclude the decommissioning process in a timely manner without excessive costs, among them insufficient numbers of transport and storage casks being produced to defuel the reactors. In addition, the early shutdown of reactors after the Moratorium caused a high number of "special" fuel rods—not completely burnt-up fuel-in the reactor core, for which no casks have yet been approved by the regulatory authority. The defueling and subsequent interim storage can not be achieved until the required casks are available. ${ }^{71}$ Table 16 shows the development in the decommissioning process since 2015 as of May 2019, not a lot of progress can be observed.

\footnotetext{
70 This section is largely based on publications by the authors, i.a. Wealer et al. (2015), Kunz et al. (2018), Wealer, Seidel und Hirschhausen (2019), Schneider et al. (2018, 2019), and the country case study on Germany in the World Nuclear Waste Report (Besnard et al. 2019).

${ }^{71}$ See Wealer et al. (2015) for a detailed survey of the German decommissioning process.
} 


\begin{tabular}{|c|c|c|c|}
\hline Germany & 2015 & May 2018 & May 2019 \\
\hline "Warm-up-stage" & 10 & 11 & 11 \\
\hline of which defueled & 0 & 2 & 6 \\
\hline "Hot-zone-stage" & 3 & 4 & 4 \\
\hline "Ease-off-stage" & 9 & 8 & 8 \\
\hline LTE & 2 & 1 & 1 \\
\hline Finished & 4 & 5 & 5 \\
\hline of which greenfield & 3 & 3 & 3 \\
\hline Shut-down reactors & 28 & 29 & 30 \\
\hline
\end{tabular}

Table 16: Current Status of Reactor Decommissioning in Germany (as of May 2018).

Source: Schneider et al. $(2018,2019)$.

\subsubsection{Institutional system}

The Fukushima accident in March 2011 had a catalytic effect on German nuclear policy. ${ }^{72}$ In 2014, the Commission on the Storage of High-Level Nuclear Waste (Repository Commission) was set up to audit the 2013 Repository Site Selection Act (StandAG) and develop recommendations for the site selection process. ${ }^{73}$ In parallel, the German government rearranged the responsibilities of its various agencies, aiming for more credibility and allowing for the rule of distance. In 2016, a new law transferred tasks previously undertaken by the public authority for radiation protection (BfS) to the public authority for the safety of nuclear disposal (BfE) and the new federal company for radioactive waste disposal (BGE). ${ }^{74}$ All the federal regulation, licensing, and supervisory tasks are bundled in the BfE; the operational tasks of site selection, building and operation of the DGDs was transferred to the BGE, which is also responsible for the construction of the Konrad mine (now scheduled to open in 2027, more than half a century after site selection). The ownership of the interim storage facilities for HLW was transferred to the federally owned company for interim storage (BGZ). In the coming years, the LILW storage facilities on the reactor sites will also be transferred to the public company.

In December 2016 the German parliament voted for a package on the Reform of Liability in Nuclear Waste Disposal, which allowed the utilities to transfer liability and financial responsibility for interim and final storage to the public. In return, an amount of 23.6bn EUR was transferred into a public fund. Utilities still remain liable for decommissioning and conditioning of the waste. ${ }^{75}$ As part of the reform, a transparency law was introduced which requires operators of nuclear power plants to report an overview of their remaining provisions for nuclear decommissioning and their available funds to finance future

\footnotetext{
72 This section is largely based on the publication by the author "country case study Germany" in the World Nuclear Waste Report (Besnard et al. 2019).

73 They define safety standards, assessment criteria and an adaptive procedure to enable revisions of decisions and to establish retrievability of the disposed waste. Furthermore, the site selection process is to be opened to all potential host rocks in Germany: claystone, rock salt and crystalline rock. Its final report recommends a three-phase process accompanied by public participation (Hocke and Kallenbach-Herbert 2015). The government implemented these recommendations in its 2017 revision of the StandAG and set an aspirational date to find a site by 2031.

${ }^{74}$ Government of Germany, Act on the reorganization of responsibility in nuclear waste management (Gesetz zur Neuordnung der Organisationsstruktur im Bereich der Endlagerung (BGBI., I, S. 1843 768/16).

75 German Parliament. 2017. Gesetz zur Transparenz über die Kosten der Stilllegung und des Rückbaus der Kernkraftwerke sowie der Verpackung radioaktiver Abfälle (Transparenzgesetz, „Law on transparency regarding the costs of decommissioning and dismantling nuclear power plants and packaging radioactive waste").
} 
costs of decommissioning to the Federal Office for Economic Affairs and Export Control (BAFA). In addition, the long-term enclosure of the plant is no longer an option and the reactors have to be dismantled as fast as possible (see Scherwath, Wealer, and Mendelevitch 2020 for more details)

\subsubsection{Organizational models}

There are two organizational models for the decommissioning of German nuclear power plants. The nuclear power plants of the former German Democratic Republic (GDR), consisting of Rheinsberg and the five Greifswald reactors are decommissioned by EWN GmbH (EWN Entsorgungswerk für Nuklearanlagen, formerly Energiewerke Nord). The sole shareholder of the company is the Federal Ministry of Finance. For the other commercial nuclear power plants, the energy companies are responsible for the decommissioning of their power plants and tender the work, especially the complex activities of the "hot-zone stage" to specialized nuclear companies (e.g. Areva for Würgassen and Stade, EWN for Obrigheim).

Experiences from past and ongoing decommissioning projects show that specialized companies are especially active in the hot-zone stage, where the reactor pressure vessel and the vessel internals are dismantled (Scherwath, Wealer, and Mendelevitch 2020). As this works constitute very complex and specific tasks, they can only be provided by a few nuclear firms as Westinghouse or Framatome. Some companies are also trying to achieve economies of scale: In January 2018, PreussenElektra awarded a decommissioning contract to Zerkon (a consortium led by the German utilities-owned waste management company GNS (PreussenElektra is the major shareholder of GNS with $48 \%$ of the shares) and Westinghouse Electric Sweden) to dismantle the RVI of its six plants (Schneider et al. 2018). Vattenfall awarded the contract for the dismantling of the RVI to a consortium of EWN and AREVA, with an option for the Krümmel plant. ${ }^{76} \mathrm{EnBW}$ awarded a contract for the dismantling of the RPV and RVI to a Westinghouse-led consortium with Nukem Technologies and GNS. ${ }^{77}$

The following companies have already worked in Germany or have concrete plans to enter the German market: Nukem Technologies; Framatome; EWN; Siempelkamp; GEH; Westinghouse; Babcock. Until now only EWN, Nukem, and Framatome have been active in the hot-zone-stage. The companies prefer to act in a consortium, bundling knowledge and sharing risks (Scherwath, Wealer, and Mendelevitch 2020). A special feature of the German market is the interconnection of service providers and operators, as the utilities - through the ownership of GNS - also act on the supply side of the market. Utilities-owned GNS was founded in 1977 and is providing transport, waste management, and disposal of waste. GNS is the main supplier of casks and developed the storage and transport casks CASTOR.

\footnotetext{
${ }^{76}$ AREVA. 2017. "AREVA-EWN Consortium to Dismantle the Reactor Pressure Vessel Internals of the Brunsbüttel Nuclear Power Plant," Accessed June 9, 2017. https://www.framatome.com/EN/businessnews-894/arevaewnconsortium-to-dismantle-the-rpv-internals-of-the-brunsbttel-nuclear-power-plant.html

77 Westinghouse. 2015. "Westinghouse-Led Consortium Awarded Segmentation of Reactor Pressure Vessel and Internals at Philippsburg Nuclear Power Plant Unit 1," 2015. http://www.westinghousenuclear.com/uknuclear/About/News/View/Westinghouse-led-Consortium-AwardedSegmentation-of-Reactor-Pressure-Vessel-and-Internals-at-Philippsburg-Nuclear-Power-Plant-Unit-1.
} 


\section{Conclusion}

In this paper, we provide an institutional economic analysis of the nuclear power industry, in the context of system good analysis. Nuclear power lends itself particularly for an interdisciplinary, technicalpolitical-economic analysis, due to the complex nature of the value-added chain, the socio-technical nature of the industry, and the complex economic questions involved. The aim of this paper is not to evaluate organizational models based on analysis parameters from economic theories (e.g. from New Institutional Economics: transaction costs, principal-agent theory), but rather to perform a positive analysis of the organizational and supply models for the value creation stages of the nuclear sector. Of special interest in this paper is the question of competition in the different value-added stages. For this, we look at the governance structure of the involved companies (state, private, semi-private), their degree of vertical integration, the market shares as well as the form of transaction, which can be done e.g. through the market or hierarchies, e.g. long-term contracts or vertical integration.

The main contribution of this paper is to bring together a detailed description of the theory of system goods, adopted from Beckers et al. (2012) and Gizzi (2016) in the context of institutional economics, with a very detailed assessment of nuclear power, perhaps the most complex system good one can imagine, and the nuclear power industry. With that goal, we identify ten sub-segments of the technical system, and identify relations and actors for some of them in detail. Thus, we are able to provide a comprehensive picture of the main institutional setting in sub-systems as diverse as the front-end (mining, enrichment, fuel fabrication), nuclear power plant construction and operation, and the back-end (decommissioning, interim storage, and final disposal). In addition, the paper addresses issues of reprocessing and of nuclear weapons. Clearly, nuclear power is the "child of scientific research and the

military" (Lévêque 2014, 212), the development of which follows an economies-of-scope-logic, with a joint production of military and civil products and services; however, this aspect is not addressed in detail in this paper.

The system good analysis of the different value-added stages shows a very complex good with a high number of interdependencies and interfaces, which need coordination. Based on the analysis, we derive some conclusions on the sector as such, and on the different sub-systems.

\section{NUCLEAR POWER AS COMPLEX SYSTEM GOOD}

Nuclear power is one of the, if not the most complex system good imaginable: The holistic description of the system good lets us identify a multitude of overlapping and interdependent value-added stages as well as a co-production of military and civil products and services. The different interdependent valueadded stages need coordination; this is why some major actors in the nuclear sector feature a high degree of vertical integration are active in nearly all value-added stages. Two state-controlled companies are highly vertically integrated: Rosatom with various subsidiaries and Orano/Framatome.

\section{THE VALUE-ADDED STAGE "FRONT-END" IS DOMINATED BY LONG-TERM CONTRACTS}

The uranium supply is currently far from resource limits. It is estimated that the 6 million tons of recoverable uranium deposits are equivalent to approximately 130 years of operation of the current global nuclear power plant fleet. The supply side of the uranium market is highly concentrated, with the top four producing mining companies (in that order) Kazatomprom, Orano, Cemaco, and Uranium One (Rosatom) serving about $50 \%$ of the uranium market. All four companies are state-controlled. Several 
mines are operated under joint ventures, for instance the Cigar Lake mine in Canada with the largest share of the world production, which is operated under a joint venture between Canadian Cameco and French Orano. Trade in uranium is made under long-term contracts; only about 20 percent of all uranium was sold on the spot market, and the remaining 80 percent under long-term contracts (Auzans et al. 2014), typically lasting for five years or in some cases ten years or more (Trieu, Savage, and Dwyer 1994).

Looking at the actors involved in the conversion services market, the four active companies Orano, Rosatom, CNNC, and Cameco are involved in the mining business. UF 6 conversion services can be bought on the spot market, but the majority of conversion supply is bought under long-term contracts between the nuclear utilities. Because of the inherent high risk of proliferation, only the nuclear weapon states have enrichment technologies on a commercial scale, with one exception, the Dutch-BritishGerman Urenco Company. The Russian State, through its public enterprise Tenex, has by far the largest enrichment capacity located at four enrichment plants, followed by the French state-controlled Orano. Due to the dual-use nature and the complex institutional environment, the majority of supply is conducted under long-term contracts, often with a duration of five or more years (OECD/NEA 2008, 64$65)$.

Nuclear fuel assemblies are highly engineered products that have to be adapted to the physical characteristics of the reactor. Due to this high specificity, a large part of the fuel fabrication companies either are reactor vendors, or owned by them. This holds true for the top three suppliers; Westinghouse and Framatome are major reactor vendors, while the Russian company TVEL, which produces the fuel for the Russian PWRs (VVER), is part of the Rosatom conglomerate. The market for LWR fuel has become more competitive lately, as several competing suppliers can now supply most fuel types; Russian TVEL is now able to manufacture Western PWR fuel, and Western companies can produce VVER fuel. As nuclear fuel assemblies are highly engineered products, the supply of nuclear fuel is generally based on long-term contracts.

The vertically integrated state-controlled companies Orano and Rosatom are involved in all the valueadded stages of the nuclear front-end through various subsidiaries. An emerging actor is Kazatomprom. Kazakhstan continuously increased its production year after year and overtook Canada and Australia in 2009 and has since then been the market leader in uranium mining with a market share of $22 \%$ in 2018 (Vestergaard 2015, 22). The company has also plans for vertical integration as it plans to add the elementary process of fuel fabrication into its portfolio, with a possible major customer being China to be an early major customer.

THE VALUE-ADDED STAGE CONSTRUCTION OF NUCLEAR POWER PLANTS IS CHARACTERIZED BY PLANNING DECISIONS, AND THIS ACTIVITY HAS NEVER BEEN ECONOMIC.

With regard to the decision to provide nuclear power plants, there is consensus on a centrally planned, state decision, since decentralized, private actors have no economic interest in investing in such a plant (Davis 2012; Joskow and Parsons 2012; D’haeseleer 2013; Wealer, Bauer, Göke, Christian von Hirschhausen, et al. 2019). Production can then be carried out by the state (integrated) or by awarding contracts to private actors in connection with regulatory agreements. Traditionally, governments can use public sector funds (especially for the introduction of nuclear) or have equity interests (Barkatullah and Ahmad 2017). In a few cases, the private sector was involved, by regulatory design, e.g. through cost- 
base regulation, but it never carried a major economic risk. Other forms of government financing mechanisms include additional cost recovery rates or surcharges on electricity sales (e.g., Vogtle project in Georgia, USA), the use of national funds, the creation of a government-led private bank, banks to finance infrastructure and asset pooling. Support and incentives for nuclear projects can also be provided by governments in the form of loan guarantees (e.g. Vogtle project), guaranteed long-term electricity contract agreements (e.g. Hinkley Point C) or with export credit agencies (e.g. the France Coface loan to the Finnish energy utility TVO for Olkiluto-3 in Finland) (Wealer, Bauer, Göke, Hirschhausen, et al. 2019).

The reactor market is highly concentrated and dominated by Rosatom with a market share of about 32 percent. The top three reactor vendor countries are Russia, China, and Korea, which share over 70 percent of the world market. The U.S. and Japan are the only two countries where privately owned companies construct reactors. The three top installers are in fact state-owned companies with a more "centralized planning" and less market oriented economic system with a close utility-regulatory agency connection. The close connection and cooperation between the reactor vendor and the state facilitates the export of reactors too, especially through Export Credit Agencies. In addition, Russia and China provide a strong government backed package including financing as a policy tool (Thomas 2019).

Today, production of large components will generally be subcontracted to specialist companies and built on a one-off basis, e.g. in Japan and China (Thomas 2010, 19-20). A high degree of localization can be observed in France, Japan, Korea, China, and Russia, while the U.K. and the U.S. have more or less abandoned localization and are dependent on imports for a large number of components, especially the reactor pressure vessel. The most critical components of a nuclear power plant are the ones attributed to the nuclear steam supply system, as they require heavy forgings. Apparently, the main very heavy forging capacities are located in Asia, the main actor being Japan Steel Works (JSW), which accounts for 80 percent of the world market for large forged components for NPPs and is contracted to supply Framatome. The supply chain for components for the nuclear island seems to be prone to constraints.

In general, the complex nature of a nuclear power plant requires a considerable degree of "after sales" service from the vendor (OECD/NEA 2008, 31). In most cases, the reactor vendor also supplies fuel services, as the majority of the major vendors (e.g. Westinghouse, Rosatom, Framatome) have integrated fuel companies into their firm structure. Most reactor vendors also provide maintenance and replacement services during the reactor's lifetime.

\section{At the VALUE-ADDED STAGE „DECOMMISSIONING“, APPROACHES TO INTRODUCE COMPETITION AND INCENTIVE REGULATION HAVE SO FAR NOT BEEN SUCCESSFUL.}

The decommissioning of nuclear power plants is still largely unexplored, but of increasing importance. Competitive approaches to dismantling have had little effect so far. The U.K. tried to tender the decommissioning work of its legacy fleet competitively but this failed. Now, the National Decommissioning Authority itself handles decommissioning of the Magnox sites as well as Sellafield. Overall, introducing competition into the decommissioning process was unsuccessful for many reasons, such as the extreme complexity of the sites resulting from several decades of civil and (in the case of Sellafield) military nuclear activities and the very long timeframes. 
In the U.S., some market competition is emerging as mostly waste management companies are entering the market and buying nuclear power plants for large-scale decommissioning trying to reap economies of scale. A total of six of the ten reactors currently being decommissioned have been sold to these new decommissioning companies (Schneider et al. 2019). At a first glance, the model seems to speed up decommissioning the process; efficiency gains through the (co-) management of the decommissioning process by a waste management company. This is especially the case of EnergySolutions, which owns its own disposal facilities, which lowers the coordination needs and transaction costs. This organization model has since then drawn some attention and two new joint ventures have entered into direct competition and plan to buy several reactors. These developments need further analysis as limited liability companies are only liable up to the value of their assets - in the event of an accident or other legal dispute. When the dismantling funds are exhausted, such a third party company could therefore declare bankruptcy and leave the bill for the taxpayer (Schlissel, Peterson, and Biewald 2002).

In Germany, the utilities are still responsible for decommissioning of their power plants. They tender the work, especially the complex activities of the "hot-zone stage" to specialized nuclear companies (e.g. Areva for Würgassen and Stade, EWN for Obrigheim). Some companies are also trying to achieve economies of scale: In January 2018, PreussenElektra awarded a decommissioning contract to Zerkon, a GNS and Westinghouse Electric Sweden consortium, to dismantle the vessel internals of its six plants. A special feature of the German market is the interconnection of service providers and operators, as the utilities - through the ownership of GNS - also act on the supply side of the waste management services market. However, this does not resolve issues of long-term risk allocation and financing.

\section{THE STAGE "FINAL DISPOSAL" IS THE MOST COMPLEX ONE, AND FEATURES MULTIPLE PRINCIPAL-AGENT CHALLENGES.}

Waste disposal facilities are generally constructed and operated by state agencies or public companies. In a very few cases, the waste management organization is owned by the utilities (e.g., Sweden, Finland). In the U.S., some private companies are operating low-level waste disposal facilities, among them EnergySolutions, a major nuclear waste management company. The final disposal of high-level waste is normally the responsibility of a special government agency. Although again i.e. Sweden and Finland are exceptions to this. As there is still no disposal facility available worldwide, interim storage issues are coming to the fore. Interim storage is often the scope of the utilities, while the disposal is dominated by the state worldwide. This places special demands on the regulators due to multiple principal-agent problems between the utility responsible for conditioning (and storing) of the waste and the state agency taking over the waste for final disposal. As the state has to provide, in most cases, the disposal facility for HLW, there is no real competition in this value-added stage. There is some competition with regard to specialized waste management companies providing casks or conditioning services. Here, the main actors are the German utilities-owned GNS (Gesellschaft für Nuklear-Service $\mathrm{mbH}$ ), which produces the CASTOR casks, French Orano, and US Holtec International, which are also active in the value-added stage of decommissioning.

As reprocessing means the extraction of plutonium, there is no real "civil" or "private" provider of reprocessing services and all reprocessing service providers are state-controlled. Since 2018, La Hague in France operated by Orano is the last commercial reprocessing plant in Western Europe. Orano has a monopoly position and has thus with the exception of disposal of nuclear waste services fully 
integrated the nuclear front- and back-end in its firm. The same holds true for Atomenergoprom, part of Rosatom. Reprocessing contracts are settled through long-term contracts.

Clearly, the nuclear industry lends itself well for institutional economic analysis, including reflections on the industrial economic structure, and the role of competition and regulation. The latter questions have so far played a negligible role in the current economic policy debate about nuclear power, and should be given greater emphasis in further economic policy research. In this paper, we have identified specific regulatory challenges for the back-end, in particular upstream and downstream of the decommissioning of reactor. More in-depth research is required to foster independent expertise on these and other matters of the complex system good nuclear power.

\section{References}

Acheson-Lilienthal Report. 1946. "A Report on the International Control of Atomic Energy." Prepared for the Secretary of State's Committee on Atomic Energy. Washington, D.C.

acir. 1987. "The Organization Of Local Public Economies." Washington D.C.: Advisory Commission on Intergovernmental Relations.

Aumann, Robert J. 1972. Values of Non-Atomic Games. Princetion, NJ: Princeton University Press.

Auzans, Aris, Erich A. Schneider, Robert Flanagan, and Alan H. Tkaczyk. 2014. "A Mine-Based Uranium Market Clearing Model." Energies 7 (11): 7673-7693.

Barkatullah, Nadira, and Ali Ahmad. 2017. "Current Status and Emerging Trends in Financing Nuclear Power Projects." Energy Strategy Reviews 18 (Supplement C): 127-140.

Beckers, Thorsten, Florian Gizzi, and Klaus Jäkel. 2012. "Ein Untersuchungsansatz für Systemgüter: Einordnung, Darstellung, Vorgehen bei der Anwendung." 2012-01. WIP-Working Paper. Berlin: Technische Universität Berlin.

Beckers, Thorsten, Jürgen Kühling, and Jan Peter Klatt. 2011. Institutionelle Lösungen für die Finanzierung der Bundesfernstraßen - Eine Analyse aus ökonomischer und juristischer Sicht. München: ADAC e.V.

Besnard, Manon, Marcos Buser, Ian Fairlie, Gordon MacKerron, Allison Macfarlane, Eszter Matyas, Yves Marignac, Edvard Sequens, Johan Swahn, and Ben Wealer. 2019. "The World Nuclear Waste Report. Focus Europe." Berlin, Brussels.

Bleise, A., P.R. Danesi, and W. Burkart. 2003. "Properties, Use and Health Effects of Depleted Uranium (DU): A General Overview." Journal of Environmental Radioactivity 64: 93-112.

Bodansky, David. 2004. Nuclear Energy: Principles, Practices, and Prospects. 2nd ed. New York: Springer.

Bracken, Paul. 2012. The Second Nuclear Age - Strategy, Danger, and the New Power Politics. New York, USA: Times Books - Henry Holt and Company, LLC.

Bradford, Peter A. 2013. "How to Close the US Nuclear Industry: Do Nothing." Bulletin of the Atomic Scientists 69 (2): 12-21.

Brunnengräber, Achim, and Maria Rosaria Di Nucci. 2019. Conflicts, Participation and Acceptability in Nuclear Waste Governance: An International Comparison. Volume III. Wiesbaden: Springer VS.

Brunnengräber, Achim, Maria Rosaria Di Nucci, Ana María Isidoro Losada, Lutz Mez, and Miranda A. Schreurs, eds. 2018. Challenges of Nuclear Waste Governance. An International Comparison Volume II. Wiesbaden, Germany: Springer VS.

Brunnengräber, Achim, Maria Rosaria Di Nucci, Ana Maria Isidoro Losada, Lutz Mez, and Miranda A. Schreurs. 2015. Nuclear Waste Governance: An International Comparison. Berlin, Germany: Springer.

Cacuci, D. G., ed. 2010. Handbook of Nuclear Engineering. Springer Reference. New York; London: Springer. 
Clemmer, Steve, Jeremy Richardson, Sandra Sattler, and Dave Lochbaum. 2018. "The Nuclear Power Dilemma Declining Profits, Plant Closures, and the Threat of Rising Carbon Emissions." Cambridge, MA: Union of Concerned Scientists.

Coase, Ronald H. 1937. "The Nature of the Firm." Economica 4 (16): 386-405.

Cohn, Steve. 1990. "The Political Economy of Nuclear Power (1945 - 1990): The Rise and Fall of an Official Technology." Journal of Economic Issues 24 (3): 781-811.

Considine, Timothy J. 2019. "The Market Impacts of US Uranium Import Quotas." Resources Policy 63 (October): 101445.

Cox, Emily, Phil Johnstone, and Andy Stirling. 2016. "Understanding the Intensity of UK Policy Commitments to Nuclear Power." SPRU Working Paper Series 2016-16. Sussex, UK: University of Sussex.

Cumo, Maurizio. 2010. "Decommissioning of Nuclear Plants." In Handbook of Nuclear Engineering, edited by Dan Gabriel Cacuci, 2010th ed., 3000-3252. New York ; London: Springer.

Davis, Lucas W. 2012. "Prospects for Nuclear Power." Journal of Economic Perspectives 26 (1): 49-66.

Delaney, Edward G. 1985. "Decommissioning US DOE Nuclear Facilities." IAEA Bulletin. Vienna, Austria: International Atomic Energy Agency.

D'haeseleer, William D. 2013. "Synthesis on the Economics of Nuclear Energy - Study for the European Commission, DG Energy." Final Report. Leuven: KU Leuven.

Diekmann, Jochen. 2011. "Verstärkte Haftung und Deckungsvorsorge für Schäden nuklearer Unfälle Notwendige Schritte zur Internalisierung externer Effekte." Zeitschrift für Umweltpolitik und Umweltrecht 34 (2).

Drupady, Ira Martina. 2019. "Emerging Nuclear Vendors in the Newcomer Export Market: Strategic Considerations." The Journal of World Energy Law \& Business 12 (1): 4-20.

Energy Futures Initiative. 2017. "The U.S. Nuclear Energy Enterprise: A Key National Security Enabler." Washington DC, USA: Energy Futures Initiative.

Fairlie, Ian. 2009. "Depleted Uranium: Properties, Military Use and Health Risks." Medicine, Conflict and Survival 25 (1): 41-64.

Fisher, M. 1998. "Fort St. Vrain Decommissioning Project." Denver, CO, USA: Public Service Company of Colorado.

Furubotn, Eirik Grundtvig, and Rudolf Richter. 2005. Institutions and Economic Theory: The Contribution of the New Institutional Economics. 2nd ed. Economics, Cognition, and Society. Ann Arbor: University of Michigan Press.

Giannardi, Cristina, and Daniele Dominici. 2003. "Military Use of Depleted Uranium: Assessment of Prolonged Population Exposure." Journal of Environmental Radioactivity 64: 227-236.

Gizzi, Florian. 2016. "Implementierung komplexer Systemgüter - ein methodischer Ansatz für ökonomische Untersuchungen und seine Anwendung auf Verkehrstelematiksysteme für die Straße." Dissertation, Technische Universität Berlin.

Hayek, F. A. von. 1945. "The Use of Knowledge in Society." American Economic Review 35 (4): 519 530.

Hocke, Peter, and Beate Kallenbach-Herbert. 2015. "Always the Same Old Story? Nuclear Waste Governance in Germany." In Nuclear Waste Governance. An International Comparison, edited by Lutz Mez and Achim Brunnengräber, 177-201. Wiesbaden: Springer VS.

Homberg, Frank, Mathieu Pavageau, and Mycle Schneider. 1997. "Cogema - La Hague. The Waste Production Techniques." Paris, France: Greenpeace International.

Hyatt, Neil C. 2017. "Plutonium Management Policy in the United Kingdom: The Need for a Dual Track Strategy." Energy Policy 101 (February): 303-309.

IAEA. 2002. "Factors Determining the Long Term Back End Nuclear Fuel Cycle Strategy and Future Nuclear Systems." IAEA-TECDOC-1286. Vienna: International Atomic Energy Agency.

2007a. "Categorizing Operational Radioactive Wastes." IAEA-TECDOC 1538. Vienna, Austria: International Atomic Energy Agency.

2007b. "Estimation of Global Inventories of Radioactive Waste and Other Radioactive Materials." IAEA-TECDOC 1591. Vienna, Austria: International Atomic Energy Agency.

2007c. "IAEA Safety Glossary - Terminology Used in Nuclear Safety and Radiation Protection." Vienna, Austria: International Atomic Energy Agency.

2009. "Classification of Radioactive Waste." IAEA Safety Standards GSG-1. Vienna, Austria: International Atomic Energy Agency. 
Ichord, Robert F., and Bart Oosterveld. 2019. "The Value of the US Nuclear Power Complex to US National Security." Washington DC, USA: Atlantic Council.

Irrek, Wolfgang. 2019. "Financing Nuclear Decommissioning." In The Technological and Economic Future of Nuclear Power, edited by Reinhard Haas, Lutz Mez, and Amela Ajanovic, 139-168. Energiepolitik Und Klimaschutz. Energy Policy and Climate Protection. Wiesbaden: Springer VS.

Jacobson, Mark Z. 2019. "Evaluation of Nuclear Power as a Proposed Solution to Global Warming, Air Pollution, and Energy Security." In 100\% Clean, Renewable Energy and Storage for Everything, (in press). Cambridge: Cambridge University Press.

Jewell, Jessica, Marta Vetier, and Daniel Garcia-Cabrera. 2019. "The International Technological Nuclear Cooperation Landscape: A New Dataset and Network Analysis." Energy Policy 128 (May): 838-852.

Joskow, Paul L., and John E. Parsons. 2012. "The Future of Nuclear Power After Fukushima." Economics of Energy \& Environmental Policy 1 (2): 99-113.

Kåberger, Tomas. 2019. "Economic Management of Future Nuclear Accidents." In The Technological and Economic Future of Nuclear Power, edited by Reihard Haas, Lutz Mez, and Amela Ajanovic, 211-220. Energy Policy and Climate Protection. Wiesbaden: Springer VS.

Klatt, Jan Peter. 2011. Eine institutionenökonomische Analyse von Finanzierungslösungen für die Bundesfernstraßen. Wettbewerb und Regulierung von Märkten und Unternehmen 15. BadenBaden: Nomos.

Kunz, Friedrich, Felix Reitz, Christian von Hirschhausen, and Ben Wealer. 2018. "Nuclear Power: Effects of Plant Closures on Electricity Markets and Remaining Challenges." In Energiewende "Made in Germany": Low Carbon Electricity Sector Reform in the European Context, edited by Christian von Hirschhausen, Clemens Gerbaulet, Claudia Kemfert, Casimir Lorenz, and PaoYu Oei. Cham, Switzerland: Springer Nature Switzerland AG.

LaGuardia, T. S. 2012. "Decommissioning of Western-Type Light-Water Nuclear Reactors (LWRs)." In Nuclear Decommissioning, edited by Michele Laraia, 513-563. Woodhead Publishing Series in Energy. Woodhead Publishing.

LaGuardia, T. S., and K. C. Murphy. 2012. "Financing and Economics of Nuclear Facility Decommissioning." In Nuclear Decommissioning - Planning, Execution and International Experience, edited by Michele Laraia, 49-86. Oxford, Cambridge, Philadelphia, New Dehli: Woodhead Publishing.

Laraia, Michele, ed. 2012a. Nuclear Decommissioning: Planning, Execution and International Experience. Oxford, Cambridge, Philadelphia, New Dehli: Woodhead Publishing.

2012b. "Overview of Nuclear Decommissioning Principles and Approaches." In Nuclear Decommissioning - Planning, Execution and International Experience, edited by Michele Laraia, 33-48. Oxford, Cambridge, Philadelphia, New Dehli: Woodhead Publishing.

2012c. "Reuse and Redevelopment of Decommissioned Nuclear Sites: Strategies and Lessons Learned." In Nuclear Decommissioning - Planning, Execution and International Experience, edited by Michele Laraia, 475-510. Oxford, Cambridge, Philadelphia, New Dehli: Woodhead Publishing.

Lévêque, François. 2014. The Economics and Uncertainties of Nuclear Power. Cambridge, UK: Cambridge University Press.

Lovins, Amory B. 2013. "The Economics of a US Civilian Nuclear Phase-Out." Bulletin of the Atomic Scientists 69 (2): 44-65.

Lovins, Amory B., L. Hunter Lovins, and Leonard Ross. 1980. "Nuclear Power and Nuclear Bombs." Foreign Affairs 58 (5): 1137-1177.

MacKerron, Gordon. 2015. "Multiple Challenges - Nuclear Waste Governance in the United Kingdom." In Nuclear Waste Governance. An International Comparison, edited by Lutz Mez and Achim Brunnengräber, 101-116. Wiesbaden: Springer VS.

Mendelevitch, Roman, and Thanh Thien Dang. 2016. "Nuclear Power and the Uranium Market: Are Reserves and Resources Sufficient?" DIW Roundup 98. Berlin, Deutschland: DIW Berlin Deutsches Institut für Wirtschaftsforschung.

Meyer, Bettina. 2012. "Externe Kosten der Atomenergie und Reformvorschläge zum Atomhaftungsrecht - Dokumentation von Annahmen, Methoden und Ergebnissen." Hintergrundpapier im Rahmen des Projekts "Was Strom wirklich kostet" im Auftrag von Greenpeace Energy e.V. und Bundesverband WindEnergie. Berlin, Germany. 
Mez, Lutz. 2012. "Nuclear Energy-Any Solution for Sustainability and Climate Protection?" Energy Policy 48 (September): 56-63.

Monnet, Antoine, Sophie Gabriel, and Jacques Percebois. 2017. "Analysis of the Long-Term Availability of Uranium: The Influence of Dynamic Constraints and Market Competition." Energy Policy 105 (June): 98-107.

Murphie, William. 1991. "Grenfield Decommissioning at Shippingport: Cost Management and Experience." Energy Journal 12 (Special Nuclear Decommissioning Issue): 119-132.

Nakano, Jane. 2020. "The Changing Geopolitics of Nuclear Energy." Washington D.C.: Center for Strategic \& International Studies.

Nash, John F. 1950. "Equilibrium Points in N-Person Games." Proceedings of the National Academy of Sciences of the United States of America 36 (1): 48-49.

NDA. 2016. "Strategy - Effective from April 2016." Cumbria: Nuclear Decommissioning Authority.

NEA, and IAEA. 2018. "Uranium 2018: Resources, Production and Demand." Paris: Nuclear Energy Agency / Organisation for Economic Co-operation and Development.

Neles, Julia Mareike, and Gerhard Schmidt. 2012. "Urangewinnung - Von der Mine bis ins Kraftwerk." In Kernenergie: eine Technik für die Zukunft?, edited by Julia Mareike Neles and Christoph Pistner, 143-159. Technik im Fokus. Berlin: Springer Vieweg.

North, Douglass C. 1990. Institutions, Institutional Change and Economic Performance. Cambridge: Cambridge University Press.

OECD/NEA. 2008. Market Competition in the Nuclear Industry. Paris: OECD Publishing. . 2011. "Radioactive Waste Management and Decomissioning in the United States of America Report." 2011.

— 2016. "Costs of Decommissioning Nuclear Power Plants." Paris: Nuclear Energy Agency / Organisation for Economic Co-operation and Development.

Ostrom, Elinor. 2005. Understanding Institutional Diversity. Princeton: Princeton University Press.

Ostrom, Elinor, Larry Schroeder, and Susan Wynne. 1993. Institutional Incentives and Sustainable Development - Infrastructure Policies in Perspective. Boulder, Oxford: Westview Press.

Owen, A.D. 1983. "The Economics of Uranium Demand." Resource Policy 9 (2): 110-121.

Papp, Mick, Tim Milner, and Bart Slimp. 2002. "Big Rock Bows Out." Nuclear Engineering International Magazine.

Pittman, F. K. 1961. "Nuclear Power Development in the United States." Science 133 (3464): 15661572.

Radkau, Joachim. 1983. Aufstieg und Krise der deutschen Atomwirtschaft 1945-1975: Verdrängte Alternativen in der Kerntechnik und der Ursprung der nuklearen Kontroverse. Reinbek bei Hamburg, Germany: Rowohlt.

Rhodes, Richard, ed. 2012. The Making of the Atomic Bomb. 25th anniversary ed. New York, USA: Simon \& Schuster Paperbacks.

Rooney, Matthew, William J. Nuttall, and Nikolaos Kazantzis. 2015. "A Dynamic Model of the Global Uranium Market and the Nuclear Fuel Cycle." Resources Policy 43 (March): 50-60.

Rosner, Robert, and Rebecca Lordan. 2014. "Why America Should Move towards Dry Cask Consolidated Interim Storage of Used Nuclear Fuel." Bulletin of the Atomic Scientists 70 (6): 48-62.

Rothwell, Geoffrey. 2009. "Market Power in Uranium Enrichment." Science \& Global Security 17 (2): 132-154.

2016. Economics of Nuclear Power. London, UK: Routledge.

Schelling, Thomas C. 1960. Strategy of Conflict. Cambridge, USA: Harvard University Press.

Scherwath, Tim, Ben Wealer, and Roman Mendelevitch. 2020. "Nuclear Decommissioning after the German Nuclear Phase-Out an Integrated View on New Regulations and Nuclear Logistics." Energy Policy 137 (February 2020): 111125.

Schlissel, D., P. Peterson, and B. Biewald. 2002. "Financial Insecurity: The Increasing Use of Limited Liability Companies and Multi-Tiered Holding Companies to Own Nuclear Power Plants." Cambridge, MA, USA: Synapse Energy Economics; STAR Foundation Riverkeeper, Inc.

Schneider, Mycle, Antony Froggatt, Julie Hazemann, Tadahiro Katsuta, Amory B. Lovins, M. V. Ramana, Christian von Hirschhausen, and Ben Wealer. 2019. "World Nuclear Industry Status Report 2019." Paris, London: Mycle Schneider Consulting. 
Schneider, Mycle, Antony Froggatt, Phil Johnstone, Andy Stirling, Tadahiro Katsuta, M. V. Ramana, Christian von Hirschhausen, Ben Wealer, Agnès Stienne, and Julie Hazemann. 2018. "World Nuclear Industry Status Report 2018." Paris, London: Mycle Schneider Consulting.

Schulze, William D., David S. Brookshire, and Todd Sandler. 1981. "The Social Rate of Discount for Nuclear Waste Storage: Economics or Ethics?" Natural Resources Journal 21 (4): 811-832.

Seidel, Jan-Paul, and Ben Wealer. 2016. "Decommissioning of Nuclear Power Plants and Storage of Radioactive Waste - An International Comparison of Organizational Models." Master thesis, Berlin Institute of Technology. Berlin, Germany: Berlin Institute of Technology.

Sorge, Lars, Claudia Kemfert, Christian von Hirschhausen, and Ben Wealer. 2020. "Nuclear Power Worldwide: Development Plans in Newcomer Countries Negligible." DIW Weekly Report 11/2020: 163-172.

Sovacool, Benjamin K., and Alex Funk. 2013. "Wrestling with the Hydra of Nuclear Waste Storage in the United States." The Electricity Journal 26 (2): 67-78.

Steele, Karen Dorn. 1989. "Hanford: America's Nuclear Graveyard." Bulletin of the Atomic Scientists 45 (8): 14-23.

Thierfeldt, S., and F. Schartmann. 2009. Stilllegung und Rückbau kerntechnischer Anlagen. 3rd ed. Aachen: Brenk Systemplanung.

Thomas, Stephen. 1988. The Realities of Nuclear Power: International Economic and Regulatory Experience. Cambridge University Press.

2010. "The Economics of Nuclear Power: An Update." Brussels: Heinrich-Böll-Stiftung.

2017. "China's Nuclear Export Drive: Trojan Horse or Marshall Plan?" Energy Policy 101 (Supplement C): 683-691.

2018. "Russia's Nuclear Export Programme." Energy Policy 121 (October): 236-247.

2019. "Is It the End of the Line for Light Water Reactor Technology or Can China and Russia Save the Day?" Energy Policy 125 (February): 216-226.

Tompkins, Betsy. 2006. "Big Rock Point: From Groundbreaking to Greenfield." Nuclear News 49 (12): 36-43.

Trieu, Luan Ho, Eric Savage, and Gavan Dwyer. 1994. "A Model of the World Uranium Market." Energy Policy 22 (4): 317-329.

University of Chicago. 2004. "The Economic Future of Nuclear Power." Chicago, IL: University of Chicago.

Vestergaard, Cindy. 2015. "Governing Uranium Globally.” DIIS Report. Copenhagen, Denmark: Danish Institute for International Studies.

Volk, Rebekka, Felix Hübner, Tobias Hünlich, and Frank Schultmann. 2019. "The Future of Nuclear Decommissioning - A Worldwide Market Potential Study." Energy Policy 124 (January): 226261.

von Hirschhausen, Christian von. 2017. "Nuclear Power in the 21st Century - An Assessment (Part I)." DIW Discussion Paper 1700. Berlin, Germany: DIW Berlin.

Wealer, Ben, Simon Bauer, Leonard Göke, Christian von Hirschhausen, and Claudia Kemfert. 2019. "High-Priced and Dangerous: Nuclear Power Is Not an Option for the Climate-Friendly Energy Mix." DIW Weekly Report 30/2019: 235-243.

Wealer, Ben, Simon Bauer, Leonard Göke, Christian von Hirschhausen, and Claudia Kemfert. 2019. "Economics of Nuclear Power Plant Investment - Monte Carlo Simulations of Generation III/II+ Investment Projects." DIW Discussion Paper 1833. Berlin, Germany: DIW Berlin.

Wealer, Ben, Simon Bauer, Nicolas Landry, Hannah Seiß, and Christian von Hirschhausen. 2018. "Nuclear Power Reactors Worldwide - Technology Developments, Diffusion Patterns, and Country-by-Country Analysis of Implementation (1951-2017)." Data Documentation 93. Berlin: DIW Berlin, TU Berlin.

Wealer, Ben, Victoria Czempinski, Christian von Hirschhausen, and Sebastian Wegel. 2017. "Nuclear Energy Policy in the United States: Between Rocks and Hard Places." IAEE Energy Forum, no. Second Quarter 2017: 25-29.

Wealer, Ben, Clemens Gerbaulet, Christian von Hirschhausen, and Jan Paul Seidel. 2015. "Stand und Perspektiven des Rückbaus von Kernkraftwerken in Deutschland (»Rückbau-Monitoring 2015«)." Data Documentation 81. Berlin, Germany: DIW Berlin, TU Berlin.

Wealer, Ben, Jan Paul Seidel, and Christian von Hirschhausen. 2019. "Decommissioning of Nuclear Power Plants and Storage of Nuclear Waste: Experiences from Germany, France, and the U.K." 
In The Technological and Economic Future of Nuclear Power, edited by Reinhard Haas, Lutz Mez, and Amela Ajanovic, 261-286. Wiesbaden: Springer VS.

Williams, Michael S., and Perry G. Carmel. 2000. "What You Don't Know Can Hurt You!' A Review of 'Lessons Learned' from the Saxton Nuclear Experimental Facility - Historical Site Assessment." In WM'00 Conference. Tucson, AZ, USA.

Williamson, Oliver E. 1985. The Economic Institutions of Capitalism: Firms, Markets, Relational Contracting. New York: Free Press.

- 2000. "The New Institutional Economics: Taking Stock, Looking Ahead." Journal of Economic Literature 38 (3): 595-613.

WNA. 2016. "The World Nuclear Supply Chain: Outlook 2035." London: World Nuclear Association.

Wuppertal Institut. 2007. "Comparison among Different Decommissioning Funds Methodologies for Nuclear Installations." Brussels-Luxembourg: EC-EAEC. 